\title{
Chemometric perspectives on plankton community responses to natural iron fertilisation over and downstream of the Kerguelen Plateau in the Southern Ocean
}

\author{
T. W. Trull ${ }^{1,2}$, D. M. Davies ${ }^{1,2}$, F. Dehairs ${ }^{3}$, A.-J. Cavagna ${ }^{4}$, M. Lasbleiz ${ }^{5}$, E. C. Laurenceau-Cornec ${ }^{1,2,3}$, F. d'Ovidio $^{6}$, \\ F. Planchon ${ }^{7}$, K. Leblanc ${ }^{5}$, B. Quéguiner ${ }^{5}$, and S. Blain ${ }^{8,9}$ \\ ${ }^{1}$ CSIRO Marine and Atmospheric Research, Hobart, Tasmania, Australia \\ ${ }^{2}$ Antarctic Climate and Ecosystems Cooperative Research Centre, Hobart, Tasmania, Australia \\ ${ }^{3}$ Institute for Marine and Antarctic Studies, University of Tasmania, Hobart, Tasmania, Australia \\ ${ }^{4}$ Analytical, Environmental and Geochemistry; Earth Sciences Research Group, Vrije Universiteit Brussel, Belgium \\ ${ }^{5}$ Aix-Marseille Université and Université de Toulon, Marseille, France \\ ${ }^{6}$ LOCEAN-IPSL, Université Pierre et Marie Curie, Paris, France \\ ${ }^{7}$ Laboratoire des Sciences de l'Environnement Marin (LEMAR), Université de Brest, IUEM, Plouzané, France \\ ${ }^{8}$ Sorbonne Universités, UPMC Univ Paris 06, UMR7621, Laboratoire d'Océanographie Microbienne, Observatoire \\ Océanologique, 66650 Banyuls/mer, France \\ ${ }^{9}$ CNRS, Laboratoire d'Océanographie Microbienne, Observatoire Océanologique, 66650 Banyuls/mer, France
}

Correspondence to: T. W. Trull (tom.trull@csiro.au)

Received: 29 August 2014 - Published in Biogeosciences Discuss.: 23 September 2014

Revised: 8 January 2015 - Accepted: 8 January 2015 - Published: 18 February 2015

\begin{abstract}
We examined phytoplankton community responses to natural iron fertilisation at 32 sites over and downstream from the Kerguelen Plateau in the Southern Ocean during the austral spring bloom in October-November 2011. The community structure was estimated from chemical and isotopic measurements (particulate organic carbon - POC; ${ }^{13} \mathrm{C}-\mathrm{POC}$; particulate nitrogen - PN; ${ }^{15} \mathrm{~N}-\mathrm{PN}$; and biogenic silica - BSi) on size-fractionated samples from surface waters $(300,210,50,20,5$, and $1 \mu \mathrm{m}$ fractions). Higher values of ${ }^{13} \mathrm{C}$-POC (vs. co-located ${ }^{13} \mathrm{C}$ values for dissolved inorganic carbon - DIC) were taken as indicative of faster growth rates and higher values of ${ }^{15} \mathrm{~N}-\mathrm{PN}$ (vs. co-located ${ }^{15} \mathrm{~N}-\mathrm{NO}_{3}$ source values) as indicative of greater nitrate use (rather than ammonium use, i.e. higher $f$ ratios).

Community responses varied in relation to both regional circulation and the advance of the bloom. Iron-fertilised waters over the plateau developed dominance by very large diatoms $(50-210 \mu \mathrm{m})$ with high BSi / POC ratios, high growth rates, and significant ammonium recycling (lower $f$ ratios) as biomass built up. In contrast, downstream polar frontal waters with a similar or higher iron supply were dominated by smaller diatoms $(20-50 \mu \mathrm{m})$ and exhibited greater am-
\end{abstract}

monium recycling. Stations in a deep-water bathymetrically trapped recirculation south of the polar front with lower iron levels showed the large-cell dominance observed on the plateau but much less biomass. Comparison of these communities to surface water nitrate (and silicate) depletions as a proxy for export shows that the low-biomass recirculation feature had exported similar amounts of nitrogen to the highbiomass blooms over the plateau and north of the polar front. This suggests that early spring trophodynamic and export responses differed between regions with persistent low levels vs. intermittent high levels of iron fertilisation.

\section{Introduction}

Natural iron fertilisation from islands, shelves, and plateaus in the Southern Ocean produces local and downstream elevations of phytoplankton biomass that are $\sim 10$-fold higher than in surrounding high-nutrient low-chlorophyll (HNLC) waters; see, e.g., de Baar et al. (1995). In some of these systems, carbon export has been observed to be elevated $\sim 2$ 
3 fold, e.g over the Kerguelen Plateau (Blain et al., 2008; Savoye et al., 2008) and to the north of Crozet Island (Pollard et al., 2007). But these studies produced order-of-magnitude variations in estimates of the amount of carbon export per unit of iron supply, as have deliberate iron fertilisation studies (Boyd et al., 2007). These variations appear to reflect both observational limitations and system complexity, including the possibility of variations in initial communities prior to fertilisation (as a result of north-south oceanographic variations or the extent of connection to coastal habitats).

General principles for expected phytoplankton responses to iron fertilisation have been elucidated, though they remain to be fully tested. These include increased growth rates for all size classes and elevated new production, i.e. increased nitrate use (e.g. Armstrong, 1999; Maldonado et al., 2001). A prevailing view of the overall community response is that it depends on the interaction of these changes with the response of zooplankton grazers, which are thought to be better able to keep up with small-cell growth and thus to favour the accumulation of larger phytoplankton (Assmy et al., 2013; Morel et al., 1991). This, in turn, may favour export via either direct sinking or aggregation (Smetacek, 1985, 1998). Variations in diatom life cycles and strategies add seasonal complexity to this picture (Queguiner, 2013), and the translation of increases in new production into enhancements in export can be relatively weak, for example, as a result of strong $\mathrm{N}$ recycling (Mosseri et al., 2008).

The KEOPS2 (Kerguelen Ocean and Plateau compared Study 2) expedition sought to examine these and other aspects of community responses to natural iron fertilisation over and downstream of the Kerguelen Plateau, in austral spring, October-November 2011, as detailed in multiple papers in this volume. In this paper, we examine a suite of chemical and isotopic indicators of phytoplankton community structure and function (chemometrics) and relate them to nitrate (and silicate) depletion in surface waters as a proxy for carbon export. The following paragraphs provide an overview of the approach and the structure of the paper.

First, we describe the complex regional circulation, and use it to cluster the stations into five groups (coastal, plateau, waters well downstream near the polar front, and waters in a recirculation close to the plateau; the last group is further subdivided into a broad early survey and a later focused, quasi-Lagrangian time series). For these groups we briefly summarise the relative levels of iron fertilisation from dissolved and particulate standing stocks (Quéroué et al., 2014; van der Merwe et al., 2014) and Fe supply estimates (Bowie et al., 2014; d'Ovidio et al., 2014). We also assess the elapsed time since iron fertilisation and its persistence from seasonal perspectives on vertical mixing (Bowie et al., 2014) and Lagrangian perspectives on water mass trajectories around the Kerguelen Plateau (d'Ovidio et al., 2014). We also consider two other overarching perspectives on ecosystem responses: the time elapsed since the beginning of phytoplankton accumulation (from an animation of satellite ocean colour im- ages; see the Supplement) and the level of biomass enrichment at the time of sampling. Our subsequent chemometric analysis is undertaken at the level of these five groups against this framework of relative intensities and timings of Fe fertilisation and biomass accumulation.

Next, we describe our chemometric approach. In brief, we relied on total particulate organic carbon (POC) as an indication of eutrophy, size distribution as a indicator of community structure, biogenic silica / particulate organic carbon (BSi / POC) ratios as a measure of diatom dominance, ${ }^{13} \mathrm{C}$ as a qualitative metric for growth rates, and ${ }^{15} \mathrm{~N}$ as a metric for ammonium recycling. To determine nitrate (and silicic acid) depletion by the biological pump, we explored both temperature and salinity-based approaches to estimate initial winter surface water concentrations and also evaluated the fraction of the observed depletion that still remained in the water column for potential future export using particulate nitrogen and biogenic silica stocks from CTD (conductivity-temperaturedepth) casts (Blain et al., 2014; Lasbleiz et al., 2014).

These chemometric approaches are not as direct as other methods (such as microscopy for community structure, incubation experiments for growth rates and $f$ ratios, and sediment trap collections for export) but offer some advantages in terms of quantitative connections to dissolved nutrient budgets and the ability to examine more sites. To address these shortcomings, we compared our ${ }^{13} \mathrm{C}$ growth rate and ${ }^{15} \mathrm{~N} f$ ratio estimates to shipboard incubation results from ${ }^{13} \mathrm{C}$ and ${ }^{15} \mathrm{~N}$ tracer uptake experiments (Cavagna et al., 2014) and discuss our more extensive results with respect to information on community composition from pigment and microscopic analyses (Lasbleiz et al., 2014) and carbon export from ${ }^{234} \mathrm{Th}$ depletions (Planchon et al., 2014) and sediment trap collections (Laurenceau et al., 2014). In summary, this provides an overview of the relative importance of $\mathrm{Fe}$ inputs and temporal evolution in the control of community structure and carbon export in springtime for the phytoplankton bloom that forms over and downstream of the Kerguelen Plateau.

\section{Methods}

\subsection{Site description}

The KEOPS2 campaign was carried out in OctoberNovember 2011 over and downstream of the Kerguelen Plateau in the Southern Ocean, under conditions of complex circulation and rapidly changing phytoplankton biomass, as summarised in Figs. 1 and 2 and further showcased in the full annual satellite chlorophyll animation (Supplement).

The Kerguelen Plateau is a northwest-southeast-oriented seafloor feature, which rises to $\sim 500 \mathrm{~m}$ below the surface over much of its extent. It also hosts several volcanic islands, in particular the large Kerguelen Island archipelago in the north and the smaller Heard Island at the southern edge of the central Kerguelen Plateau. The plateau blocks 


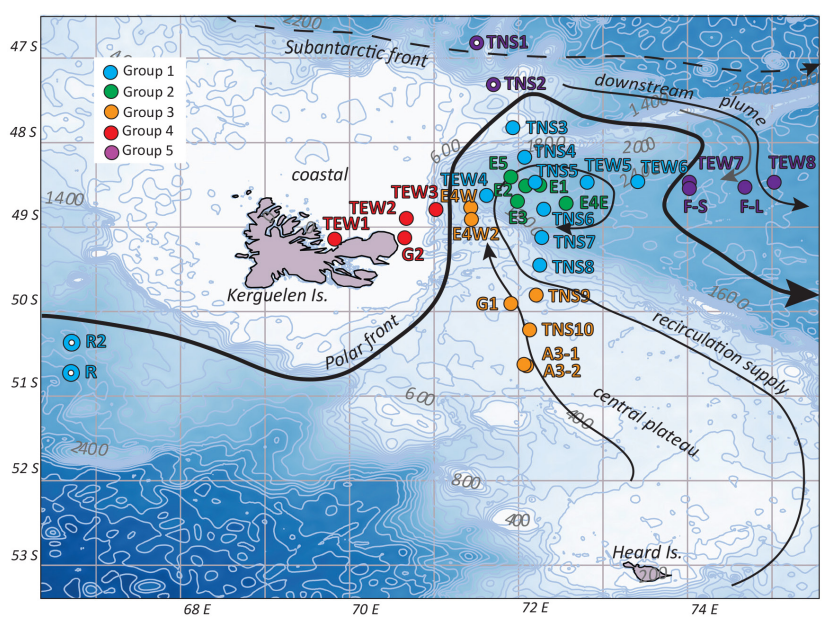

Figure 1. Map of KEOPS2 station locations. The Kerguelen and Heard islands mark the northern and southern end of the central plateau (bathymetry in metres). The polar-front jet that passes through the mid-depth channel south of Kerguelen Island is shown as a bold line. Full ocean depth flows of the Antarctic Circumpolar Current pass to the north of Kerguelen Island in association with the Subantarctic Front and to the south of Heard Island in the Fawn Trough. This latter flow follows the eastern slope of the plateau northwards to bring cold waters into a bathymetrically trapped quasi-stationary recirculation feature (d'Ovidio et al., 2014; Park et al., 2014a). Waters over the central plateau are also carried into this region. During the initial survey, the transect TNS (transect north-south) was sampled first (south to north) and then transect TEW (transect east-west) was sampled west to east. The E stations were designed to provide a Lagrangian temporal sequence in the recirculation region (including some to the east and west of its centre), with interspersed visits to the HNLC reference station (R2); the region of high biomass near and north of the polar front $(\mathrm{F}-$ $\mathrm{L}$ and F-S), and the central plateau bloom station (A3) previously studied in autumn 2005 by the KEOPS project. The E stations were designed to provide a Lagrangian temporal sequence in the recirculation region (including some to the east and west of its centre), with interspersed visits to the HNLC reference station (R2), the region of high biomass near and north of the polar front (F-L and F-S), and the central plateau bloom station (A3) previously studied in autumn 2005 by the KEOPS project. Two additional stations (G1, G2) were sampled for high-volume geochemical tracer studies and provided additional plateau and coastal samples, respectively. The stations are colour-coded according to the five groups as shown on the map (QGIS) and detailed in Table 1.

the eastward flowing Antarctic Circumpolar Current (ACC). Much of the ACC flow goes to the south of the plateau and through the Fawn Trough (to the south of Heard Island), with a smaller portion associated with the Subantarctic Front flowing around the northern edge of Kerguelen Island. A narrow jet of ACC water also flows across the plateau in the narrow, mid-depth $(\sim 1000 \mathrm{~m})$ channel just to the south of Kerguelen Island (Fig. 1). This feature corresponds with the northernmost presence of a subsurface temperature minimum formed by winter cooling (near $200 \mathrm{~m}$ depth) and thus defines the

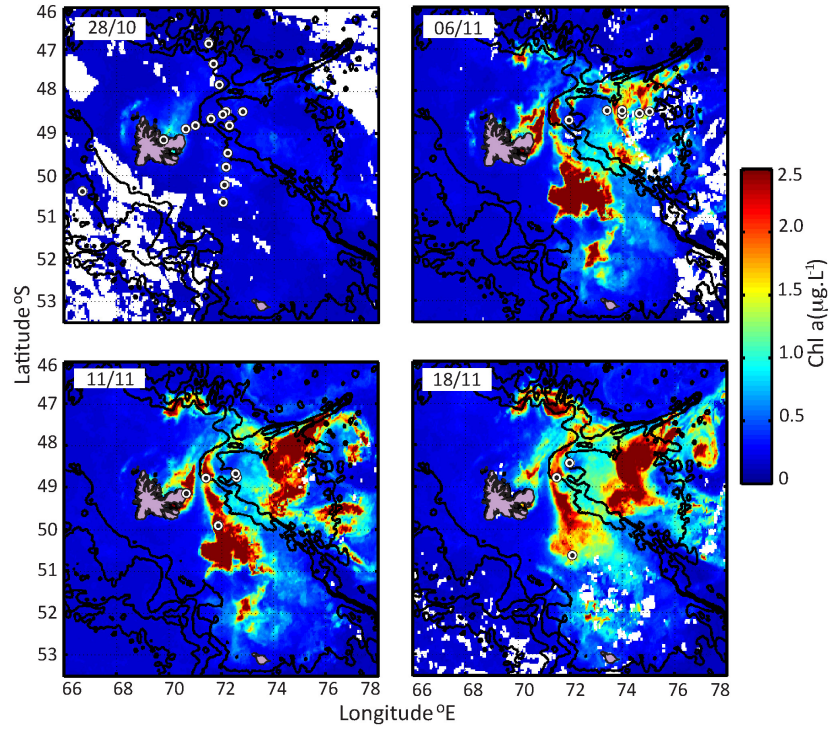

Figure 2. Temporal development of the Kerguelen bloom. Successive images of surface chlorophyll distributions (ocean colour images from NASA MODIS-Aqua imaging spectroradiometer; presented as daily unified data product SSALTO/DUACS $1 \mathrm{~km}$ ) show the bloom development. Image date 28 October: most stations of the initial survey downstream of Kerguelen Island (TNS 1-10, TEW 16), the HNLC reference station (R2, upstream), and the KEOSP1 plateau reference station (A3-1 at the southern end of the TNS transect) were sampled before any significant biomass accumulation had occurred. Image date 6 November: the developing downstream polar-front bloom (TEW 7, TEW 8, F-L, F-S) was sampled early in its development and the recirculation visited a second time (E2). Image date 11 November: the now well-developed central plateau bloom was sampled (G1; E4-W) as well as blooming coastal waters (G2); two more visits to the still low-biomass recirculation were also completed (E3 and E4-E). Image date 18 November: the plateau bloom was resampled as it began to fade (A3-2 and E4W2), along with the final recirculation station (E5). Bathymetry is shown by contours at 1000,2000 , and $3000 \mathrm{~m}$ depths. A full annual animation of the phytoplankton bloom evolution is available in the Supplement.

northernmost branch of the polar front (Park et al., 2014a; Park et al., 2008). This jet was a particularly important feature of the area sampled during KEOPS2 because it separated the central plateau and downstream offshore stations to the south of the polar front (PF) from those to the north of the PF, where the coastal stations were also located. As discussed in Sect. 2.2, the modes of supply of Fe to the waters north and south of this jet may also differ, with some downstream polar-front stations potentially influenced by $\mathrm{Fe}$ inputs from coastal waters associated with Kerguelen Island or its shallow northern shelf (d'Ovidio et al., 2014).

From a dynamical perspective, the full ocean depth branch of the polar front lies to the south of Heard Island, where the ACC flow transits the Fawn Trough (Sokolov and Rintoul, 2009). As this flow passes to the east of the plateau it follows 
the bathymetric contours to the north where it enters a bathymetrically trapped recirculation region to the south of the polar front, before eventually exiting downstream (d'Ovidio et al., 2014; Park et al., 2014a). This recirculation feature and the flow along the PF jet are fixed in space by the bathymetry close to the plateau, but at their eastern edge over the abyssal plain (where the strong ACC flows passing south and north of the plateau rejoin), meandering is strong and varies with time. For example, the animation of ocean colour (Supplement) suggests the PF moved southward in this region over the course of the KEOPS2 observations.

As shown in Fig. 1, the initial sampling was carried out along a deep-water transect (stations TNS 1-10) running northwards from the central plateau (TNS-10) across the recirculation feature and polar front and into subantarctic waters (TNS-1). This was followed by a west to east transect (stations TEW 1-8) running offshore from the Kerguelen Island coast, across the middle of the recirculation, and reaching the southward meandering polar front in the far east of the study region. This initial survey was followed by multiple "time series" visits to the recirculation feature, designated as stations E1-E5, with two stations at the E4 time step to the western side, E4-W, and eastern side, E4-E, of this recirculation. In addition, several other features at the margins of the survey region were also sampled, with rather complicated nomenclature based on locations, links to other programs, durations, and purposes:

- reference HNLC waters to the west of the plateau (stations $\mathrm{R}$ and $\mathrm{R} 2$ );

- a central plateau station that had served as the bloom reference site in the previous KEOPS campaign in late summer/autumn 2005 (station A3, sampled twice as A3-1 and A3-2);

- high-biomass waters in the extreme northeast of the study region, near the downstream location of the polar front (stations F-L and F-S; L for long, S for short);

- two stations selected for comparison of geochemical tracer concentrations in waters over the plateau (G1) with Kerguelen coastal waters (G2).

All of these stations (except TNS-4 and TNS-7) on the initial survey transect were sampled for our size-fractionated chemometric analyses (with some stations also sampled both at night and day).

The five colour-coded groups mapped in Fig. 1 cluster around the KEOPS2 stations based largely on the interactions of the circulation with the bathymetry (with some additional regard for temporal evolution and the timing and extent of iron supply and biomass accumulation, as discussed below). The properties of these groups are summarised in Table 1 . In brief, groups 1 and 2 include stations from the recirculation feature. Group 1 consists of stations in this region occupied during the initial transects when biomass was low and also includes the upstream HNLC reference site R2 (which was also sampled early in the voyage). Group 2 includes the stations subsequently occupied as a pseudo-Lagrangian time series within the recirculation. Group 3 contains the central plateau stations, including those in waters that flow northward to leave the plateau along the south side of the polarfront jet. Group 4 contains the coastal stations, including TEW-3 at the plateau edge (which displayed a mix of coastal, plateau, and recirculation properties). Group 5 has the downstream stations near and north of the polar front. Two stations in this group, at the northern subantarctic end of the initial survey, TNS-1 and TNS-2, were included to keep the number of groups low, but they stand out as quite distinct in having lower biomass with greater proportions of non-diatom taxa (Lasbleiz et al., 2014). They are marked with the group colouring and by an additional white dot. Additional discussion of stations near the boundaries of these groups is provided below, and other clusterings are possible, especially for stations at the boundaries between the groups (for further discussion, see Lasbleiz et al., 2014). The majority of the analysis presented in this paper is based on comparisons across these groups rather than individual stations although variations within the groups do occur and sometimes provide additional insights; for this reason the figures display the individual stations in each group in chronological order (see, e.g., Fig. 3).

\subsection{Intensity and timing of Fe fertilisation}

Iron sampling and analysis was carried out at a muchreduced subset of the stations discussed here, albeit with greater vertical resolution (Bowie et al., 2014; Quéroué et al., 2014; van der Merwe et al., 2014). Thus, comparisons with our results are only possible at the level of our station groups and only in a relative sense. The lowest Fe levels were observed at the HNLC reference station upstream to the west of the Kerguelen Plateau (slightly less than $0.1 \mathrm{nM}$ at station $\mathrm{R} 2$ ). The recirculation region (Groups 1 and 2) had low to moderate dissolved $\mathrm{Fe}(0.06-0.38 \mathrm{nM}$ at stations E2, E3, and E5). Slightly higher minimum concentrations were observed over the plateau $(0.18-0.21 \mathrm{nM}$ at the Group 3 stations A31 and G1). Moderate enrichments were also observed in the Group 5 downstream waters near the polar front $(\sim 0.26 \mathrm{nM}$ at station F-L). The highest dissolved Fe levels were in the Group 4 Kerguelen Island coastal waters (surface concentrations of $2.17 \mathrm{nM}$ for TEW 1 and $1.26 \mathrm{nM}$ for TEW 2).

Particulate Fe levels were not measured in coastal waters but generally exceeded dissolved Fe levels in the Group 3 stations over the plateau (by factors of 13-20), offshore in the Group 1 and 2 stations in the recirculation feature, and the single Group 5 station in the downstream plume (by factors of 2-34). The bioavailability of this particulate $\mathrm{Fe}$ is unknown, but assuming a conservative fraction of $1 \%$ (for discussion, see van der Merwe et al. (2014)) leads to a $20 \%$ 
Table 1. Station groups

\begin{tabular}{|c|c|c|c|c|}
\hline Groups & $\begin{array}{l}\text { Time in } \\
\text { voyage }\end{array}$ & $\begin{array}{l}\text { Time since } \\
\text { bloom start }\end{array}$ & $\begin{array}{l}\text { Biomass at } \\
\text { sampling }\end{array}$ & $\begin{array}{l}\text { Iron } \\
\text { supply }\end{array}$ \\
\hline 1 Recirculation survey ${ }^{\mathrm{a}}$ & early & $\sim 0-1$ week & low & low to mod. \\
\hline 2 Recirc time series & early to late & $\sim 1-3$ weeks & low, stable & moderate \\
\hline 3 Plateau & early, late & $\sim 2-4$ weeks & mod. to high & mod. to high \\
\hline 4 Coastal & early & $\sim 4-6$ weeks & mod., stable & very high \\
\hline 5 Downstream polar front $\mathrm{t}^{\mathrm{b}}$ & middle, late & $\sim 2-4$ weeks & high & mod. to high \\
\hline
\end{tabular}

${ }^{a}$ Also includes HNLC reference stations. ${ }^{b}$ Also includes subantarctic stations.

Fig. 1 shows map of station locations. Fig. 2 shows biomass distributions at the time of sampling Satellite chlorophyll animation (Supplement) shows the full seasonal bloom cycle. Timing of Fe supply is discussed in the text.

increase over the plateau of available iron and a $4-34 \%$ increase offshore.

Estimating Fe supply is more difficult. It appears possible that downstream waters north of the polar front (Group 5 stations F-S, F-L, TEW-7, and TEW-8 but not the subantarctically influenced stations TNS-1 and TNS-2 ) receive more iron than the plateau (Group 3), especially in summer when stratification reduces vertical supply over the plateau, but advection continues to sweep iron-rich coastal waters from the northern Kerguelen Shelf along the northern side of the polar-front jet (Bowie et al., 2014; d'Ovidio et al., 2014; Park et al., 2014a).

The nature of $\mathrm{Fe}$ fertilisation also varies among the regions, in terms of both its timing relative to our sampling and its persistence. Recent and brief iron fertilisation appears likely to characterise the polar front (Group 3 region). Water parcel trajectories calculated from drifter trajectories and altimetry-based geostrophic currents (d'Ovidio et al., 2014) suggest times of less than 0.5 to 1 month for the downstream polar-front stations (Group 5 stations F-S, F-L, TEW7, TEW-8), with a rapid dispersal and thus low persistence. In comparison, it appears to take longer for northern Kerguelen Shelf waters to reach the recirculation region (Group 1 and 2 stations), where the water is then retained for a relatively long time (30 to 60 days) but is also diluted by approximately equal volumes of waters derived from the south (d'Ovidio et al., 2014; Park et al., 2014a). These supply paths are also indicated by $\mathrm{Ra}$ isotope distributions (Sanial et al., 2014). Thus fertilisation of the recirculation feature appears to be less recent and intense than that of the polar frontal region, but probably more persistent. For the Kerguelen coastal stations (Group 4), where water columns were well mixed to the bottom, fertilisation is both recent and persistent. Fertilisation over the plateau is also relatively recent in a seasonal context, $\sim 2$ months from maximum winter mixing in August-September to sampling in October-November. Its persistence may be similar or somewhat larger than that of the recirculation region, given estimates of water parcel residence times over the plateau of the order of 2-3 months (Park et al., 2008).

In summary, this evaluation of iron inputs yields rank orders as follows:
- intensity of $\mathrm{Fe}$ fertilisation (lowest to highest): recirculation feature < plateau $<\approx$ polar-front plume $<<$ coastal stations;

- elapsed time since Fe fertilisation and its persistence (most recent to oldest): polar-front plume $<$ recirculation feature $<\approx$ plateau $<$ coastal stations.

For easy reference these properties are summarised for the station groups in Table 1.

\subsection{Intensity and timing of phytoplankton biomass accumulation}

The KEOPS2 sampling was carried out in spring, spanning the period when phytoplankton biomass was rapidly increasing both over and downstream of the plateau, forming rather complex patterns in satellite chlorophyll images (Fig. 2). Thus the time of sampling relative to the development of surface biomass enrichment varied strongly among the stations. The sequence of ocean colour images in Fig. 2. (see also the Supplement) suggests that this chlorophyll increase occurred first in coastal Kerguelen Island waters (starting in mid-September very close to the island and extending northwards by mid-October, but reaching only moderate $\mathrm{Chl} a$ levels near $1 \mu \mathrm{g} \mathrm{L}^{-1}$ ), followed by the downstream plume north of the polar front (near Group 5 stations F-S, F-L, TEW-7, and TEW-8), where chlorophyll biomass jumped very rapidly from below 0.5 to above $2 \mu \mathrm{g} \mathrm{L}^{-1}$ early in the first week of November.

At this time (as shown in the animation in the Supplement), the central plateau and the recirculation feature still had only minor biomass development, with concentrations near $0.5 \mu \mathrm{g} \mathrm{L}-1$. However, within a few days, by 9 November, all strongly Fe-enriched regions (coastal, central plateau, and the downstream waters near the polar front) had Chl $a$ levels above $2.5 \mu \mathrm{g} \mathrm{L}{ }^{-1}$. Yet the recirculation region still had low levels of $\sim 0.5 \mu \mathrm{g} \mathrm{L}^{-1}$ for another week and only reached levels of $1-1.5 \mu \mathrm{g} \mathrm{L}^{-1}$ by the end of November. Only in early December, after the end of field sampling, did the recirculation feature reach levels of $2.5-3 \mu \mathrm{g} \mathrm{L}^{-1}$. Interestingly, the downstream waters near the polar front maintained high levels throughout most of this period, but the central plateau bloom faded (as sampled by station A3-2) before being replaced by a second bloom somewhat further east, though still over the plateau. The animation of these satellite chlorophyll images provides further detail of the structure and sequence of biomass accumulation, both during and after the voyage (Supplement).

In summary, satellite biomass accumulation yields rank orders as follows:

- magnitude of biomass accumulation (lowest to highest, at end of voyage): recirculation feature < coastal stations $<$ plateau $<\approx$ polar-front plume; 

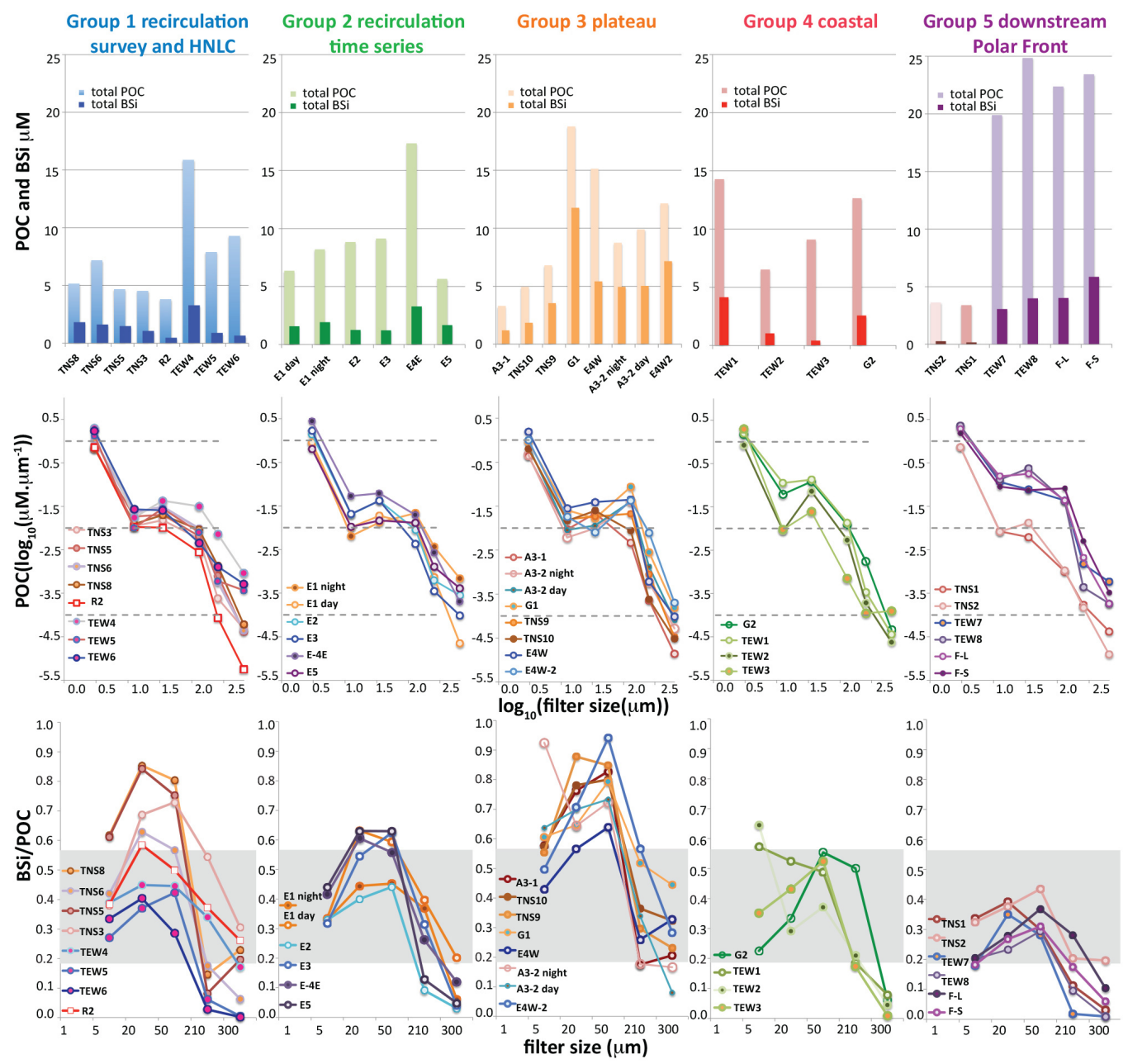

Figure 3. Surface water total and size-fractionated POC and BSi concentrations. Top row: total POC and BSi concentrations for the identified station groups (see Table 1); individual stations in each group are in chronological order from left to right. Middle row: POC size distribution spectra, i.e. concentrations normalised by dividing by the width of the size fraction (i.e. division by 4 for the $1-5 \mu \mathrm{m}$ fraction); dotted lines provide visual guides and reveal little variation among groups for the smallest particles and largest variations in the intermediate size fractions. Bottom row: BSi / POC ratios; grey band indicates approximate range of values for extant diatoms, with higher values possibly indicative of higher iron stress.

- elapsed time since initiation of biomass accumulation (most recent to oldest): recirculation feature < polarfront plume $<\approx$ plateau $<<$ coastal stations.

For easy reference these properties are summarised for the station groups in Table 1.

\subsection{Samples}

This study is based primarily on chemical and isotopic compositions of dissolved nutrients and size-fractionated particles sampled from surface waters using the ship's clean seawater supply. Full details of the sample collection and analytical methods are provided in Appendix A. In brief, particles were analysed for six size fractions collected by largevolume sequential filtration through a prescreen $(1000 \mu \mathrm{m})$ and six filters $(300,210,50,20,5$, and $1 \mu \mathrm{m}$ pore sizes). These samples were analysed for POC, PN (particulate nitrogen), BSi, ${ }^{13} \mathrm{C}-\mathrm{POC}$, and ${ }^{15} \mathrm{~N}-\mathrm{PN}$ (although BSi could not be analysed on the $1 \mu \mathrm{m}$ fraction, as it was collected with a quartz filter). Seawater samples collected from the same supply, and also from Niskin bottles on the CTD system, were analysed for nitrate and dissolved inorganic carbon concentrations and isotopic compositions (DIC, ${ }^{13} \mathrm{C}-\mathrm{DIC}, \mathrm{NO}_{3}^{-}$, ${ }^{15} \mathrm{~N}_{-} \mathrm{NO}_{3}^{-}$, and ${ }^{18} \mathrm{O}-\mathrm{NO}_{3}^{-}$). In addition, samples of approximately $1 \mathrm{~L}$ were filtered for bulk POC and PN concentrations and these are reported along with the total POC determined from the sum of the size fractions. Surface water nitrate concentrations were continuously mapped using an ultraviolet nitrate sensor. 
Speaking broadly for all stations, the largest size fractions $(300-1000 \mu \mathrm{m})$ for the suspended particles were dominated by zooplankton, primarily copepods. Intact faecal pellets and phytoplankton aggregates did not contribute significantly to these fractions (presumably they were disaggregated by the pumping system because both particle types were observed in sediment traps equipped with polyacrylamide gels (Laurenceau et al., 2014); although the presence of intact needles of Thalassiothrix antarctica and chains of Fragilariopsis kerguelensis diatoms suggests individual cells were largely undamaged). The smaller size fractions were dominated by diatom frustules, with small centric diatoms abundant on the $5 \mu \mathrm{m}$ filter, a mix of centric and pennate diatoms on the 20 and $50 \mu \mathrm{m}$ filters, and large diatoms and chains of pennate diatoms and small copepods on the $210 \mu \mathrm{m}$ filter. The particles on the $1 \mu \mathrm{m}$ quartz filter were too small to examine in any detail using stereomicroscopy. The light beige colour of these filters, in comparison to the greener shades of the intermediate sizes suggests important contributions from detritus and/or bacteria (absorption of dissolved organic matter onto the $1 \mu \mathrm{m}$ quartz filters may also have occurred but was not assessed). These microscopic assessments of the materials present on the filters are rather limited and may well have missed significant contributions from autotrophs and heterotrophs without frustules or carapaces, but other studies during KEOPS2 of bacterial abundances (Christaki et al., 2014), phytoplankton (Georges et al., 2014; Lasbleiz et al., 2014), diatom species (L. Armand, personal communication, 2014), and zooplankton (Carlotti et al., 2014) are consistent with our chemometric interpretation that detritus, bacteria, and phytoplankton contributed to the $1 \mu \mathrm{m}$ fraction; phytoplankton and especially diatoms dominated the 5, 20, and $50 \mu \mathrm{m}$ fractions; a mix of large diatoms and copepods were present in the $210 \mu \mathrm{m}$ fraction and copepods, isopods, and occasionally krill were the primary contributions to the $300 \mu \mathrm{m}$ fraction.

\subsection{Chemometric methods for community structure and function}

Evaluation of community structure and function is ideally done via detailed taxonomy and physiology, but the plethora of organisms makes this very difficult. Chemical methods offer an easier path with the added advantages of quantitative connections to dissolved chemical concentrations and budgets. Size fractionation adds value to this approach, firstly because it provides some separation of phytoplankton (which dominated the $1,5,20$, and $50 \mu \mathrm{m}$ fractions) from heterotrophs ( 210 and $300 \mu \mathrm{m}$ fractions) and, secondly, because differing sizes of phytoplankton often occupy different biogeochemical niches (e.g. greater reliance on ammonium by small phytoplankton; less contribution to direct export owing to smaller sinking rates) and experience differing ecological couplings (e.g. tighter coupling to grazing control in smaller sizes because smaller zooplankton have shorter life cycles).
Thus our primary chemometric tool is to simply examine variations in the distribution of POC across the size fractions as an indicator of community structure. (To remove the influence of our particular choice of filter sizes, we express the POC concentration variations as spectra, i.e. we divide the concentrations by the width of each filtration interval, yielding units of $\mu \mathrm{M} \mathrm{m}^{-1}$ ). Secondly, we use high BSi / POC ratios as an indication of community dominance by diatoms. This is simplistic given the presence of silicoflagellates at some stations (Lasbleiz et al., 2014) and the occurrence of a wide range of $\mathrm{BSi} / \mathrm{POC}$ ratios in diatoms (Ragueneau et al., 2006). We use low POC / PN ratios as an indication of contributions from heterotrophic biomass (below the values of $\sim 6-7$ that characterise most phytoplankton (Anderson and Sarmiento, 1994; Redfield et al., 1963)).

\subsubsection{Isotopic chemometric principles $-{ }^{13} \mathrm{C}$}

The isotopic chemometric tools are not as common and require greater explanation. Variations in ${ }^{13} \mathrm{C}-\mathrm{POC}$ and ${ }^{15} \mathrm{~N}$ $\mathrm{PN}$ values derive from both primary photosynthetic production and the overlay of secondary heterotrophic imprints, especially in the smallest size fraction $(1-5 \mu \mathrm{m})$ in which bacterial processing was important, and the two largest size fractions (210-300 and 300-1000 $\mu \mathrm{m})$ which contained significant contributions from zooplankton. For the middle size fractions $(5-20,20-50$, and 50-210 $\mu \mathrm{m})$, biomass was dominated by phytoplankton and thus these fractions can be used to examine the impacts of iron fertilisation and other controls on primary production. This is our focus for the use of these tools. In particular we interpret ${ }^{13} \mathrm{C}$ enrichment as potentially indicative of higher growth rates and ${ }^{15} \mathrm{~N}$ enrichment as indicative of higher $f$ ratios (i.e. greater use of nitrate in comparison to reduced forms of nitrogen). In the following paragraphs we introduce quantitative expressions for these relationships but also acknowledge that they rest on many assumptions and are thus indicative rather than definitive. After discussing these autotrophic expressions, we also briefly describe the scale of heterotrophic effects.

Controls on the ${ }^{13} \mathrm{C}$ composition of phytoplankton are complex and have been explored in hundreds of papers since an early survey of the variability in marine carbon isotopic compositions (Craig, 1953), with occasional significant advances and reviews, e.g. Farquhar et al. (1982), Goericke et al. (1994), Laws et al. (1995, 2002), Rau et al. (1996), Schulz et al. (2007), Tortell et al. (2008). In brief, there are two main causes for ${ }^{13} \mathrm{C}$ variations in any given phytoplankton cell. Firstly, the cell ${ }^{13} \mathrm{C}$ content depends on the chemical form of DIC that is assimilated because the less abundant aqueous molecular $\mathrm{CO}_{2}$ form contains much less ${ }^{13} \mathrm{C}$ than the bicarbonate anion form which makes up more than $90 \%$ of the total DIC. At the temperatures pertaining during the KEOPS study, this equilibrium fractionation lowers the ${ }^{13} \mathrm{C}$ content 
of aqueous molecular $\mathrm{CO}_{2}$ by $\sim 11 \%$ (Rau et al., 1997):

${ }^{13} \mathrm{C}-\mathrm{CO}_{2}={ }^{13} \mathrm{C}-\mathrm{DIC}+23.644-9701.5 / T_{\text {kelvin }}$.

Secondly, the cell ${ }^{13} \mathrm{C}$-POC content depends on the extent to which the enzymatic kinetic discrimination against ${ }^{13} \mathrm{C}$ during photosynthetic carbon fixation (of 20-30\%o, varying with the specific metabolic pathways) is expressed. It is only fully expressed when inorganic carbon flow into and out of the cell (supply) is faster than fixation (demand).

Both these effects often lead to higher ${ }^{13} \mathrm{C}$ contents in faster-growing cells because faster growth favours the use of the more abundant bicarbonate form of DIC and also leads to less expression of the kinetic fractionation.

Thus the association of higher ${ }^{13} \mathrm{C}$ contents with fastergrowing cells is very strongly justified for any particular phytoplankton species, from both metabolic understanding and the plethora of batch and chemostat experimental studies. Despite this understanding, inferring growth rates for communities of phytoplankton from field measurements of ${ }^{13} \mathrm{C}$ $\mathrm{POC}$ is fraught with difficulties. The magnitudes of these two main isotopic effects vary strongly among different phytoplankton (and with their conditions of growth including temperature, nutrient and trace metal availability, light levels, specific enzymatic pathways, etc. (Burkhardt et al., 1999b, c; Fontugne et al., 1991; Schulz et al., 2007)), and there is no universal quantitative relationship between growth rate and phytoplankton ${ }^{13} \mathrm{C}$ content. In particular, cell size is a key variable in the control of ${ }^{13} \mathrm{C}$ contents (Popp et al., 1999; Rau et al., 1996, 1997, 1990). This effect is so important that the global range of surface water bulk ${ }^{13} \mathrm{C}$-POC values can be observed across different size fractions within a single Southern Ocean sample (Trull and Armand, 2001). Good correlations between growth rates and ${ }^{13} \mathrm{C}$ contents when cell size is expressed in terms of the surface / volume ratio suggest this results from the balance of supply versus demand (Popp et al., 1998b) of either aqueous $\mathrm{CO}_{2}$ or bicarbonate forms or both (Burkhardt et al., 1999a; Keller and Morel, 1999; Schulz et al., 2007) and with further modulation by other environmental controls such as the availability of light and other nutrients (Burkhardt et al., 1999c; Gervais and Riebesell, 2001; Schulz et al., 2004).

This complexity means that our observed ${ }^{13} \mathrm{C}-\mathrm{POC}$ variations, even within a given size fraction, could arise by multiple mechanisms. Higher ${ }^{13} \mathrm{C}$ contents could reflect faster growth rates (via either greater use of bicarbonate or an increase of fixation of all DIC chemical forms relative to supply) or might instead reflect changes in species with inherently different uptake and assimilation metabolisms or changes in metabolism driven by other controls such as light or iron availability. Our chemometric methods cannot distinguish among these possible causes, and thus our expression of the ${ }^{13} \mathrm{C}-\mathrm{POC}$ variations in terms of growth rate variations can only be viewed as an indicative exercise. To pursue this, we chose a model fitted to chemostat data (Popp et al., 1998b):

${ }^{13} \mathrm{C}-\mathrm{POC}=\left({ }^{13} \mathrm{C}_{\text {source }}-\varepsilon_{\mathrm{f}}\right)+k$ demand-rate/supply-rate,

in which the first term expresses the lowest possible ${ }^{13} \mathrm{C}$ contents of the cell as the growth rate approaches 0 and the second term describes the linear (constant $k$ ) dependence of isotopic composition on the relative rates of $\mathrm{CO}_{2}$ supply into the cell and its cellular fixation. Popp et al. (1998b) assumed the chemical form was aqueous molecular $\mathrm{CO}_{2}$, but further evaluation showed that the data could also be fit by a model allowing either $\mathrm{CO}_{2}$ or bicarbonate uptake or both (Keller and Morel, 1999). Both models assume that the supply rate depends linearly on its external concentration modulated by the surface area of the cell, and thus while the fitting constants we use here are from Popp et al. (1998b), the scaling to the surface / volume ratio $(S / V)$ of the cell is independent of the chemical form of uptake:

${ }^{13} \mathrm{C}-\mathrm{POC}=\left({ }^{13} \mathrm{C}-\mathrm{CO}_{2}-25\right)+182 \mu /\left(\left[\mathrm{CO}_{2}\right] S / V\right)$.

Rewriting this equation for growth rate, $\mu$, and our measured ${ }^{13} \mathrm{C}$-DIC and ${ }^{13} \mathrm{C}$-POC values yields an indicative path to possible growth rates for our size fractions:

$\mu=S / V\left[\mathrm{CO}_{2}\right]\left[{ }^{13} \mathrm{C}-\mathrm{POC}-\left({ }^{13} \mathrm{C}-\mathrm{CO}_{2}-25\right)\right] / 182$,

with ${ }^{13} \mathrm{C}-\mathrm{CO}_{2}$ calculated using Eq. (1), $\left[\mathrm{CO}_{2}\right]$ obtained from underway $p \mathrm{CO}_{2}$ observations (Lo Monaco et al., 2014) and Henry's Law (Weiss, 1974). In this expression, growth rate $\mu$ is in $\mathrm{d}^{-1}, S / V$ in $\mu \mathrm{m}^{-1}$, and $\left[\mathrm{CO}_{2}\right]$ in $\mu \mathrm{Mol} \mathrm{kg}{ }^{-1}$.

This expression provides growth rates that we compare to other estimates. Of course, comparison of these rates is very sensitive to $S / V$ estimates, as well as to all the other possible sources of variations in ${ }^{13} \mathrm{C}$ contents summarised above. For example, a $30 \%$ increase in the mean size of cells, such as could occur within a given size fraction, would yield a $69 \%$ increase in the model growth rate (for spherical cells). For this reason, our growth rate estimates must be viewed with great caution, not only in terms of their absolute magnitudes but also in terms of their relative magnitudes across the different stations.

In comparison to these fractionation effects accompanying primary production, trophic ${ }^{13} \mathrm{C}$ enrichment is thought to be relatively small within a given class of compounds for carbon ( $\sim 1 \%$ per trophic level; Michener and Schell, 1994). However, accumulation of lipids, which are ${ }^{13} \mathrm{C}$-depleted owing to their multi-step synthesis pathways, causes many zooplankton to have lower ${ }^{13} \mathrm{C}$ contents than their diet (Michener and Schell, 1994; Syvaranta and Rautio, 2010). This is a probable contributor to the ${ }^{13} \mathrm{C}$-POC values of the two largest size fractions, as discussed in the results section.

Finally, because our focus is on extracting information about growth conditions for the communities at the time of sampling, we remove the influence of source inorganic carbon isotopic composition spatial variations on the ${ }^{13} \mathrm{C}-\mathrm{POC}$ variations by examining their offset relative to the source: ${ }^{13} \mathrm{C}-\mathrm{POC}_{\mathrm{rs}}={ }^{13} \mathrm{C}-\mathrm{POC}-{ }^{13} \mathrm{C}$-DIC. 


\subsubsection{Isotopic chemometric principles $-{ }^{15} \mathrm{~N}$}

Phytoplankton ${ }^{15} \mathrm{~N}-\mathrm{PN}$ variations result primarily from the relative use of reduced nitrogen (mainly ammonium), which has low ${ }^{15} \mathrm{~N}$ contents, vs. the more abundant nitrate pool, which has higher ${ }^{15} \mathrm{~N}$ contents, and secondarily from variations in the isotopic fractionation accompanying nitrate assimilation (Goericke et al., 1994; Karsh et al., 2003, 2014; Trull et al., 2008). As with the carbon isotopes, we discuss the ${ }^{15} \mathrm{~N}-\mathrm{PN}$ variations relative to co-located ${ }^{15} \mathrm{~N}-\mathrm{NO}_{3}$ source values $\left({ }^{15} \mathrm{~N}-\mathrm{PN}_{\mathrm{rs}}={ }^{15} \mathrm{~N}-\mathrm{PN}-{ }^{15} \mathrm{~N}-\mathrm{NO}_{3}\right)$, to separate source composition effects (that have accumulated from the history of nitrogen metabolism in a given parcel of water) from the fractionation associated with current PN production. This source composition effect was larger for nitrogen than for carbon because variation in ${ }^{15} \mathrm{~N}-\mathrm{NO}_{3}$ values was larger (6.1 to $8.0 \%$ ) and ${ }^{15} \mathrm{~N}-\mathrm{PN}$ variations were smaller $(6 \%$ ).

By estimating expected values for ${ }^{15} \mathrm{~N}-\mathrm{PN}_{\mathrm{rs}}$ formation from nitrate and from ammonium, estimates of new vs. recycled production (i.e. $f$ ratios) can be obtained for each size fraction by mass balance. The observed range of fractionation factors for nitrate assimilation during KEOPS2, namely $\varepsilon_{\text {na }}$ of -4 to $-4.5 \%$, as estimated from ${ }^{15} \mathrm{~N}-\mathrm{NO}_{3}$ variations in the water column (Dehairs et al., 2014), provides an upper limit for growth on nitrate of ${ }^{15} \mathrm{~N}-\mathrm{PN}_{\mathrm{rs}}(-4 \%$ ). For ammonium, the simplest approximation is to use a value just below the lowest observed ${ }^{15} \mathrm{~N}-\mathrm{PN}_{\mathrm{rs}}$, i.e. to assume that these cells grew on ammonium alone (Trull et al., 2008). Using these end members $\left({ }^{15} \mathrm{~N}-\mathrm{PN}_{\mathrm{Nrs}}=-4 \%\right.$ for growth on nitrate; ${ }^{15} \mathrm{~N}-\mathrm{PN}$ Ars $=-8 \%$ o for growth on ammonium) yields $f$ ratio estimates for each size fraction, from

$f=\left({ }^{15} \mathrm{~N}-\mathrm{PN}_{\mathrm{rs}}-{ }^{15} \mathrm{~N}-\mathrm{PN}_{\mathrm{Ars}}\right) /\left({ }^{15} \mathrm{~N}-\mathrm{PN}_{\mathrm{Nrs}}-{ }^{15} \mathrm{~N}-\mathrm{PN}_{\text {Ars }}\right)$.

In comparison to carbon, trophic enrichment of ${ }^{15} \mathrm{~N}$ is relatively large ( $\sim 3 \%$ vs. $\sim 1 \%$; (Michener and Schell, 1994; Wada and Hattori, 1978)), which provides a cautionary note regarding the interpretation of the $f$ ratio estimates. The largest zooplankton-containing size fractions (210-300, $300-1000 \mu \mathrm{m}$ ) have higher ${ }^{15} \mathrm{~N}-\mathrm{PN}_{\mathrm{rs}}$ values than are achievable by primary production and derive from this process.

\section{Results}

\subsection{Total biomass variations}

POC biomass concentrations in surface waters varied from $\sim 3$ to $25 \mu \mathrm{M}$ (Table 2), reported as the total sum of fractions as filtered from as much as $2600 \mathrm{~L}$ of underway supply water, and are in agreement with our $1 \mathrm{~L}$ single-filter bulk filtrations (Appendix A). Although there were some differences in POC results across the multiple sample methodologies of the entire KEOPS2 program, e.g. from underway supply, Niskin bottles, and in situ pumps (Dehairs et al., 2014; Lasbleiz et al., 2014; Tremblay, 2014), these remain to be fully assessed, and here we focus on our own internally consistent results.
There were significant variations in POC concentrations within the groups as well as among them (Fig. 3). The upstream Fe-poor HNLC reference station R2 and the Group 3 plateau station A3-1, which was sampled early and was the furthest south and coldest, had the lowest values. The recirculation initial-survey stations in Group 1 had somewhat higher values $(5-10 \mu \mathrm{M}$; with a single higher value of $15 \mu \mathrm{M}$ at TEW-4, attributable to a high heterotrophic contribution to its largest size fractions), with little increase over time as represented by the Group 2 recirculation time series (again with a single outlier at E4-E). The Group 5 downstream polarfront bloom stations had the highest biomasses, exceeding all but one of the Group 3 plateau stations as well as all Group 4 coastal stations. Note that the Group 5 stations from warmer waters north of and near the Subantarctic Front (TNS 1 and 2), where the upstream flow may not cross the Kerguelen Shelf, stand out from the other Group 5 stations as having much lower biomass, similar to the upstream HNLC reference station (R2). This distribution of POC among the groups provides important results: (i) waters that have not crossed the plateau have low biomass, presumably reflecting a lack of Fe fertilisation, and (ii) downstream blooms achieve higher concentrations of biomass than coastal blooms. Given that $\mathrm{Fe}$ concentrations were highest in the coastal waters ( $\mathrm{Ta}-$ ble 1; Sect. 2.2), this means that ecosystem dynamics must also contribute importantly to the control of biomass.

Distributions of POC with particle size also varied significantly (Fig. 3). All stations exhibited the highest concentrations in the smallest size fraction $(1-5 \mu \mathrm{m})$ when normalised to the width of this fraction interval (Fig. 3), but these concentrations were relatively constant across the groups. In contrast the concentrations in the three phytoplanktondominated intermediate size fractions $(5,20,50 \mu \mathrm{m}$ filters $)$ varied among the groups and drove the total POC biomass changes described above. There were significant variations within these three size fractions as well. Abundance decreased monotonically with size at the HNLC reference station. The Group 1, and even more so the Group 2, stations exhibited greater increases (as total biomass increased either among stations in Group 1 or with time in the Group 2 time series; note that Table 2 lists all stations in chronological order) in the $20 \mu \mathrm{m}$ fraction than the $5 \mu \mathrm{m}$ fraction but still low values in the $50 \mu \mathrm{m}$ fraction. The Group 3 plateau stations started with this slightly "humped" POC distribution (i.e. POC higher in the $20 \mu \mathrm{m}$ fraction than in both the 5 and $50 \mu \mathrm{m}$ fractions), but, as biomass increased with time, the $50 \mu \mathrm{m}$ fraction came to dominate. Interestingly, this never occurred in the Group 4 coastal or Group 5 polar frontal biomass-rich stations, which remained dominated by the $20 \mu \mathrm{m}$ size fraction.

Heterotrophic biomass (as represented by the two largest size filters, 210 and $300 \mu \mathrm{m}$ ) was generally 1 order of magnitude lower than autotrophic biomass (as represented by the three intermediate fractions) and more than 2 orders of magnitude lower if the smallest fraction is also included as 
an autotroph fraction. Heterotrophic biomass generally increased with total biomass in all the groups, except the Group 4 coastal waters. As mentioned earlier, station TEW-4 in Group 1 had unusually high heterotrophic biomass, which explains its outlier status of exceptionally high total POC for this group.

\subsection{Variations in BSi concentrations and associated contributions to biomass}

BSi estimates were not possible for the smallest size fraction (owing to the use of a quartz $1 \mu \mathrm{m}$ filter). Thus total BSi is underestimated, and comparisons to total POC must be done cautiously. As shown in Fig. 3 (top row), the highest BSi levels were observed in the plateau stations late in the voyage, with these exceeding those of the Group 5 polar frontal bloom stations as well as all the other groups. The lowest levels were in the polar frontal zone and subantarctic stations (Group 5, stations TNS1 and 2). More detailed evaluation is possible on a size-fractionated basis. The initial survey of Group 1 low-biomass waters found a wide range of $\mathrm{BSi}$ / POC ratios that covered most of the variability seen across the entire KEOPS2 study (Fig. 3; bottom row). Among the other groups, the Group 3 plateau stations stand out for having high $\mathrm{BSi} / \mathrm{POC}$ ratios in all the autotrophic fractions $(5,20,50 \mu \mathrm{m}$ filters), in contrast to uniformly low ratios for the Group 5 stations. The presence of non-zero BSi / POC ratios in many of the largest, zooplankton-dominated size fractions ( 210 and $300 \mu \mathrm{m}$ filters) reflects the presence of chainforming diatoms, although their POC biomass was insignificant in comparison to that of the autotrophic intermediate fractions.

Much of the range in $\mathrm{BSi} / \mathrm{POC}$ ratios for the intermediate size fractions overlaps with that expected for diatoms under iron-impoverished $(\mathrm{BSi} / \mathrm{POC} \sim 0.6)$ to ironreplete (BSi / POC 0.15) conditions (Hoffman et al., 2007; Hutchins and Bruland, 1998; Takeda, 1998), but note that this is a simplistic view of diatom BSi / POC variations in response to $\mathrm{Fe}$ inputs which ignores variations across taxa and across life cycle stages (Leynaert et al., 2004; Marchetti and Cassar, 2009; Ragueneau et al., 2006) . There was no clear correspondence across the groups between $\mathrm{BSi}$ / POC values and $\mathrm{Fe}$ fertilisation levels, in that the Group $4 \mathrm{Fe}$-rich coastal waters had intermediate BSi / POC ratios in comparison to the moderately Fe-rich Group 3 plateau and Group 5 downstream polar-front waters. Community variations in the ratio of diatom to non-diatom taxa thus appear to overprint any dependence of diatom BSi / POC ratios on Fe levels.

\section{3 ${ }^{13} \mathrm{C}$ variations}

We first note that the ${ }^{13} \mathrm{C}-\mathrm{POC}_{\mathrm{rs}}$ values of the HNLC reference station (R-2) were the lowest of all stations, and we take them as an indication of expectations for slowly growing offshore polar phytoplankton (Fig. 4). In comparison,
Group 1 and Group 2 stations (which had indistinguishable ${ }^{13} \mathrm{C}-\mathrm{POC}_{\mathrm{rs}}$ values) were elevated by $\sim 2 \%$ (ranging from 1 to $4 \%$ o) in comparison to the R-2 HNLC reference level. These stations also displayed an increase in ${ }^{13} \mathrm{C}-\mathrm{POC}_{\mathrm{rs}}$ values from the smallest $(1-5 \mu \mathrm{m})$ towards larger size fractions $(5-20,20-50 \mu \mathrm{m})$ before decreasing again in the largest autotrophic size fraction $(50-210 \mu \mathrm{m})$ and generally also in the heterotrophically dominated size fractions (210-300 and $300-1000 \mu \mathrm{m})$. This hump-shaped pattern was also present at the Group 3 plateau stations, where ${ }^{13} \mathrm{C}-\mathrm{POC}_{\mathrm{rs}}$ values were elevated further. The Group 4 coastal stations had the highest ${ }^{13} \mathrm{C}-\mathrm{POC}_{\mathrm{rs}}$ values, with values as high as $-20 \%$.

This pattern has been found before in Antarctic polar waters, with the initial increase in ${ }^{13} \mathrm{C}-\mathrm{POC}_{\mathrm{rs}}$ with size attributed to the effect of a decreasing surface / volume ratio on $\mathrm{CO}_{2}$ uptake (Popp et al., 1998a, 1999) and the subsequent decrease in larger fractions attributed to the presence of needle-shaped diatoms with high surface / volume $(S / V)$ ratios similar to small cells (Trull and Armand, 2001). Detailed $S / V$ estimates for our samples are not yet available to assess this explanation or the influence of the presence of chains of Fragilariopsis kerguelensis, Eucampia antarctica, and Chaetoceros (Hyalochaetae) diatoms which contribute strongly to the larger autotrophic size fractions at many stations (Armand et al., personal communication, 2014). The presence of lipid-rich zooplankton in the two largest size fractions is another probable cause of their low ${ }^{13} \mathrm{C}-\mathrm{POC}$ values, based on low ${ }^{13} \mathrm{C}$-POC values for zooplankton collected with nets during KEOPS2 (Carlotti et al., 2014).

To translate our observed ${ }^{13} \mathrm{C}-\mathrm{POC}$ variations (in the autotrophic size classes) to growth rates using the relationships described in the Methods section (Sect. 2.5.1), we must make some assumptions about the size and shapes of the phytoplankton in the different filter fractions. This choice is difficult in the absence of detailed observations, and we took a very simple approach of representing the phytoplankton as rectangular prisms with square cross-sections, with the dimensions given in Table 3 for the 1, 5, 20, and $50 \mu \mathrm{m}$ filter fractions. For the two larger fractions, we assumed diatoms were predominantly present as chains (based on microscopy; Armand et al., personal communication, 2014), and that the surface for $\mathrm{CO}_{2}$ exchange was accordingly reduced (the details accompany Table 3 ). These assumptions are of course tenuous because diatom chains vary in their morphology, and, of course, the relationship between $S / V$ and uptake is itself a large assumption, in that it presupposes that both diffusive and active inorganic carbon uptake correlate with cell surface area (see the Methods section for additional discussion of the uncertainties in estimating growth rates from ${ }^{13} \mathrm{C}$-POC contents). Nevertheless, on this basis, we obtained ${ }^{13} \mathrm{C}$ model growth rate variations for each of the autotrophic size fractions (Table 2) and total community growth rates (Fig. 5) for each station by summing results for the four smallest size fractions $(1,5,20,50 \mu \mathrm{m})$. Similar variations across the stations were obtained by limiting the sum 

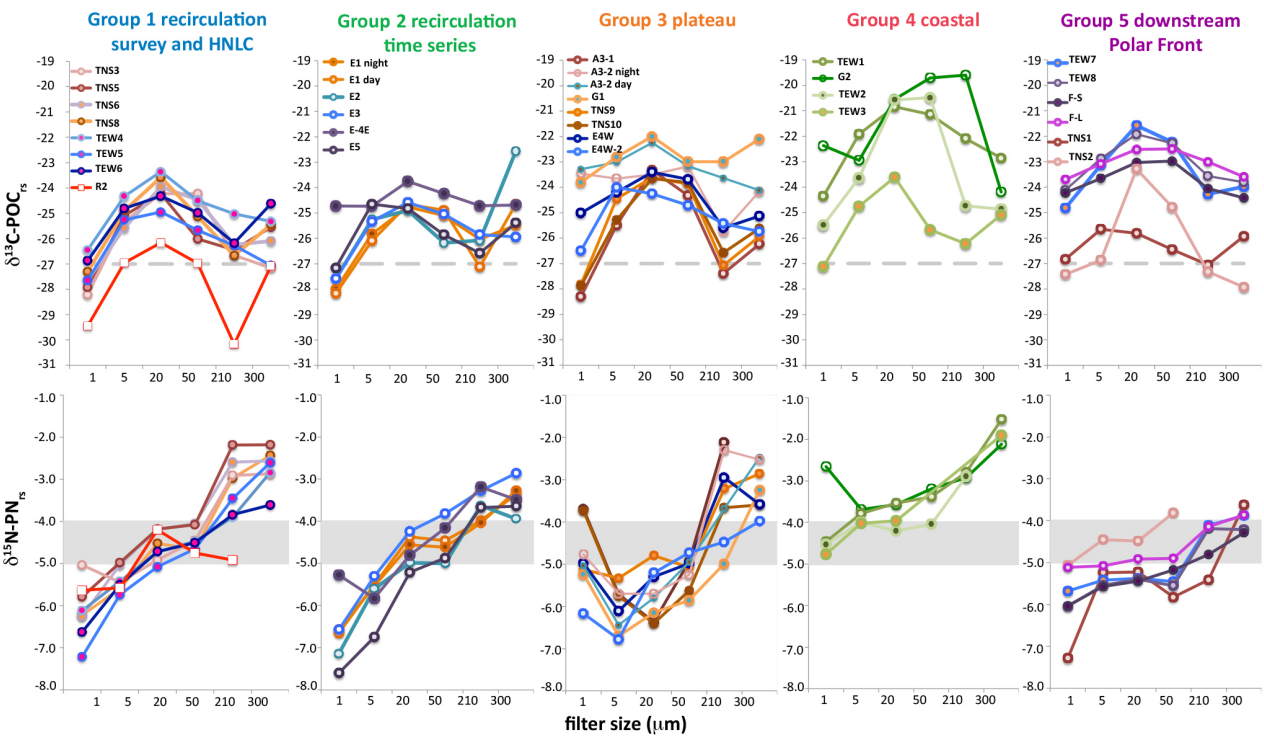

Figure 4. Isotopic variations in the size-fractionated particles. Top row: ${ }^{13} \mathrm{C}-\mathrm{POC}$ values relative to ${ }^{13} \mathrm{C}$-DIC values; dotted line shows the lowest values for the intermediate, autotrophic size fractions samples as observed at upstream Fe-poor reference station (R2). Bottom row: ${ }^{15} \mathrm{~N}-\mathrm{PON}$ values relative to co-located ${ }^{15} \mathrm{~N}-\mathrm{NO}_{3}^{-}$values; grey band indicates values expected for phytoplankton that grow exclusively on nitrate.
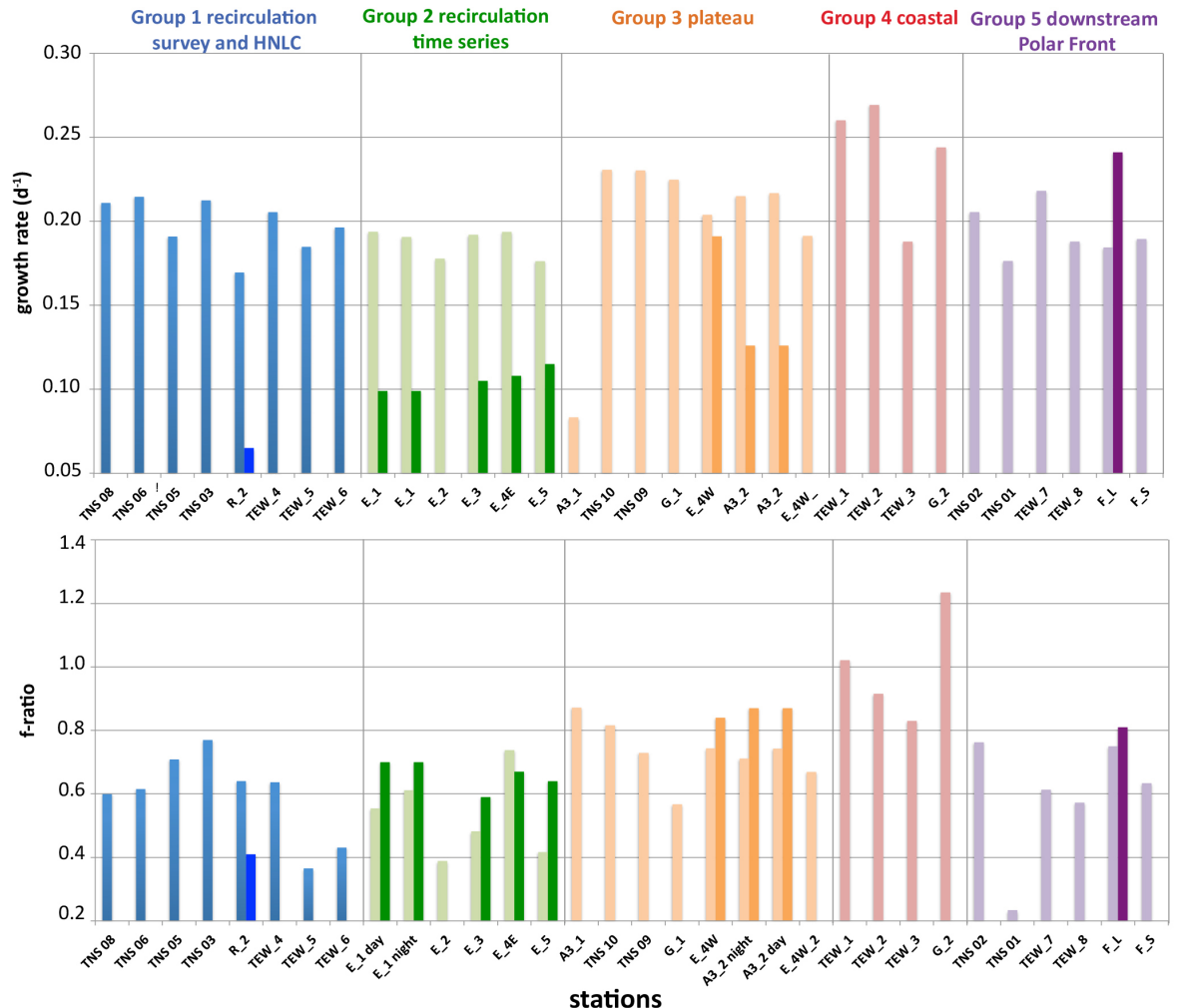

Figure 5. Isotopic chemometric estimates of growth rates and $f$ ratios Top row: growth rates based on the supply vs. demand ${ }^{13} \mathrm{C}$ isotopic fractionation model (summed across the four smallest particle size fractions). Estimates from a limited set of ${ }^{13} \mathrm{C}$ tracer uptake incubations are shown as darker bars (measured at varying light levels and integrated to the mixed layer depth light level; Cavagna et al., 2014). Bottom row: $f$ ratios, i.e. the fraction of total nitrogen nutrition provided by nitrate, based on the ${ }^{15} \mathrm{~N}$ ammonium and ${ }^{15} \mathrm{~N}$ nitrate end-member mixing model (summed across four smallest particle size fractions). Estimates from a limited set of ${ }^{15} \mathrm{~N}$ tracer uptake incubations are shown as darker bars (Cavagna et al., 2014). 
Table 2. Chemometric results for size-fractionated particles.

\begin{tabular}{|c|c|c|c|c|c|c|c|c|c|c|c|c|c|c|}
\hline $\begin{array}{l}\text { Station } \\
\text { Date/location } \\
\text { Group }\end{array}$ & $\begin{array}{r}\text { Volume } \\
\text { L }\end{array}$ & $\begin{array}{r}\text { Fraction } \\
\mu \mathrm{m}\end{array}$ & $\begin{array}{r}\mathrm{POC} \\
\mu \mathrm{M}\end{array}$ & $\begin{array}{l}\mathrm{PN} \\
\mu \mathrm{M}\end{array}$ & $\begin{array}{l}\mathrm{BSi} \\
\mu \mathrm{M}\end{array}$ & $\begin{array}{r}\text { POC / } \\
\text { PN } \\
\text { atom }\end{array}$ & $\begin{array}{l}\mathrm{BSi} / \\
\mathrm{POC} \\
\text { atom }\end{array}$ & $\begin{array}{r}\mathrm{BSi} / \\
\mathrm{PN} \\
\text { atom }\end{array}$ & $\begin{array}{r}\delta^{13} \mathrm{C}-\mathrm{POC} \\
\% o \mathrm{~V}-\mathrm{PDB}\end{array}$ & $\begin{array}{r}\delta^{13} \mathrm{C}-\mathrm{POC}-\delta^{13} \mathrm{C} \text {-DIC } \\
\% \circ \mathrm{V}-\mathrm{PDB} \\
\delta^{\mathbf{1 3}} \mathrm{C} \text {-DIC }\end{array}$ & $\begin{array}{r}\delta^{15} \mathrm{~N}-\mathrm{PN} \\
\% \text { air }\end{array}$ & $\begin{array}{r}\delta^{15} \mathrm{~N}-\mathrm{PN}-\delta^{15} \mathrm{NO} 3 \\
\% \text { air } \\
\delta^{\mathbf{1 5}} \mathrm{NO}_{3}\end{array}$ & $f$ ratio & $\begin{array}{r}\text { Growth rate } \\
\mathrm{d}^{-1} \\
{\left[\mathbf{C O}_{2}\right]_{\mathbf{a q}}}\end{array}$ \\
\hline A3 1 & 1181 & 300 & 0.01 & 0.00 & 0.00 & 11.15 & 0.21 & 2.30 & -25.01 & -26.24 & N/A & N/A & & \\
\hline $20 / 10 / 2011$ & 1181 & 210 & 0.02 & 0.00 & 0.00 & 6.46 & 0.17 & 1.13 & -26.16 & -27.39 & 3.97 & -2.12 & & \\
\hline $50.6300^{\circ} \mathrm{E}$ & 184 & 50 & 0.73 & 0.13 & 0.60 & 5.62 & 0.83 & 4.65 & -23.09 & -24.32 & 1.16 & -4.93 & 0.77 & 0.07 \\
\hline $72.0800^{\circ} \mathrm{S}$ & 184 & 20 & 0.65 & 0.10 & 0.50 & 6.29 & 0.76 & 4.79 & -22.09 & -23.32 & -0.28 & -6.37 & 0.41 & 0.22 \\
\hline \multirow[t]{4}{*}{ Group 3} & 184 & 5 & 0.14 & 0.02 & 0.08 & 7.91 & 0.58 & 4.57 & -24.25 & -25.49 & 0.37 & -5.72 & 0.57 & 0.58 \\
\hline & 184 & 1 & 1.74 & 0.33 & & 5.29 & & & -27.07 & -28.31 & 2.39 & -3.70 & 1.08 & 0.89 \\
\hline & & total & 3.29 & 0.58 & 1.19 & 5.63 & 0.77 & 4.65 & -25.07 & & 1.59 & & 0.87 & 0.08 \\
\hline & & bulk & 3.55 & 0.64 & & 5.52 & & & & 1.23 & & 6.09 & & 24.23 \\
\hline TNS 10 & 1599 & 300 & 0.02 & 0.00 & 0.01 & 6.53 & 0.32 & 2.11 & -24.35 & -25.62 & 2.64 & -3.59 & & \\
\hline $21 / 10 / 2011$ & 1599 & 210 & 0.02 & 0.00 & 0.01 & 6.17 & 0.36 & 2.25 & -25.30 & -26.57 & 2.57 & -3.66 & & \\
\hline $50.2142^{\circ} \mathrm{E}$ & 271 & 50 & 0.77 & 0.14 & 0.62 & 5.70 & 0.80 & 4.56 & -22.55 & -23.81 & 0.60 & -5.63 & 0.59 & 0.21 \\
\hline $72.1320^{\circ} \mathrm{S}$ & 271 & 20 & 0.42 & 0.07 & 0.33 & 5.93 & 0.78 & 4.63 & -22.38 & -23.65 & -0.18 & -6.41 & 0.40 & 0.56 \\
\hline \multirow[t]{4}{*}{ Group 3} & 271 & 5 & 0.12 & 0.02 & 0.07 & 6.94 & 0.57 & 3.99 & -24.02 & -25.28 & 0.48 & -5.75 & 0.56 & 1.04 \\
\hline & 271 & 1 & 1.42 & 0.26 & & 5.53 & & & -26.61 & -27.88 & 2.49 & -3.74 & 1.07 & 2.27 \\
\hline & & total & 2.77 & 0.49 & 1.03 & 5.69 & 0.76 & 4.48 & -24.70 & & 1.51 & & 0.82 & 0.23 \\
\hline & & bulk & 3.86 & 0.74 & & 5.20 & & & & 1.27 & & 6.23 & & 23.63 \\
\hline TNS 09 & 869 & 300 & 0.03 & 0.00 & 0.01 & 6.84 & 0.23 & 1.58 & -24.63 & -25.93 & 3.47 & -2.86 & & \\
\hline $21 / 10 / 2011$ & 869 & 210 & 0.09 & 0.02 & 0.03 & 5.40 & 0.30 & 1.60 & -25.77 & -27.07 & 3.11 & -3.22 & & \\
\hline $49.7991^{\circ} \mathrm{E}$ & 42 & 50 & 11.60 & 1.82 & 9.84 & 6.37 & 0.85 & 5.41 & -22.57 & -23.87 & 1.25 & -5.08 & 0.73 & 0.21 \\
\hline $72.2002^{\circ} \mathrm{S}$ & 42 & 20 & 1.87 & 0.27 & 1.64 & 7.02 & 0.88 & 6.16 & -22.32 & -23.62 & 1.54 & -4.79 & 0.80 & 0.56 \\
\hline \multirow[t]{4}{*}{ Group 3} & 42 & 5 & 0.81 & 0.12 & 0.45 & 7.03 & 0.55 & 3.90 & -23.15 & -24.45 & 1.00 & -5.33 & 0.67 & 1.11 \\
\hline & 42 & 1 & 8.53 & 1.40 & & 6.11 & & & -26.52 & -27.82 & 1.20 & -5.13 & 0.72 & 2.29 \\
\hline & & total & 22.92 & 3.62 & 11.96 & 6.33 & 0.83 & 5.38 & -24.06 & & 1.26 & & 0.73 & 0.23 \\
\hline & & bulk & 6.97 & 1.17 & & 5.98 & & & & 1.30 & & 6.33 & & 23.63 \\
\hline TNS 08 & 997 & 300 & 0.04 & 0.01 & 0.01 & 5.47 & 0.23 & 1.25 & -24.13 & -25.44 & 3.98 & -2.44 & & \\
\hline $21 / 10 / 2011$ & 997 & 210 & 0.12 & 0.02 & 0.02 & 5.03 & 0.15 & 0.73 & -25.35 & -26.66 & 3.45 & -2.97 & & \\
\hline $49.4628^{\circ} \mathrm{E}$ & 216 & 50 & 1.46 & 0.23 & 1.18 & 6.37 & 0.80 & 5.12 & -23.81 & -25.12 & 1.75 & -4.67 & 0.83 & 0.19 \\
\hline $72.2401^{\circ} \mathrm{S}$ & 216 & 20 & 0.60 & 0.09 & 0.51 & 6.93 & 0.85 & 5.91 & -22.27 & -23.58 & 1.90 & -4.52 & 0.87 & 0.56 \\
\hline \multirow[t]{4}{*}{ Group 1} & 216 & 5 & 0.18 & 0.03 & 0.11 & 6.82 & 0.62 & 4.21 & -23.59 & -24.90 & 0.82 & -5.60 & 0.60 & 1.07 \\
\hline & 216 & 1 & 2.77 & 0.49 & & 5.60 & & & -26.00 & -27.31 & 0.20 & -6.22 & 0.44 & 2.42 \\
\hline & & total & 5.18 & 0.87 & 1.83 & 5.96 & 0.76 & 4.88 & -24.83 & & 0.92 & & 0.60 & 0.21 \\
\hline & & bulk & 6.14 & 1.09 & & 5.61 & & & & 1.31 & & 6.42 & & 23.63 \\
\hline TNS 06 & 1025 & 300 & 0.03 & 0.00 & 0.00 & 6.26 & 0.06 & 0.40 & -24.77 & -26.09 & 3.77 & -2.57 & & \\
\hline $22 / 10 / 2011$ & 1025 & 210 & 0.05 & 0.01 & 0.01 & 5.02 & 0.18 & 0.89 & -24.92 & -26.25 & 3.75 & -2.59 & & \\
\hline $48.7989^{\circ} \mathrm{E}$ & 110 & 50 & 1.56 & 0.27 & 0.88 & 5.86 & 0.57 & 3.32 & -23.14 & -24.46 & 2.29 & -4.05 & 0.99 & 0.19 \\
\hline $72.3006^{\circ} \mathrm{S}$ & 110 & 20 & 0.93 & 0.14 & 0.58 & 6.49 & 0.63 & 4.08 & -22.63 & -23.96 & 2.15 & -4.19 & 0.95 & 0.54 \\
\hline \multirow[t]{4}{*}{ Group 1} & 110 & 5 & 0.34 & 0.05 & 0.14 & 6.93 & 0.42 & 2.91 & -24.25 & -25.57 & 1.31 & -5.03 & 0.74 & 0.99 \\
\hline & 110 & 1 & 4.30 & 0.85 & & 5.04 & & & -26.31 & -27.63 & 0.09 & -6.25 & 0.44 & 2.28 \\
\hline & & total & 7.20 & 1.33 & 1.62 & 5.43 & 0.56 & 3.43 & -25.04 & & 0.84 & & 0.62 & 0.21 \\
\hline & & bulk & 4.73 & 0.79 & & 6.02 & & & & 1.33 & & 6.34 & & 23.18 \\
\hline TNS 05 & 1081 & 300 & 0.03 & 0.01 & 0.01 & 5.67 & 0.20 & 1.11 & -24.28 & -25.55 & 4.06 & -2.18 & & \\
\hline $22 / 10 / 2011$ & 1081 & 210 & 0.07 & 0.02 & 0.01 & 4.80 & 0.08 & 0.39 & -25.18 & -26.45 & 4.06 & -2.18 & & \\
\hline $48.4677^{\circ} \mathrm{E}$ & 151 & 50 & 1.04 & 0.19 & 0.78 & 5.50 & 0.75 & 4.14 & -24.73 & -26.01 & 2.16 & -4.08 & 0.98 & 0.17 \\
\hline $72.2018^{\circ} \mathrm{S}$ & 151 & 20 & 0.61 & 0.09 & 0.51 & 6.53 & 0.84 & 5.50 & -22.95 & -24.23 & 2.06 & -4.18 & 0.95 & 0.52 \\
\hline Group 1 & 151 & 5 & 0.28 & 0.04 & 0.17 & 6.72 & 0.61 & 4.11 & -23.81 & -25.08 & 1.26 & -4.98 & 0.76 & 1.03 \\
\hline & 151 & 1 & 2.66 & 0.49 & & 5.48 & & & -26.64 & -27.92 & 0.45 & -5.79 & 0.55 & 2.20 \\
\hline & & total & 4.68 & 0.83 & 1.48 & 5.65 & 0.73 & 4.29 & -25.54 & & 1.15 & & 0.71 & 0.19 \\
\hline & & bulk & 4.20 & 0.75 & & 5.62 & & & & 1.27 & & 6.24 & & 23.18 \\
\hline TNS 03 & 975 & 300 & 0.03 & 0.01 & 0.01 & 6.14 & 0.31 & 1.88 & -25.91 & -27.16 & 3.33 & -2.87 & & \\
\hline $23 / 10 / 2011$ & 975 & 210 & 0.02 & 0.00 & 0.01 & 7.00 & 0.54 & 3.82 & -25.41 & -26.66 & 3.29 & -2.91 & & \\
\hline $47.8336^{\circ} \mathrm{E}$ & 165 & 50 & 0.91 & 0.16 & 0.66 & 5.82 & 0.73 & 4.25 & -22.98 & -24.23 & 1.74 & -4.46 & 0.89 & 0.19 \\
\hline $71.9196^{\circ} \mathrm{S}$ & 165 & 20 & 0.45 & 0.07 & 0.31 & 6.79 & 0.69 & 4.67 & -22.98 & -24.23 & 1.28 & -4.92 & 0.77 & 0.51 \\
\hline Group 1 & 165 & 5 & 0.17 & 0.02 & 0.06 & 8.09 & 0.38 & 3.07 & -24.07 & -25.32 & 0.75 & -5.45 & 0.64 & 0.99 \\
\hline & 165 & 1 & 2.95 & 0.54 & & 5.51 & & & -26.96 & -28.21 & 1.17 & -5.03 & 0.74 & 2.07 \\
\hline & & total & 4.54 & 0.79 & 1.06 & 5.76 & 0.67 & 4.20 & -25.64 & & 1.30 & & 0.77 & 0.21 \\
\hline & & bulk & 4.04 & 0.69 & & 5.83 & & & & 1.25 & & 6.20 & & 22.75 \\
\hline TNS 02 & 784 & 300 & 0.01 & N/A & 0.00 & N/A & 0.20 & N/A & -26.60 & -27.93 & N/A & N/A & & \\
\hline $23 / 10 / 2011$ & 784 & 210 & 0.01 & 0.00 & 0.00 & 10.77 & 0.20 & 2.19 & -25.99 & -27.32 & N/A & N/A & & \\
\hline $47.3318^{\circ} \mathrm{E}$ & 170 & 50 & 0.17 & 0.02 & 0.07 & 8.20 & 0.43 & 3.57 & -23.46 & -24.79 & 2.57 & -3.81 & 1.05 & 0.18 \\
\hline $71.7013^{\circ} \mathrm{S}$ & 170 & 20 & 0.40 & 0.06 & 0.15 & 6.32 & 0.38 & 2.38 & -21.95 & -23.28 & 1.89 & -4.49 & 0.88 & 0.55 \\
\hline Group 5 & 170 & 5 & 0.12 & 0.02 & 0.04 & 6.98 & 0.32 & 2.27 & -25.54 & -26.87 & 1.93 & -4.45 & 0.89 & 0.85 \\
\hline & 170 & 1 & 2.91 & 0.53 & & 5.45 & & & -26.09 & -27.43 & 1.32 & -5.06 & 0.73 & 2.27 \\
\hline & & total & 3.62 & 0.64 & 0.27 & 5.69 & 0.38 & 2.61 & -25.50 & & 1.43 & & 0.76 & 0.21 \\
\hline & & bulk & 2.60 & 0.44 & & 5.92 & & & & 1.33 & & 6.38 & & 22.75 \\
\hline TNS 01 & 1279 & 300 & 0.03 & 0.01 & 0.00 & 5.53 & 0.03 & 0.18 & -25.14 & -25.93 & 3.32 & -3.62 & & \\
\hline $23 / 10 / 2011$ & 1279 & 210 & 0.02 & 0.00 & 0.00 & 7.21 & 0.11 & 0.81 & -26.26 & -27.05 & 1.53 & -5.41 & & \\
\hline $46.8333^{\circ} \mathrm{E}$ & 256 & 50 & 0.16 & 0.02 & 0.05 & 6.77 & 0.30 & 2.03 & -25.66 & -26.45 & 1.12 & -5.82 & 0.54 & 0.16 \\
\hline $71.5011^{\circ} \mathrm{S}$ & 256 & 20 & 0.19 & 0.03 & 0.07 & 6.83 & 0.39 & 2.68 & -25.02 & -25.81 & 1.71 & -5.23 & 0.69 & 0.45 \\
\hline Group 5 & 256 & 5 & 0.13 & 0.02 & 0.04 & 7.22 & 0.34 & 2.43 & -24.86 & -25.65 & 1.70 & -5.24 & 0.69 & 0.96 \\
\hline & 256 & 1 & 2.88 & 0.52 & & 5.52 & & & -26.04 & -26.83 & -0.34 & -7.28 & 0.18 & 2.42 \\
\hline & & total & 3.40 & 0.60 & 0.17 & 5.69 & 0.32 & 2.19 & -25.92 & & -0.09 & & 0.23 & 0.18 \\
\hline & & bulk & 3.70 & 0.59 & & 6.32 & & & & 0.79 & & 6.94 & 23.05 & \\
\hline
\end{tabular}


Table 2. Continued.

\begin{tabular}{|c|c|c|c|c|c|c|c|c|c|c|c|c|c|c|}
\hline $\begin{array}{l}\text { Station } \\
\text { Date/location } \\
\text { Group }\end{array}$ & $\begin{array}{r}\text { Volume } \\
\text { L }\end{array}$ & $\begin{array}{r}\text { Fraction } \\
\mu \mathrm{m}\end{array}$ & $\begin{array}{r}\mathrm{POC} \\
\mu \mathrm{M}\end{array}$ & $\begin{array}{l}\mathrm{PN} \\
\mu \mathrm{M}\end{array}$ & $\begin{array}{l}\mathrm{BSi} \\
\mu \mathrm{M}\end{array}$ & $\begin{array}{r}\mathrm{POC} / \\
\mathrm{PN} \\
\text { atom }\end{array}$ & $\begin{array}{l}\mathrm{BSi} / \\
\mathrm{POC} \\
\text { atom }\end{array}$ & $\begin{array}{r}\mathrm{BSi} / \\
\mathrm{PN} \\
\text { atom }\end{array}$ & $\begin{array}{c}\delta^{13} \mathrm{C}-\mathrm{POC} \\
\% \circ \mathrm{V}-\mathrm{PDB}\end{array}$ & $\begin{array}{r}\delta^{13} \mathrm{C}-\mathrm{POC}-\delta^{13} \mathrm{C}-\mathrm{DIC} \\
\% \text {-V-PDB } \\
\delta^{13} \mathrm{C}-\mathrm{DIC}\end{array}$ & $\begin{array}{r}\delta^{15} \mathrm{~N}-\mathrm{PN} \\
\% \text { air }\end{array}$ & $\begin{array}{r}\delta^{15} \mathrm{~N}-\mathrm{PN}-\delta^{15} \mathrm{NO} 3 \\
\% \text { air } \\
\delta^{\mathbf{1 5}} \mathbf{N O}_{\mathbf{3}}\end{array}$ & $f$ ratio & $\begin{array}{r}\text { Growth rate } \\
\mathrm{d}^{-1} \\
{\left[\mathrm{CO}_{2}\right]_{\mathbf{a q}}}\end{array}$ \\
\hline R 2 & 2685 & 300 & 0.00 & 0.00 & 0.00 & 10.90 & 0.26 & 2.85 & -25.76 & -27.07 & N/A & N/A & & \\
\hline $26 / 10 / 2011$ & 2685 & 210 & 0.01 & 0.00 & 0.00 & 9.92 & 0.37 & 3.70 & -28.86 & -30.18 & 1.56 & -4.92 & & \\
\hline $50.3587^{\circ} \mathrm{E}$ & 167 & 50 & 0.45 & 0.07 & 0.23 & 6.23 & 0.50 & 3.11 & -25.66 & -26.97 & 1.73 & -4.75 & 0.81 & 0.15 \\
\hline $66.7168^{\circ} \mathrm{S}$ & 167 & 20 & 0.31 & 0.04 & 0.18 & 6.94 & 0.58 & 4.06 & -24.84 & -26.16 & 2.28 & -4.20 & 0.95 & 0.44 \\
\hline \multirow[t]{4}{*}{ Group 1} & 167 & 5 & 0.16 & 0.02 & 0.06 & 8.73 & 0.38 & 3.35 & -25.64 & -26.96 & 0.90 & -5.58 & 0.60 & 0.85 \\
\hline & 167 & 1 & 2.89 & 0.51 & N/A & 5.71 & & & -28.14 & -29.45 & 0.84 & -5.64 & 0.59 & 1.80 \\
\hline & & total & 3.82 & 0.64 & 0.47 & 5.94 & 0.51 & 3.46 & -27.48 & & 1.04 & & 0.64 & 0.17 \\
\hline & & bulk & 2.37 & 0.40 & & 5.95 & & & & 1.31 & & 6.48 & & 22.85 \\
\hline E 1 day & 1209 & 300 & 0.02 & 0.00 & 0.00 & 7.07 & 0.20 & 1.43 & -23.28 & -24.65 & 3.04 & -3.36 & & \\
\hline $29 / 10 / 2011$ & 1209 & 210 & 0.07 & 0.01 & 0.03 & 5.51 & 0.40 & 2.18 & -25.75 & -27.12 & 2.42 & -3.98 & & \\
\hline $48.4664^{\circ} \mathrm{E}$ & 181 & 50 & 1.92 & 0.31 & 1.14 & 6.18 & 0.59 & 3.67 & -23.52 & -24.89 & 1.94 & -4.46 & 0.88 & 0.17 \\
\hline $72.1993^{\circ} \mathrm{S}$ & 181 & 20 & 0.57 & 0.09 & 0.36 & 6.64 & 0.63 & 4.20 & -23.29 & -24.66 & 2.03 & -4.37 & 0.91 & 0.47 \\
\hline \multirow[t]{4}{*}{ Group 2} & 181 & 5 & 0.15 & 0.02 & 0.05 & 6.97 & 0.34 & 2.34 & -24.73 & -26.10 & 0.90 & -5.50 & 0.62 & 0.88 \\
\hline & 181 & 1 & 3.64 & 0.62 & & 5.87 & & & -26.81 & -28.18 & -0.25 & -6.65 & 0.34 & 2.00 \\
\hline & & total & 6.36 & 1.05 & 1.58 & 6.05 & 0.58 & 3.65 & -25.43 & & 0.64 & & 0.55 & 0.19 \\
\hline & & bulk & 4.85 & 0.78 & & 6.19 & & & & 1.37 & & 6.40 & & 21.88 \\
\hline E 1 night & 2449 & 300 & 0.48 & 0.11 & 0.03 & 4.45 & 0.06 & 0.28 & -24.26 & -25.48 & 3.24 & -3.28 & & \\
\hline $29 / 10 / 2011$ & 2449 & 210 & 0.33 & 0.06 & 0.12 & 5.26 & 0.37 & 1.94 & -24.82 & -26.03 & 2.48 & -4.04 & & \\
\hline $48.4664^{\circ} \mathrm{E}$ & 310 & 50 & 3.45 & 0.57 & 1.56 & 6.10 & 0.45 & 2.76 & -23.88 & -25.10 & 1.91 & -4.61 & 0.85 & 0.17 \\
\hline $72.1993^{\circ} \mathrm{S}$ & 310 & 20 & 0.40 & 0.06 & 0.18 & 6.64 & 0.44 & 2.95 & -23.55 & -24.76 & 1.96 & -4.56 & 0.86 & 0.47 \\
\hline \multirow[t]{4}{*}{ Group 2} & 310 & 5 & 0.10 & 0.01 & 0.03 & 6.85 & 0.33 & 2.25 & -24.62 & -25.83 & 0.98 & -5.54 & 0.62 & 0.90 \\
\hline & 310 & 1 & 3.45 & 0.58 & & 5.90 & & & -26.79 & -28.00 & -0.04 & -6.56 & 0.36 & 2.04 \\
\hline & & total & 8.21 & 1.40 & 1.92 & 5.88 & 0.40 & 2.37 & -25.16 & & 1.21 & & 0.61 & 0.19 \\
\hline & & bulk & 5.11 & 0.79 & & 6.45 & & & & 1.22 & & 6.52 & & 21.88 \\
\hline TEW 1 & 1516 & 300 & 0.03 & 0.01 & 0.00 & 5.06 & 0.08 & 0.39 & -21.37 & -22.85 & 5.05 & -1.52 & & \\
\hline $31 / 10 / 2011$ & 1516 & 210 & 0.03 & 0.01 & 0.01 & 4.88 & 0.19 & 0.91 & -20.62 & -22.10 & 3.78 & -2.79 & & \\
\hline $49.1502^{\circ} \mathrm{E}$ & 59 & 50 & 2.19 & 0.39 & 1.07 & 5.62 & 0.49 & 2.75 & -19.66 & -21.14 & 3.19 & -3.38 & 1.15 & 0.23 \\
\hline $69.8323^{\circ} \mathrm{S}$ & 59 & 20 & 4.02 & 0.69 & 2.11 & 5.83 & 0.52 & 3.06 & -19.36 & -20.84 & 3.04 & -3.53 & 1.12 & 0.64 \\
\hline \multirow[t]{4}{*}{ Group 4} & 59 & 5 & 1.68 & 0.29 & 0.97 & 5.90 & 0.57 & 3.39 & -20.44 & -21.92 & 2.79 & -3.78 & 1.05 & 1.25 \\
\hline & 59 & 1 & 6.34 & 0.93 & & 6.82 & & & -22.88 & -24.36 & 2.11 & -4.46 & 0.89 & 2.96 \\
\hline & & total & 14.29 & 2.30 & 4.15 & 6.20 & 0.52 & 3.02 & -21.10 & & 2.66 & & 1.02 & 0.26 \\
\hline & & bulk & 9.29 & 1.57 & & 5.93 & & & & 1.48 & & 6.57 & & 22.17 \\
\hline TEW 2 & 650 & 300 & 0.02 & 0.00 & 0.00 & 6.18 & 0.04 & 0.28 & -23.47 & -24.86 & N/A & N/A & & \\
\hline $31 / 10 / 2011$ & 650 & 210 & 0.02 & 0.00 & 0.00 & 5.88 & 0.21 & 1.24 & -23.34 & -24.74 & 3.52 & -2.89 & & \\
\hline $48.8994^{\circ} \mathrm{E}$ & 161 & 50 & 0.88 & 0.14 & 0.33 & 6.21 & 0.37 & 2.31 & -19.09 & -20.48 & 2.37 & -4.04 & 0.99 & 0.24 \\
\hline $70.6663^{\circ} \mathrm{S}$ & 161 & 20 & 2.16 & 0.36 & 0.63 & 6.09 & 0.29 & 1.77 & -19.18 & -20.57 & 2.20 & -4.21 & 0.95 & 0.65 \\
\hline \multirow[t]{4}{*}{ Group 4} & 161 & 5 & 0.13 & 0.02 & 0.09 & 7.25 & 0.64 & 4.67 & -22.24 & -23.63 & 2.41 & -4.00 & 1.00 & 1.11 \\
\hline & 161 & 1 & 3.33 & 0.50 & N/A & 6.64 & & & -24.10 & -25.49 & 1.88 & -4.53 & 0.87 & 2.68 \\
\hline & & total & 6.53 & 1.02 & 1.05 & 6.39 & 0.33 & 2.01 & -21.76 & & 2.07 & & 0.92 & 0.27 \\
\hline & & bulk & 8.14 & 1.33 & & 6.11 & & & & 1.39 & & 6.41 & & 22.17 \\
\hline TEW 3 & 981 & 300 & 0.09 & 0.02 & 0.00 & 4.15 & 0.01 & 0.04 & -23.87 & -25.09 & 4.05 & -1.90 & & \\
\hline $31 / 10 / 2011$ & 981 & 210 & 0.01 & 0.00 & 0.00 & 5.58 & 0.17 & 0.97 & -25.01 & -26.23 & N/A & N/A & & \\
\hline $48.7991^{\circ} \mathrm{E}$ & 93 & 50 & 0.11 & 0.02 & 0.06 & 5.82 & 0.52 & 3.05 & -24.46 & -25.67 & N/A & N/A & N/A & 0.16 \\
\hline $71.0176^{\circ} \mathrm{S}$ & 93 & 20 & 0.74 & 0.12 & 0.32 & 6.23 & 0.43 & 2.69 & -22.39 & -23.61 & 1.99 & -3.96 & 1.01 & 0.52 \\
\hline Group 4 & 93 & 5 & 0.14 & 0.02 & 0.05 & 7.86 & 0.35 & 2.76 & -23.54 & -24.75 & 1.93 & -4.02 & 1.00 & 1.01 \\
\hline & 93 & 1 & 8.01 & 1.27 & & 6.30 & & & -25.92 & -27.13 & 1.19 & -4.76 & 0.81 & 2.28 \\
\hline & & total & 9.10 & 1.45 & 0.43 & 6.28 & 0.40 & 2.41 & -25.56 & & 1.29 & & 0.83 & 0.19 \\
\hline & & bulk & 6.26 & 0.89 & & 7.04 & & & & 1.21 & & 5.95 & & 22.17 \\
\hline TEW 4 & 1150 & 300 & 0.64 & 0.13 & 0.11 & 4.87 & 0.17 & 0.84 & -24.66 & -25.32 & 3.65 & -2.84 & & \\
\hline $1 / 11 / 2011$ & 1150 & 210 & 0.65 & 0.13 & 0.22 & 5.05 & 0.34 & 1.72 & -24.36 & -25.02 & 2.59 & -3.90 & & \\
\hline $48.6331^{\circ} \mathrm{E}$ & 88 & 50 & 5.10 & 0.84 & 2.28 & 6.11 & 0.45 & 2.72 & -23.84 & -24.50 & 2.02 & -4.47 & 0.88 & 0.18 \\
\hline $71.6170^{\circ} \mathrm{S}$ & 88 & 20 & 1.27 & 0.21 & 0.57 & 6.18 & 0.45 & 2.77 & -22.69 & -23.35 & 1.76 & -4.73 & 0.82 & 0.53 \\
\hline Group 1 & 88 & 5 & 0.26 & 0.04 & 0.10 & 5.93 & 0.39 & 2.31 & -23.67 & -24.33 & 1.07 & -5.42 & 0.64 & 1.05 \\
\hline & 88 & 1 & 7.95 & 1.45 & & 5.48 & & & -25.79 & -26.45 & 0.37 & -6.12 & 0.47 & 2.45 \\
\hline & & total & 15.89 & 2.80 & 3.28 & 5.68 & 0.41 & 2.44 & -24.77 & & 1.23 & & 0.64 & 0.21 \\
\hline & & bulk & 9.41 & 1.73 & & 5.43 & & & & 0.66 & & 6.49 & & 22.17 \\
\hline E 2 & 1748 & 300 & 0.20 & 0.04 & 0.01 & 4.38 & 0.03 & 0.14 & -21.25 & -22.57 & 2.68 & -3.94 & & \\
\hline $1 / 11 / 2011$ & 1748 & 210 & 0.06 & 0.01 & 0.01 & 4.65 & 0.09 & 0.42 & -24.76 & -26.08 & 2.99 & -3.63 & & \\
\hline $48.5234^{\circ} \mathrm{E}$ & 123 & 50 & 1.44 & 0.25 & 0.63 & 5.71 & 0.44 & 2.52 & -24.85 & -26.17 & 1.62 & -5.00 & 0.75 & 0.16 \\
\hline $72.0771^{\circ} \mathrm{S}$ & 123 & 20 & 1.26 & 0.20 & 0.50 & 6.22 & 0.40 & 2.49 & -23.58 & -24.90 & 1.64 & -4.98 & 0.75 & 0.47 \\
\hline Group 2 & 123 & 5 & 0.30 & 0.05 & 0.10 & 6.38 & 0.33 & 2.10 & -23.94 & -25.26 & 1.02 & -5.60 & 0.60 & 0.97 \\
\hline & 123 & 1 & 5.60 & 1.01 & & 5.55 & & & -26.27 & -27.59 & -0.52 & -7.14 & 0.22 & 2.17 \\
\hline & & total & 8.85 & 1.57 & 1.25 & 5.65 & 0.38 & 2.24 & -25.46 & 21.00 & 0.27 & (1) & 0.39 & 0.18 \\
\hline & & bulk & 6.78 & 1.21 & & 5.62 & & & & 1.32 & & 6.62 & & $\begin{array}{r}0.10 \\
22.17\end{array}$ \\
\hline TEW 5 & 1748 & 300 & 0.26 & 0.06 & 0.00 & 4.39 & 0.01 & 0.02 & -25.67 & -27.05 & 4.18 & -2.60 & & \\
\hline $1 / 11 / 2011$ & 1748 & 210 & 0.05 & 0.01 & 0.00 & 4.57 & 0.06 & 0.28 & -24.90 & -26.27 & 3.33 & -3.45 & & \\
\hline $48.4678^{\circ} \mathrm{E}$ & 123 & 50 & 1.28 & 0.21 & 0.54 & 6.00 & 0.42 & 2.53 & -24.29 & -25.67 & 2.13 & -4.65 & 0.84 & 0.16 \\
\hline $72.7997^{\circ} \mathrm{S}$ & 123 & 20 & 0.85 & 0.13 & 0.31 & 6.58 & 0.37 & 2.44 & -23.57 & -24.95 & 1.70 & $\begin{array}{l}-4.03 \\
-5.08\end{array}$ & $\begin{array}{l}0.84 \\
0.73\end{array}$ & $\begin{array}{l}0.10 \\
0.47\end{array}$ \\
\hline Group 1 & 123 & 5 & 0.15 & 0.02 & 0.04 & 6.26 & 0.27 & 1.70 & -23.88 & -25.26 & 1.04 & -5.74 & 0.56 & 0.97 \\
\hline & 123 & 1 & 5.32 & 0.90 & & 5.89 & & & -26.27 & -27.65 & -0.43 & -7.21 & 0.20 & 2.16 \\
\hline & & total & 7.91 & 1.34 & 0.90 & 5.90 & 0.35 & 2.06 & -25.59 & & 0.44 & & 0.37 & 0.18 \\
\hline & & bulk & 8.25 & 1.49 & & 5.52 & & & & 1.38 & & 6.78 & & 22.17 \\
\hline
\end{tabular}


Table 2. Continued.

\begin{tabular}{|c|c|c|c|c|c|c|c|c|c|c|c|c|c|c|}
\hline $\begin{array}{l}\text { Station } \\
\text { Date/location } \\
\text { Group }\end{array}$ & $\begin{array}{r}\text { Volume } \\
\mathrm{L}\end{array}$ & $\begin{array}{r}\text { Fraction } \\
\mu \mathrm{m}\end{array}$ & $\begin{array}{r}\text { POC } \\
\mu \mathrm{M}\end{array}$ & $\begin{array}{l}\mathrm{PN} \\
\mu \mathrm{M}\end{array}$ & $\begin{array}{l}\mathrm{BSi} \\
\mu \mathrm{M}\end{array}$ & $\begin{array}{r}\mathrm{POC} / \\
\mathrm{PN} \\
\text { atom }\end{array}$ & $\begin{array}{l}\mathrm{BSi} / \\
\mathrm{POC} \\
\text { atom }\end{array}$ & $\begin{array}{r}\mathrm{BSi} / \\
\mathrm{PN} \\
\text { atom }\end{array}$ & $\begin{array}{c}\delta^{13} \mathrm{C}-\mathrm{POC} \\
\% \circ \mathrm{V}-\mathrm{PDB}\end{array}$ & $\begin{array}{r}\delta^{13} \mathrm{C}-\mathrm{POC}-\delta^{13} \mathrm{C}-\mathrm{DIC} \\
\% \text { oV-PDB } \\
\delta^{13} \mathrm{C}-\mathrm{DIC}\end{array}$ & $\begin{array}{r}\delta^{15} \mathrm{~N}-\mathrm{PN} \\
\% \text { air }\end{array}$ & $\begin{array}{r}\delta^{15} \mathrm{~N}-\mathrm{PN}-\delta^{15} \mathrm{NO} 3 \\
\% \text { air } \\
\boldsymbol{\delta}^{\mathbf{1 5}} \mathbf{N O}_{\mathbf{3}}\end{array}$ & $f$ ratio & $\begin{array}{r}\text { Growth rate } \\
\mathrm{d}^{-1} \\
{\left[\mathbf{C O}_{2}\right]_{\mathbf{a q}}}\end{array}$ \\
\hline TEW 6 & 986 & 300 & 0.36 & 0.09 & 0.00 & 4.17 & 0.00 & 0.01 & -23.24 & -24.63 & 3.21 & -3.61 & & \\
\hline $1 / 11 / 2011$ & 986 & 210 & 0.12 & 0.03 & 0.00 & 4.47 & 0.03 & 0.12 & -24.79 & -26.18 & 2.98 & -3.84 & & \\
\hline $48.4662^{\circ} \mathrm{E}$ & 76 & 50 & 0.74 & 0.13 & 0.21 & 5.74 & 0.29 & 1.65 & -23.59 & -24.98 & 2.31 & -4.51 & 0.87 & 0.18 \\
\hline $73.3998^{\circ} \mathrm{S}$ & 76 & 20 & 0.77 & 0.12 & 0.31 & 6.51 & 0.40 & 2.63 & -22.93 & -24.32 & 2.10 & -4.72 & 0.82 & 0.49 \\
\hline \multirow[t]{4}{*}{ Group 1} & 76 & 5 & 0.40 & 0.07 & 0.14 & 5.72 & 0.33 & 1.91 & -23.42 & -24.81 & 1.31 & -5.51 & 0.62 & 1.00 \\
\hline & 76 & 1 & 6.91 & 1.33 & & 5.20 & & & -25.49 & -26.88 & 0.19 & -6.63 & 0.34 & 2.35 \\
\hline & & total & 9.31 & 1.76 & 0.66 & 5.29 & 0.28 & 1.54 & -24.94 & & 0.71 & & 0.43 & 0.20 \\
\hline & & bulk & 6.38 & 1.14 & & 5.62 & & & & 1.39 & & 6.82 & & 22.17 \\
\hline TEW 7 & 957 & 300 & 0.41 & 0.09 & 0.00 & 4.58 & 0.01 & 0.04 & -22.23 & -23.98 & 3.89 & -3.87 & & \\
\hline $2 / 11 / 2011$ & 957 & 210 & 0.13 & 0.03 & 0.00 & 4.97 & 0.02 & 0.09 & -22.53 & -24.28 & 3.65 & -4.11 & & \\
\hline $48.4667^{\circ} \mathrm{E}$ & 35 & 50 & 6.89 & 1.19 & 1.93 & 5.81 & 0.28 & 1.63 & -20.48 & -22.23 & 2.31 & -5.45 & 0.64 & 0.20 \\
\hline $73.9992^{\circ} \mathrm{S}$ & 35 & 20 & 2.32 & 0.37 & 0.81 & 6.27 & 0.35 & 2.20 & -19.82 & -21.57 & 2.38 & -5.38 & 0.66 & 0.55 \\
\hline \multirow{4}{*}{ Group 5} & 35 & 5 & 1.71 & 0.29 & 0.31 & 5.89 & 0.18 & 1.05 & -21.38 & -23.12 & 2.34 & -5.42 & 0.64 & 1.03 \\
\hline & 35 & 1 & 8.43 & 1.58 & & 5.32 & & & -23.08 & -24.83 & 2.08 & -5.68 & 0.58 & 2.56 \\
\hline & & total & 19.90 & 3.55 & 3.06 & 5.61 & 0.27 & 1.56 & -21.63 & & 2.27 & & 0.61 & 0.22 \\
\hline & & bulk & 22.82 & 4.09 & & 5.58 & & & & 1.75 & & 7.76 & & 20.04 \\
\hline TEW 8 & 1509 & 300 & 0.13 & 0.03 & 0.00 & 4.90 & 0.01 & 0.05 & -22.06 & -23.80 & 3.79 & -4.21 & & \\
\hline $2 / 11 / 2011$ & 1509 & 210 & 0.04 & 0.01 & 0.00 & 5.04 & 0.10 & 0.48 & -21.83 & -23.57 & 3.81 & -4.19 & & \\
\hline $48.4676^{\circ} \mathrm{E}$ & 56 & 50 & 6.61 & 1.07 & 1.94 & 6.16 & 0.29 & 1.81 & -20.53 & -22.27 & 2.45 & -5.55 & 0.61 & 0.17 \\
\hline $75.0032^{\circ} \mathrm{S}$ & 56 & 20 & 7.10 & 1.15 & 1.65 & 6.17 & 0.23 & 1.43 & -20.17 & -21.91 & 2.60 & -5.40 & 0.65 & 0.46 \\
\hline \multirow[t]{4}{*}{ Group 5} & 56 & 5 & 1.95 & 0.30 & 0.39 & 6.44 & 0.20 & 1.30 & -21.14 & -22.88 & 2.46 & -5.54 & 0.61 & 0.91 \\
\hline & 56 & 1 & 9.02 & 1.73 & & 5.23 & & & -22.38 & -24.12 & 1.95 & -6.05 & 0.49 & 2.35 \\
\hline & & total & 24.86 & 4.29 & 3.99 & 5.80 & 0.25 & 1.56 & -21.16 & & 2.30 & & 0.57 & 0.19 \\
\hline & & bulk & 23.21 & 3.92 & & 5.92 & & & & 1.74 & & 8.00 & & 17.43 \\
\hline E 3 & 1246 & 300 & 0.07 & 0.01 & 0.00 & 4.84 & 0.04 & 0.20 & -24.53 & -25.94 & 3.47 & -2.86 & & \\
\hline $4 / 11 / 2011$ & 1246 & 210 & 0.03 & 0.01 & 0.01 & 5.25 & 0.31 & 1.65 & -24.44 & -25.85 & 3.05 & -3.28 & & \\
\hline $48.6998^{\circ} \mathrm{E}$ & 85 & 50 & 0.69 & 0.11 & 0.43 & 6.35 & 0.62 & 3.96 & -23.64 & -25.05 & 2.51 & -3.82 & 1.04 & 0.17 \\
\hline $71.9670^{\circ} \mathrm{S}$ & 85 & 20 & 1.25 & 0.19 & 0.68 & 6.68 & 0.55 & 3.64 & -23.18 & -24.59 & 2.09 & -4.24 & 0.94 & 0.48 \\
\hline \multirow[t]{4}{*}{ Group 2} & 85 & 5 & 0.31 & 0.04 & 0.10 & 7.59 & 0.32 & 2.41 & -23.92 & -25.33 & 1.02 & -5.31 & 0.67 & 0.95 \\
\hline & 85 & 1 & 6.79 & 1.24 & & 5.48 & & & -26.18 & -27.59 & -0.24 & -6.57 & 0.36 & 2.14 \\
\hline & & total & 9.13 & 1.60 & 1.22 & 5.72 & 0.52 & 3.43 & -25.49 & & 0.30 & & 0.48 & 0.19 \\
\hline & & bulk & 7.58 & 1.34 & & 5.66 & & & & 1.41 & & 6.33 & & 21.88 \\
\hline FL & 1102 & 300 & 0.13 & 0.02 & 0.01 & 5.46 & 0.06 & 0.32 & -21.96 & -23.60 & 3.38 & -3.87 & & \\
\hline $6 / 11 / 2011$ & 1102 & 210 & 0.19 & 0.04 & 0.03 & 4.98 & 0.17 & 0.87 & -21.36 & -23.00 & 3.11 & -4.14 & & \\
\hline $48.5232^{\circ} \mathrm{E}$ & 60 & 50 & 6.93 & 1.17 & 2.14 & 5.91 & 0.31 & 1.83 & -20.85 & -22.49 & 2.35 & -4.90 & 0.78 & 0.17 \\
\hline $74.6673^{\circ} \mathrm{S}$ & 60 & 20 & 5.32 & 0.92 & 1.42 & 5.80 & 0.27 & 1.55 & -20.88 & -22.52 & 2.33 & -4.92 & 0.77 & 0.44 \\
\hline \multirow[t]{4}{*}{ Group 5} & 60 & 5 & 2.31 & 0.39 & 0.42 & 5.88 & 0.18 & 1.07 & -21.44 & -23.08 & 2.17 & -5.08 & 0.73 & 0.90 \\
\hline & 60 & 1 & 7.51 & 1.41 & & 5.32 & & & -22.07 & -23.71 & 2.14 & -5.11 & 0.72 & 2.43 \\
\hline & & total & 22.38 & 3.95 & 4.03 & 5.66 & 0.27 & 1.58 & -21.34 & & 2.26 & & 0.75 & 0.18 \\
\hline & & bulk & 15.76 & 2.89 & & & & & & 1.64 & & 7.25 & & 17.43 \\
\hline F S & 571 & 300 & 0.23 & 0.05 & 0.02 & 5.03 & 0.10 & 0.52 & -22.71 & -24.42 & 3.50 & -4.29 & & \\
\hline $8 / 11 / 2011$ & 571 & 210 & 0.45 & 0.09 & 0.13 & 5.21 & 0.28 & 1.46 & -22.34 & -24.05 & 2.98 & -4.81 & & \\
\hline $48.5006^{\circ} \mathrm{E}$ & 110 & 50 & 13.05 & 2.20 & 4.80 & 5.93 & 0.37 & 2.18 & -21.26 & -22.97 & 2.61 & -5.18 & 0.71 & 0.17 \\
\hline $73.9998^{\circ} \mathrm{S}$ & 110 & 20 & 2.24 & 0.36 & 0.62 & 6.15 & 0.28 & 1.71 & -21.32 & -23.03 & 2.34 & -5.45 & 0.64 & 0.45 \\
\hline Group 5 & 110 & 5 & 1.34 & 0.23 & 0.27 & 5.91 & 0.20 & 1.21 & -21.94 & -23.66 & 2.22 & -5.57 & 0.61 & 0.91 \\
\hline & 110 & 1 & 6.12 & 1.10 & & 5.57 & & & -22.51 & -24.22 & 1.76 & -6.03 & 0.49 & 2.48 \\
\hline & & total & 23.43 & 4.02 & 5.85 & 5.82 & 0.34 & 2.00 & -21.67 & & 2.35 & & 0.63 & 0.19 \\
\hline & & bulk & 15.76 & 2.89 & & 5.45 & & & & 1.71 & & 7.79 & & 18.55 \\
\hline G 1 & 1457 & 300 & 0.11 & 0.02 & 0.05 & 5.69 & 0.44 & 2.53 & -20.54 & -22.09 & 3.84 & -3.25 & & \\
\hline $8 / 11 / 2011$ & 1457 & 210 & 0.25 & 0.04 & 0.13 & 5.78 & 0.52 & 2.99 & -21.43 & -22.99 & 2.10 & -4.99 & & \\
\hline $49.9004^{\circ} \mathrm{E}$ & 116 & 50 & 13.92 & 2.20 & 11.04 & 6.32 & 0.79 & 5.01 & -21.43 & -22.99 & 1.24 & -5.85 & 0.54 & 0.20 \\
\hline $71.8991^{\circ} \mathrm{S}$ & 116 & 20 & 0.50 & 0.08 & 0.32 & 6.58 & 0.65 & 4.25 & -20.44 & -22.00 & 0.94 & -6.15 & 0.46 & 0.57 \\
\hline Group 3 & 116 & 5 & 0.38 & 0.06 & 0.23 & 6.29 & 0.61 & 3.81 & -21.25 & -22.81 & 0.39 & -6.70 & 0.32 & 1.14 \\
\hline & 116 & 1 & 3.64 & 0.73 & & 5.00 & & & -22.25 & -23.80 & 1.85 & -5.24 & 0.69 & 3.01 \\
\hline & & total & 18.79 & 3.13 & 11.77 & 6.01 & 0.78 & 4.90 & -21.56 & (n) & 1.38 & (n) & 0.57 & 0.22 \\
\hline & & bulk & 19.40 & 3.29 & & 5.90 & & & & 1.55 & & 7.09 & & 21.59 \\
\hline G 2 & 631 & 300 & 0.03 & 0.01 & 0.00 & 5.78 & 0.06 & 0.36 & -22.64 & -24.19 & 4.41 & -2.12 & & \\
\hline $9 / 11 / 2011$ & 631 & 210 & 0.16 & 0.03 & 0.08 & 5.52 & 0.50 & 2.77 & -18.04 & -19.60 & 3.61 & -2.92 & & \\
\hline $49.1331^{\circ} \mathrm{E}$ & 61 & 50 & 1.94 & 0.32 & 1.07 & 6.03 & 0.55 & 3.34 & -18.16 & -19.71 & 3.34 & -3.19 & 1.20 & 0.22 \\
\hline $70.6498^{\circ} \mathrm{S}$ & 61 & 20 & 3.63 & 0.61 & 1.21 & 5.93 & 0.33 & 1.98 & -18.99 & -20.54 & 2.96 & -3.57 & 1.11 & 0.56 \\
\hline Group 4 & 61 & 5 & 0.92 & 0.17 & 0.21 & 5.54 & 0.23 & 1.25 & -21.40 & -22.95 & 2.84 & -3.69 & 1.08 & 1.01 \\
\hline & 61 & 1 & 5.97 & 1.12 & & 5.33 & & & -20.82 & -22.37 & 3.88 & -2.65 & 1.34 & 2.99 \\
\hline & & total & 12.66 & 2.25 & 2.57 & 5.61 & 0.39 & 2.27 & -19.90 & & 3.47 & & 1.23 & 0.24 \\
\hline & & bulk & 13.10 & 2.35 & & 5.56 & & & & 1.55 & & 6.53 & & 19.25 \\
\hline E 4W & 393 & 300 & 0.07 & 0.01 & 0.02 & 6.38 & 0.33 & 2.09 & -23.73 & -25.13 & 2.81 & -3.58 & & \\
\hline $11 / 11 / 2011$ & 393 & 210 & 0.05 & 0.01 & 0.01 & 6.36 & 0.26 & 1.65 & -24.20 & -25.60 & 3.44 & -2.95 & & \\
\hline $48.7667^{\circ} \mathrm{E}$ & 43 & 50 & 7.09 & 1.23 & 4.53 & 5.77 & 0.64 & 3.69 & -22.29 & -23.69 & 1.41 & -4.98 & 0.75 & 0.18 \\
\hline $71.4294^{\circ} \mathrm{S}$ & 43 & 20 & 1.18 & 0.18 & 0.67 & 6.55 & 0.57 & 3.70 & -22.01 & -23.41 & 1.09 & -5.30 & 0.68 & 0.50 \\
\hline Group 3 & 43 & 5 & 0.43 & 0.06 & 0.18 & 7.46 & 0.43 & 3.21 & -22.80 & -24.20 & 0.28 & -6.11 & 0.47 & 0.99 \\
\hline & 43 & 1 & 6.32 & 1.31 & & 4.83 & & & -23.61 & -25.01 & 1.41 & -4.98 & 0.76 & 2.63 \\
\hline & & total & 15.14 & 2.79 & 5.42 & 5.42 & 0.61 & 3.65 & -22.85 & & 1.38 & & 0.74 & 0.20 \\
\hline & & bulk & 12.58 & 2.18 & & 5.78 & & & & 1.40 & & 6.39 & & 20.73 \\
\hline
\end{tabular}


Table 2. Continued.

\begin{tabular}{|c|c|c|c|c|c|c|c|c|c|c|c|c|c|c|}
\hline $\begin{array}{l}\text { Station } \\
\text { Date/location } \\
\text { Group }\end{array}$ & $\begin{array}{r}\text { Volume } \\
\mathrm{L}\end{array}$ & $\begin{array}{r}\text { Fraction } \\
\mu \mathrm{m}\end{array}$ & $\begin{array}{r}\text { POC } \\
\mu \mathrm{M}\end{array}$ & $\begin{array}{l}\mathrm{PN} \\
\mu \mathrm{M}\end{array}$ & $\begin{array}{l}\mathrm{BSi} \\
\mu \mathrm{M}\end{array}$ & $\begin{array}{r}\text { POC / } \\
\text { PN } \\
\text { atom }\end{array}$ & $\begin{array}{l}\mathrm{BSi} / \\
\mathrm{POC} \\
\text { atom }\end{array}$ & $\begin{array}{r}\mathrm{BSi} / \\
\mathrm{PN} \\
\text { atom }\end{array}$ & $\begin{array}{c}\delta^{13} \mathrm{C}-\mathrm{POC} \\
\% o \mathrm{~V}-\mathrm{PDB}\end{array}$ & $\begin{array}{r}\delta^{13} \mathrm{C}-\mathrm{POC}-\delta^{13} \mathrm{C}-\mathrm{DIC} \\
\% \text { - }- \text { PDB } \\
\delta^{13} \mathrm{C} \text {-DIC }\end{array}$ & $\begin{array}{r}\delta^{15} \mathrm{~N}-\mathrm{PN} \\
\% \text { air }\end{array}$ & $\begin{array}{r}\delta^{15} \mathrm{~N}-\mathrm{PN}-\delta^{15} \mathrm{NO} 3 \\
\% \text { air } \\
\boldsymbol{\delta}^{\mathbf{1 5}} \mathbf{N O}_{\mathbf{3}}\end{array}$ & $f$ ratio & $\begin{array}{r}\text { Growth rate } \\
\mathrm{d}^{-1} \\
{\left[\mathrm{CO}_{2}\right]_{\mathbf{a q}}}\end{array}$ \\
\hline E 4E & 974 & 300 & 0.14 & 0.03 & 0.02 & 4.80 & 0.12 & 0.58 & -23.17 & -24.69 & 3.13 & -3.49 & & \\
\hline $13 / 11 / 2011$ & 974 & 210 & 0.24 & 0.05 & 0.06 & 4.71 & 0.26 & 1.23 & -23.19 & -24.71 & 3.44 & -3.18 & & \\
\hline $48.7141^{\circ} \mathrm{E}$ & 32 & 50 & 3.12 & 0.54 & 1.74 & 5.74 & 0.56 & 3.20 & -22.71 & -24.24 & 2.46 & -4.16 & 0.96 & 0.17 \\
\hline $72.5708^{\circ} \mathrm{S}$ & 32 & 20 & 1.86 & 0.29 & 1.12 & 6.39 & 0.61 & 3.87 & -22.23 & -23.75 & 1.82 & -4.80 & 0.80 & 0.48 \\
\hline \multirow[t]{4}{*}{ Group 2} & 32 & 5 & 0.80 & 0.13 & 0.33 & 6.29 & 0.42 & 2.62 & -23.21 & -24.73 & 0.80 & -5.82 & 0.54 & 0.94 \\
\hline & 32 & 1 & 11.19 & 2.01 & & 5.55 & & & -23.20 & -24.72 & 1.35 & -5.27 & 0.68 & 2.48 \\
\hline & & total & 17.35 & 3.06 & 3.28 & 5.68 & 0.53 & 3.15 & -23.01 & & 1.62 & & 0.74 & 0.19 \\
\hline & & bulk & 9.90 & 1.70 & & 5.83 & & & & 1.53 & & 6.62 & & 20.63 \\
\hline A3 2 night & 586 & 300 & 0.04 & 0.01 & 0.01 & 4.83 & 0.17 & 0.80 & -22.85 & -24.16 & 3.79 & -2.53 & & \\
\hline $15 / 11 / 2011$ & 586 & 210 & 0.05 & 0.01 & 0.01 & 4.80 & 0.18 & 0.85 & -24.43 & -25.74 & 4.02 & -2.30 & & \\
\hline $50.6300^{\circ} \mathrm{E}$ & 161 & 50 & 6.42 & 1.06 & 4.65 & 6.08 & 0.72 & 4.40 & -21.86 & -23.17 & 1.06 & -5.26 & 0.69 & 0.19 \\
\hline $72.0802^{\circ} \mathrm{S}$ & 161 & 20 & 0.30 & 0.05 & 0.19 & 6.03 & 0.64 & 3.89 & -22.19 & -23.50 & 0.62 & -5.70 & 0.58 & 0.51 \\
\hline \multirow[t]{4}{*}{ Group 3} & 161 & 5 & 0.09 & 0.02 & 0.08 & 5.81 & 0.92 & 5.37 & -22.34 & -23.66 & 0.62 & -5.70 & 0.57 & 1.06 \\
\hline & 161 & 1 & 1.84 & 0.38 & & 4.87 & & & -22.14 & -23.46 & 1.55 & -4.77 & 0.81 & 3.04 \\
\hline & & total & 8.74 & 1.52 & 4.94 & 5.76 & 0.72 & 4.33 & -21.95 & & 1.20 & & 0.71 & 0.21 \\
\hline & & bulk & 9.60 & 1.78 & & 5.38 & & & & 1.31 & & 6.32 & & 21.04 \\
\hline A3 2 day & 1081 & 300 & 0.06 & 0.01 & 0.00 & 5.26 & 0.08 & 0.43 & -22.78 & -24.12 & 4.02 & -2.47 & & \\
\hline $16 / 11 / 2011$ & 1081 & 210 & 0.12 & 0.02 & 0.04 & 5.48 & 0.34 & 1.86 & -22.30 & -23.64 & 2.81 & -3.68 & & \\
\hline $50.6300^{\circ} \mathrm{E}$ & 209 & 50 & 6.36 & 0.96 & 4.66 & 6.63 & 0.73 & 4.86 & -21.83 & -23.16 & 1.54 & -4.95 & 0.76 & 0.19 \\
\hline $72.0802^{\circ} \mathrm{S}$ & 209 & 20 & 0.34 & 0.05 & 0.24 & 6.47 & 0.70 & 4.53 & -20.91 & -22.24 & 0.69 & -5.80 & 0.55 & 0.55 \\
\hline \multirow[t]{4}{*}{ Group 3} & 209 & 5 & 0.14 & 0.02 & 0.09 & 6.11 & 0.64 & 3.89 & -21.67 & -23.01 & 0.05 & -6.44 & 0.39 & 1.10 \\
\hline & 209 & 1 & 2.90 & 0.58 & & 5.03 & & & -21.95 & -23.28 & 1.45 & -5.04 & 0.74 & 3.07 \\
\hline & & total & 9.91 & 1.64 & 5.03 & 6.03 & 0.72 & 4.72 & -21.84 & & 1.49 & & 0.74 & 0.22 \\
\hline & & bulk & 13.06 & 2.28 & & 5.72 & & & & 1.33 & & 6.49 & & 20.96 \\
\hline E 4W 2 & 1373 & 300 & 0.14 & 0.03 & 0.04 & 4.49 & 0.28 & 1.27 & -24.25 & -25.74 & 2.57 & -3.98 & & \\
\hline $18 / 11 / 2011$ & 1373 & 210 & 0.71 & 0.13 & 0.40 & 5.36 & 0.57 & 3.03 & -23.93 & -25.42 & 2.08 & -4.47 & & \\
\hline $48.7666^{\circ} \mathrm{E}$ & 131 & 50 & 6.82 & 1.13 & 6.42 & 6.02 & 0.94 & 5.66 & -23.22 & -24.71 & 1.82 & -4.73 & 0.82 & 0.17 \\
\hline $71.4798^{\circ} \mathrm{S}$ & 131 & 20 & 0.24 & 0.04 & 0.17 & 6.27 & 0.71 & 4.44 & -22.77 & -24.26 & 1.35 & -5.20 & 0.70 & 0.47 \\
\hline \multirow[t]{4}{*}{ Group 3} & 131 & 5 & 0.27 & 0.05 & 0.13 & 5.62 & 0.50 & 2.79 & -22.50 & -23.99 & -0.23 & -6.78 & 0.31 & 1.02 \\
\hline & 131 & 1 & 3.97 & 0.72 & & 5.54 & & & -25.00 & -26.50 & 0.38 & -6.17 & 0.46 & 2.33 \\
\hline & & total & 12.15 & 2.10 & 7.16 & 5.78 & 0.88 & 5.18 & -23.83 & & 1.30 & & 0.67 & 0.19 \\
\hline & & bulk & 13.36 & 2.51 & & 5.32 & & & & 1.49 & & 6.55 & & 20.96 \\
\hline E 5 & 992 & 300 & 0.29 & 0.07 & 0.01 & 4.02 & 0.05 & 0.20 & -23.96 & -25.40 & 2.97 & -3.64 & & \\
\hline $18 / 11 / 2011$ & 992 & 210 & 0.11 & 0.03 & 0.01 & 4.43 & 0.13 & 0.57 & -25.14 & -26.58 & 2.94 & -3.67 & & \\
\hline $48.4178^{\circ} \mathrm{E}$ & 195 & 50 & 2.08 & 0.36 & 1.31 & 5.84 & 0.63 & 3.67 & -24.42 & -25.86 & 1.74 & -4.87 & 0.78 & 0.16 \\
\hline $71.9973^{\circ} \mathrm{S}$ & 195 & 20 & 0.44 & 0.07 & 0.28 & 6.53 & 0.63 & 4.11 & -23.38 & -24.82 & 1.40 & -5.21 & 0.70 & 0.46 \\
\hline \multirow[t]{4}{*}{ Group 2} & 195 & 5 & 0.16 & 0.03 & 0.07 & 6.14 & 0.44 & 2.70 & -23.21 & -24.65 & -0.14 & -6.75 & 0.31 & 0.98 \\
\hline & 195 & 1 & 2.60 & 0.46 & & 5.61 & & & -25.72 & -27.16 & -0.99 & -7.60 & 0.10 & 2.19 \\
\hline & & total & 5.67 & 1.01 & 1.68 & 5.62 & 0.55 & 3.08 & -24.90 & & 0.53 & & 0.42 & 0.18 \\
\hline & & bulk & 7.59 & 1.31 & & 5.78 & & & & 1.44 & & 6.61 & & 21.43 \\
\hline
\end{tabular}

Note: column headers in bold refer to quantities in bold shown on the bulk sample lines; bulk samples were measured on water and unfractionated particle samples collected separately.

to the 5,20 , and $50 \mu \mathrm{m}$ fraction results (data not shown). The ${ }^{13} \mathrm{C}$ model growth rates decreased with size across the size fractions (from the 1 to the $50 \mu \mathrm{m}$ filter) by factors of 10 to 15 , in excellent agreement with allometric relationships assembled for a much broader range of phytoplankton, although the high growth rates of 2 to $3 \mathrm{~d}^{-1}$ in the smallest fraction are greater than expected for polar waters (Chisholm, 1992; Cózar and Echevarría, 2005). This could reflect significant contributions from detritus from larger autotrophs and bacteria in this fraction or other errors in the model (see the Methods section for discussion of the low fidelity of the ${ }^{13} \mathrm{C}$ model growth rates).

Our community (sum of fractions) ${ }^{13} \mathrm{C}$ model growth rates compare reasonably well with a limited set of incubation results, calculated by integrating results from different light level deck onboard incubations (Cavagna et al., 2014) over the depth of the surface mixed layers as shown in Tables $4 \mathrm{a}$ and b (Park et al., 2014b, a). The overall dynamic range of the incubation and model growth rates was identical $\left(0.18 \mathrm{~d}^{-1}\right)$.
For the model this ranged from $0.08 \mathrm{~d}^{-1}$ at the coldest lowbiomass station sampled early over the plateau (A3-1) to $0.27 \mathrm{~d}^{-1}$ at coastal station TEW-2. The incubations ranged from a low value of $0.065 \mathrm{~d}^{-1}$ at the HNLC reference station (A3-1 was not studied) to a high of $0.24 \mathrm{~d}^{-1}$ at the Group 5 polar-front station F-L (coastal stations were not studied). Overall correlation between the eight pairs of results from the same stations (though not sampled at identical times) was very poor $\left(r^{2}<0.1\right)$, but this was driven by strong disagreement at the single Group 5 downstream polar-front station, where the incubations found their highest depth-integrated growth rate $\left(0.24 \mathrm{~d}^{-1}\right.$ at $\mathrm{F}$-L) but our ${ }^{13} \mathrm{C}$-based estimates were much lower; without this pair, the correlation was reasonably strong $\left(r^{2}=0.67\right)$.

Given the importance of $S / V$ variations to the ${ }^{13} \mathrm{C}$ model growth rate estimates (see the Methods section), variations between groups with similar size distributions and phytoplankton flora (the Group 1 and 2 recirculation and Group 3 plateau stations) are probably more reliably assessed than 
Table 3. Phytoplankton cell dimensions used in ${ }^{13} \mathrm{C}$ supply versus demand model.

\begin{tabular}{|c|c|c|c|c|}
\hline \multirow{2}{*}{$\begin{array}{l}\text { Size fraction } \\
\mu \mathrm{m}\end{array}$} & \multicolumn{3}{|c|}{ Prism dimensions } & \multirow[t]{2}{*}{ Form } \\
\hline & $\mathrm{d} 1$ & $\mathrm{~d} 2$ & $\mathrm{~d} 3$ & \\
\hline $1-5$ & 3 & 3 & 3 & single cells \\
\hline $5-20$ & 7 & 7 & 15 & single cells \\
\hline $20-50$ & 15 & 15 & 30 & chains* \\
\hline $50-210$ & 40 & 40 & 80 & chains* \\
\hline
\end{tabular}

* $\mathrm{CO}_{2}$ exchange is assumed to be negligible on the surface of the cell contact within the chains, taken to be the long faces of the prisms.

variations between groups with more distinct flora (coastal Group 4 stations and downstream polar-front Group 5 stations). The Group 2 recirculation time series showed quite constant and moderate growth rates $\left(0.17-0.19 \mathrm{~d}^{-1}\right)$. Interestingly, values during the earlier Group 1 initial survey were somewhat higher in this region $\left(0.19-0.21 \mathrm{~d}^{-1}\right)$ and reached $0.23 \mathrm{~d}^{-1}$ at the southern end of the north-south transect over the plateau (TNS 9, 10). Group 3 plateau stations (A3-2, G1, E4W, E4W2) that were sampled later also had high ${ }^{13} \mathrm{C}$ model growth rates $\left(0.19-0.24 \mathrm{~d}^{-1}\right)$.

These growth rate variations are in broad agreement with the development of blooms in these regions - in that the lowest biomass accumulation over the study period occurred in the recirculation, with higher values over the plateau. In contrast, the model suggests that the highest growth rates occurred in Group 4 coastal waters, where biomass accumulation was only moderate, and it found only moderate growth rates for the Group 5 polar-front stations, where a strong bloom was already underway at the time of sampling (Fig. 2). Unfortunately, it is not currently possible to determine whether this reflects the simplicity of the model or the complexity of the ecosystem dynamics. This provides a useful cautionary note that the apparent growth rate variations have no real quantitative validity; at best, they provide indicative information on the relative intensities of $\mathrm{CO}_{2}$ assimilation across the groups. Indeed, it is possible that the variations among the groups results from other issues such as species metabolic differences or light and trace element availability (as discussed in detail in the Methods section). Thus it is important to emphasise that the overall view of ecosystem responses developed in the Discussion section below does not depend only on these potential growth rate estimates from the ${ }^{13} \mathrm{C}-\mathrm{POC}$ observations but also draws on biomass accumulation rates from the POC concentrations, their distribution across size fractions, and other indicators as discussed below.

\section{$3.4{ }^{15} \mathrm{~N}$ variations}

Similarly to the carbon isotopes, we discuss the ${ }^{15} \mathrm{~N}$ $\mathrm{PN}$ variations relative to co-located ${ }^{15} \mathrm{~N}_{-} \mathrm{NO}_{3}$ values $\left({ }^{15} \mathrm{~N}\right.$ $\mathrm{PN}_{\mathrm{rs}}={ }^{15} \mathrm{~N}-\mathrm{PN}-{ }^{15} \mathrm{~N}-\mathrm{NO}_{3}$ ), for the reasons outlined in the Methods section (Sect. 2.5.2). As shown in Fig. 4, almost all the phytoplankton-dominated size fractions (5$20,20-50,50-210 \mu \mathrm{m})$ had ${ }^{15} \mathrm{~N}-\mathrm{PN}_{\mathrm{rs}}$ values that fall between the upper bound of production from nitrate $\left({ }^{15} \mathrm{~N}\right.$ $\left.\mathrm{PN}_{\mathrm{rs}}=-4\right)$ and the lower bound of production from ammonium $\left({ }^{15} \mathrm{~N}-\mathrm{PN}_{\mathrm{rs}}=-8\right)$. There was also a tendency across all groups towards lower ${ }^{15} \mathrm{~N}-\mathrm{PN}_{\mathrm{rs}}$ in the smaller phytoplankton fractions; consistent with a greater use of ammonium by smaller phytoplankton (Armstrong, 1999; Karsh et al., 2003). The largest zooplankton-containing size fractions (210-300, $300-1000 \mu \mathrm{m})$ had higher ${ }^{15} \mathrm{~N}-\mathrm{PN}_{\mathrm{rs}}$ values, which presumably result from the relatively large $(\sim 3 \%$ o) trophic enrichment that occurs in many marine organisms (Michener and Schell, 1994; Wada and Hattori, 1978). While these general variations with size held for all groups, there were significant differences. In particular, the Group 3 plateau stations had the lowest ${ }^{15} \mathrm{~N}-\mathrm{PN}_{\mathrm{rs}}$ values for the larger autotrophic size classes (20-50 and 50-210 $\mu \mathrm{m})$.

Using the end-member mixing model (Methods, Sect. 2.5.2), we obtained the estimated community $f$ ratios as shown in Fig. 5. The Group 3 plateau stations tended to have somewhat higher values $(\sim 0.7$ vs. $\sim 0.6)$ than the Group 5 downstream polar-front bloom stations (TEW-7, TEW-8, and F-S); although this was not true for the highest-biomass station (F-L). As with the ${ }^{13} \mathrm{C}$ model growth rates, the Group 1 recirculation stations sampled early on the TNS transit were somewhat surprising in having relatively high values, though these were not observed on the later TEW transit or during the Group 2 time series. Finally, the coastal stations had high apparent $f$ ratios, including values that exceed 1 (pointing to limitations of the model). Importantly, these high values are driven by the relatively low ${ }^{15} \mathrm{~N}^{-\mathrm{NO}_{3}}$ values in these coastal waters rather than by higher ${ }^{15} \mathrm{~N}$ contents in their PN. The low ${ }^{15} \mathrm{~N}_{-} \mathrm{NO}_{3}$ values are a surprise given the relatively low nitrate concentrations in these coastal waters (Fig. 6), suggesting other processes are at work. Our observations are insufficient to explain this. One possibility is the delivery of low ${ }^{15} \mathrm{~N}$ nitrate from sedimentary nitrification, but this still leaves open the question of why recently formed PN does not track the overall nitrate pool isotopic composition. Reliance on the $f$ ratios from these coastal stations is thus not advisable. In contrast, comparison of our offshore $f$ ratios to incubation results (Fig. 5) shows similar values and excellent correlation $\left(r^{2}=0.90 ;\right.$ provided the one very low incubation-based $f$ ratio at the HNLC station R2 is discounted). 


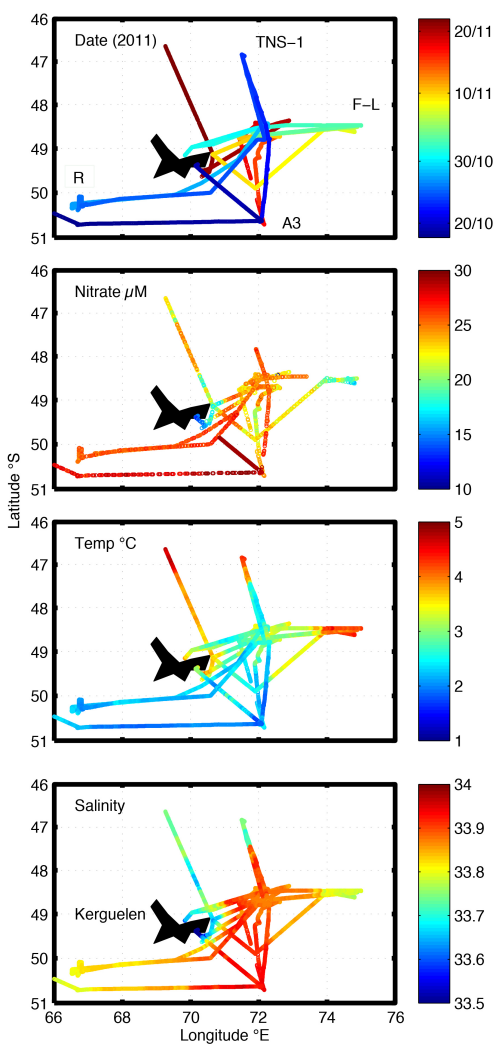

Figure 6. High-resolution distributions of surface water properties from continuous sensor measurements. Top to bottom: ship trajectory as revealed by dates of sampling; nitrate concentrations (from ISUS ultraviolet spectrometry), temperature, and salinity. Stations at the ends of the trajectories are indicated in the top panel to aid in identification when referencing Fig. 1.

\subsection{Nutrient depletion estimates}

Surface water nutrient concentrations provide an initial perspective on the efficiency of the biological pump. The surface nitrate concentrations were lower north than south of the polar front, but of course this may reflect longer-term, basinscale controls on nitrate. The determination of the role of local recent biological activity in nitrate depletion requires a much closer examination. Figure 6 shows high-spatialresolution maps of nitrate, temperature, and salinity obtained with the sensors operated continuously underway. Waters upstream from the plateau and south of the polar front were cold and saline with high nitrate concentrations, with these parameters reaching their highest values over the central plateau early in the voyage (near the Group 3 KEOPS bloom reference station A3-1), with temperature less than $2{ }^{\circ} \mathrm{C}$, salinity greater than 33.9 , and nitrate above $30 \mu \mathrm{M}$. At the other extreme, Group 4 coastal waters had the lowest surface nitrates (below $10 \mu \mathrm{M}$ ), in association with very fresh (salinity <33.6) and relatively warm $\left(>3.5^{\circ} \mathrm{C}\right)$ waters. The Group 5 waters downstream in the bloom that formed north of the polar front well to the east (near $74-75^{\circ} \mathrm{E}$ and the Group 5 stations TEW-7, -8, F-L, and F-S) also had relatively low surface nitrates $(15-20 \mu \mathrm{M})$ and low salinities (33.7-33.8) and were quite warm $\left(>4^{\circ} \mathrm{C}\right)$. In comparison, the Group 2 recirculation feature had intermediate nitrate concentrations between the plateau, coastal, and downstream polar-front plume conditions.

These conditions evolved over the course of the study, with decreases in surface nitrate values being particularly strong (reaching 6-8 $\mu \mathrm{M}$ from winter conditions; Table $4 \mathrm{a}$ ) in regions of rapid biomass accumulation over the central plateau (especially along the plateau edge to the north of the A3 station) and in the bloom north of the polar front (near stations TEW-8, F-L, F-S). Low nitrate concentrations were also found in association with relatively low salinities to the southeast of the recirculation region, where the ship transited without station sampling. This appears to represent the southward supply of waters from north of the polar front in association with its meandering, as also suggested by the satellite chlorophyll image sequences (Fig. 2 and animation in the Supplement) and by water parcel trajectories estimated from drifters and satellite altimetry (d'Ovidio et al., 2014). This process also appears to have driven warming and freshening in the recirculation over time. Thus nitrate budgets require partitioning of temporal changes driven by both hydrology and biology.

To separate local biological nitrate depletion from hydrological controls, we examined nitrate depletions in surface waters relative to estimates of initial winter nitrate concentrations for each station, as estimated from CTD profiles. We considered integrations to two different depths: (a) the frequently used choice (e.g. Arrigo et al., 1999; Sweeney et al., 2000) of the depth of the remnant winter water temperature minimum ( $T_{\min }$-depth), and (b) shallower depths based on a threshold increase in salinity of 0.05 ( $S_{\text {threshold-depth). This }}$ second choice was motivated by the presence of significant salinity gradients above the $T_{\min }$-depth (examples are shown in Fig. 7), particularly in waters near and north of the polar front, suggesting either that the most recent winter mixing was not as deep as in previous years or that horizontal mixing had brought fresher waters over the top of the $T_{\min }$, and thus in either case that nitrate depletion between the $T_{\min }$-depth and $S_{\text {threshold-depth was not attributable to local biological }}$ processes.

The two nitrate depletion metrics give differing views of the contributions to export from the different community groups (as summarised in Fig. 8). Estimates based on the $T_{\min }$ approach were much higher than those from the $S_{\text {threshold }}$ approach because the $T_{\min }$ depth and was generally deeper and had higher nitrate than the $S_{\text {threshold }}$ depth (Table $4 \mathrm{a})$. The $T_{\min }$ approach suggested that the greatest depletion occurred in the downstream plume to the north of the polar front. In contrast, the $S_{\text {threshold }}$ approach identified the highest seasonal nitrate depletion as occurring over the central plateau, with somewhat lower values in the recirculation 
Table 4a. Surface mixed layer $\mathrm{N}$ depletion and export estimates.

\begin{tabular}{|c|c|c|c|c|c|c|c|c|c|c|c|c|c|c|c|}
\hline \multirow[t]{2}{*}{ Station } & \multirow{2}{*}{$\begin{array}{l}\text { CTD } \\
\text { cast }\end{array}$} & \multirow{2}{*}{$\begin{array}{l}\text { Time stamp } \\
\text { mm-dd hh-mm }\end{array}$} & \multicolumn{3}{|c|}{ Depth } & \multicolumn{3}{|c|}{ Nitrate } & \multicolumn{4}{|c|}{ Nitrate depletion } & \multirow{2}{*}{$\begin{array}{r}\text { PN stock } \\
200 \mathrm{~m} \\
\mathrm{mmol} \mathrm{m}^{-2}\end{array}$} & \multirow{2}{*}{$\begin{array}{r}\mathrm{N} \text { export } \\
S_{\text {threshold }} \\
\mathrm{mmol} \mathrm{m}^{-2}\end{array}$} & \multirow{2}{*}{$\begin{array}{r}\mathrm{N} \text { export } \\
\text { fraction }^{\mathrm{c}} \\
\%\end{array}$} \\
\hline & & & $\begin{array}{r}\mathrm{MLD}^{\mathrm{a}} \\
\mathrm{m}\end{array}$ & $\underset{\mathrm{m}}{T_{\min }}$ & $\begin{array}{r}S_{\text {threshold }} \\
\mathrm{m}\end{array}$ & $\begin{array}{r}\text { surface } \\
\mu \mathrm{M}\end{array}$ & $\begin{array}{r}T_{\min } \\
\mu \mathrm{M}\end{array}$ & $\begin{array}{r}S_{\text {threshold }} \\
\mu \mathrm{M}\end{array}$ & $\begin{array}{r}T_{\min } \\
\mathrm{mmol} \mathrm{m}^{-2}\end{array}$ & $\begin{array}{r}S_{\text {threshold }} \\
\mathrm{mmol} \mathrm{m}^{-2}\end{array}$ & $T_{\text {min }}^{\mathrm{b}}$ & $S_{\text {threshold }}^{\mathrm{b}}$ & & & \\
\hline A3-1 & 4 & $10-2005: 32$ & 161 & 175 & 175 & 29.1 & 31.1 & 31.1 & 268 & 268 & 5 & 5 & 138 & 130 & 49 \\
\hline TNS10 & 6 & $10-2107: 28$ & 163 & 183 & 179 & 28.9 & 31.1 & 31.0 & 298 & 270 & 5 & 5 & 193 & 77 & 28 \\
\hline TNS09 & 7 & $10-21 \quad 13: 40$ & 137 & 147 & 150 & 27.9 & 30.3 & 30.7 & 243 & 324 & 5 & 7 & 205 & 119 & 37 \\
\hline TNS08 & 8 & 10-21 18:48 & 139 & 192 & 201 & 27.9 & 30.8 & 31.2 & 362 & 470 & 6 & 7 & 179 & 291 & 62 \\
\hline TNS06 & 10 & 10-22 11:18 & 67 & $280^{\mathrm{d}}$ & 149 & 26.5 & 33.5 & 29.8 & 1034 & 317 & 11 & 7 & 219 & 99 & 31 \\
\hline TNS05 & 11 & 10-22 16:56 & 114 & $174^{\mathrm{d}}$ & 155 & 26.5 & 30.1 & 29.5 & 438 & 345 & 8 & 8 & 164 & 181 & 52 \\
\hline TNS03 & 13 & 10-23 06:41 & 111 & $191^{\mathrm{d}}$ & 164 & 26.9 & 31.0 & 29.9 & 494 & 326 & 8 & 7 & 144 & 183 & 56 \\
\hline TNS02 & 14 & 10-23 12:06 & 65 & $364^{\mathrm{d}}$ & 150 & 19.5 & 34.0 & 28.8 & 1711 & 279 & 14 & 6 & 101 & 179 & 64 \\
\hline TNS01 & 15 & 10-23 17:13 & 45 & $328^{\mathrm{d}}$ & 144 & 23.6 & 31.2 & 25.5 & 1506 & 196 & 15 & 5 & 135 & 61 & 31 \\
\hline $\mathrm{R} 2$ & 17 & $10-2522: 59$ & 111 & $184^{\mathrm{d}}$ & 168 & 25.7 & 28.0 & 27.3 & 346 & 232 & 7 & 5 & 78 & 154 & 66 \\
\hline $\mathrm{R} 2$ & 18 & $10-2601: 48$ & 123 & 193 & 167 & 26.0 & 28.3 & 27.3 & 430 & 239 & 8 & 5 & 78 & 161 & 67 \\
\hline E-1 & 27 & $10-2922: 46$ & 84 & 200 & 173 & 25.7 & 29.0 & 28.6 & 492 & 421 & 8 & 9 & 208 & 213 & 51 \\
\hline E-1 & 30 & $10-3009: 15$ & 63 & 183 & 151 & 26.0 & 29.0 & 30.8 & 293 & 493 & 6 & 11 & 208 & 285 & 58 \\
\hline TEW3 & 38 & $10-31 \quad 18: 41$ & 62 & $165^{\mathrm{d}}$ & 138 & 27.2 & 29.1 & 28.1 & 225 & 89 & 5 & 2 & 145 & -56 & -63 \\
\hline TEW4 & 42 & $11-0105: 19$ & 95 & 208 & 185 & 25.0 & 30.1 & 29.2 & 631 & 463 & 10 & 9 & 250 & 213 & 46 \\
\hline TEW5 & 44 & $11-01$ 19:00 & 60 & 173 & 174 & 26.1 & 30.2 & 29.8 & 434 & 354 & 8 & 7 & 201 & 153 & 43 \\
\hline TEW6 & 45 & 11-02 03:59 & 22 & 164 & 142 & 26.0 & 30.9 & 30.1 & 493 & 371 & 10 & 9 & 175 & 197 & 53 \\
\hline TEW7 & 46 & 11-02 09:34 & 17 & $423^{\mathrm{d}}$ & 91 & 26.0 & 35.0 & 27.0 & 2103 & 391 & 14 & 16 & 309 & 82 & 21 \\
\hline TEW8 & 47 & $11-02$ 18:47 & 22 & $293^{\mathrm{d}}$ & 75 & 19.5 & 32.7 & 27.2 & 1282 & 303 & 13 & 15 & 252 & 51 & 17 \\
\hline E-2 & 43 & $11-0112: 00$ & 42 & $210^{\mathrm{d}}$ & 157 & 18.9 & 32.7 & 29.3 & 857 & 221 & 12 & 5 & 185 & 36 & 16 \\
\hline E-3 & 50 & $11-0311: 57$ & 41 & 203 & 177 & 25.4 & 30.1 & 29.5 & 467 & 371 & 8 & 7 & 194 & 177 & 48 \\
\hline E-3 & 51 & $11-0401: 29$ & 32 & 200 & 166 & 25.8 & 30.0 & 28.7 & 486 & 253 & 8 & 5 & 194 & 59 & 23 \\
\hline E-3 & 55 & $11-04 \quad 17: 22$ & 37 & 184 & 161 & 26.0 & 29.5 & 28.6 & 520 & 361 & 10 & 8 & 194 & 166 & 46 \\
\hline F-L & 63 & $11-0621: 49$ & 21 & 182 & 79 & 26.0 & 30.5 & 26.4 & 686 & 368 & 12 & 18 & 215 & 153 & 42 \\
\hline F-S & 69 & $11-0806: 13$ & 31 & 267 & 54 & 18.9 & 35.2 & 24.7 & 1598 & 140 & 17 & 11 & 354 & -214 & -153 \\
\hline G-1 & 70 & $11-0900: 30$ & 37 & 118 & 127 & 19.9 & 29.8 & 30.3 & 380 & 447 & 11 & 12 & nd & - & - \\
\hline E-4W & 79 & $11-1108: 25$ & 67 & 158 & 147 & 23.0 & 30.2 & 30.1 & 548 & 527 & 11 & 12 & 288 & 239 & 45 \\
\hline E-4W & 81 & $11-1121: 07$ & 67 & 152 & 158 & 22.1 & 30.1 & 30.0 & 544 & 532 & 12 & 11 & 288 & 243 & 46 \\
\hline E-4W & 87 & $11-12$ 09:30 & 66 & 164 & 164 & 22.1 & 30.4 & 30.3 & 652 & 645 & 13 & 13 & 288 & 357 & 55 \\
\hline E-4E & 94 & $11-1322: 02$ & 77 & 158 & 108 & 22.1 & 28.8 & 27.7 & 382 & 236 & 8 & 8 & 253 & -17 & -7 \\
\hline E-4E & 95 & $11-14$ 01:30 & 80 & 159 & 112 & 24.1 & 28.9 & 27.4 & 439 & 227 & 10 & 7 & 253 & -26 & -11 \\
\hline A3-2 & 99 & $11-15$ 23:20 & 143 & 179 & 179 & 24.1 & 30.6 & 30.7 & 652 & 670 & 12 & 12 & 436 & 234 & 35 \\
\hline A3-2 & 108 & $11-17$ 01:08 & 123 & 182 & 177 & 25.8 & 30.9 & 30.8 & 593 & 576 & 11 & 11 & 436 & 140 & 24 \\
\hline E_4W-2 & 111 & $11-18$ 07:20 & 26 & 168 & 133 & 24.7 & 29.3 & 28.0 & 592 & 400 & 12 & 11 & 354 & 46 & 11 \\
\hline E-5 & 113 & $11-18$ 19:21 & 71 & 215 & 122 & 26.5 & 30.4 & 27.9 & 689 & 207 & 11 & 6 & 210 & -3 & -1 \\
\hline E-5 & 114 & $11-1822: 07$ & 36 & 228 & 126 & 26.5 & 30.8 & 28.0 & 756 & 206 & 11 & 6 & 210 & -4 & -2 \\
\hline E-5 & 115 & $11-1901: 30$ & 41 & $222^{\mathrm{d}}$ & 123 & 26.5 & 30.7 & 27.9 & 686 & 222 & 10 & 6 & 210 & 12 & 6 \\
\hline
\end{tabular}

${ }^{a}$ Mixed layer depth where the potential density equals potential density at $10 \mathrm{~m}+0.02 \mathrm{~kg} \mathrm{~m}^{-3}$; Park et al. (2014a).

$\mathrm{b} \%$ depletion of the winter mixed layer inventory.

${ }^{\mathrm{c}}$ Fraction equals export/depletion, calculated for the $S_{\text {threshold }}$ depletion estimate.

d No clear $T_{\min }$.

Surface data are from both the CTD Niskin bottles and underway systems. $T_{\min }$ nitrate was estimated from nearest Niskin. nd: no data.

feature, followed by the polar frontal bloom and the reference station. These methodological differences were even larger for the silicic acid depletions (Fig. 8). This analysis underlines the importance of appropriate winter nitrate (and silicic acid) surface nitrate concentration estimates to the assignment of export magnitudes.

We believe the $S_{\text {threshold }}$ approach is the most appropriate, given the observed salinity stratification, especially for the relatively weak subsurface thermal stratification observed in the Group 5 stations near the polar front, where its choice makes the most significant difference from estimates based on the $T_{\min }$ approach. This is because the high-biomass layer found in these polar frontal sites is in this shallow salinitydefined layer and because the $\mathrm{Fe}$ fertilisation of these waters is recent, as shown by their short transit time of $\sim 2$ weeks since crossing the plateau as determined from both altimetry and drifter releases (d'Ovidio et al., 2014; Park et al., 2014a). Thus the attribution of nutrient depletion below the depth of the $S_{\text {threshold }}$ to local iron-fertilised biomass production is not warranted. For all the groups, both the $T_{\mathrm{min}^{-}}$and $S_{\text {threshold }}{ }^{-}$ based nitrate depletions are relatively small as percentages of the initial upper water column inventories $(2-18 \%$; Table 4a). This reflects the early seasonal sampling, as well as a significant extent of recycling via nitrification (Dehairs et al., 2014; Lasbleiz et al., 2014). Fractional depletions of silicate were higher (3-53\%; Table 4b), consistent with the results of the autumn KEOPS expedition, which revealed low nitrate removal but near complete Si depletion (Mosseri et al., 2008). Finally, we note that we could not estimate export for the Group 4 Kerguelen Island coastal stations because neither the $T_{\min }$ nor the $S_{\text {threshold }}$ approaches were compatible with their shallow water columns.

Our preferred $S_{\text {threshold }}$ nitrate depletion estimate can be further refined by the removal of the standing stock of other nitrogen forms produced by the ecosystem (ammonium, urea, dissolved organic nitrogen (DON), particulate nitrogen) to give a better estimate of $\mathrm{N}$ export from surface waters. PN dominated these stocks, with concentrations up to $5 \mu \mathrm{M}$ (Lasbleiz et al., 2014), in contrast to ammonium, nitrite, and surface enhancements of DON (i.e. the fresh com- 
Table 4b. Surface mixed layer N depletion and export estimates.

\begin{tabular}{|c|c|c|c|c|c|c|c|c|c|c|c|c|c|c|c|}
\hline \multirow[t]{2}{*}{ Station } & \multirow{2}{*}{$\begin{array}{l}\text { CTD } \\
\text { cast }\end{array}$} & \multirow{2}{*}{$\begin{array}{r}\text { Time stamp } \\
\text { mm-dd hh-mm }\end{array}$} & \multicolumn{3}{|c|}{ Depth } & \multicolumn{3}{|c|}{ Silicate } & \multicolumn{4}{|c|}{ Silicate depletion } & \multirow{2}{*}{$\begin{array}{r}\text { BSi stock } \\
200 \mathrm{~m} \\
\mathrm{mmol} \mathrm{m}^{-2}\end{array}$} & \multirow{2}{*}{$\begin{array}{r}\text { Si export } \\
S_{\text {threshold }} \\
\mathrm{mmol} \mathrm{m}^{-2}\end{array}$} & \multirow{2}{*}{$\begin{array}{r}\text { Si export } \\
\text { fraction }^{\mathrm{c}} \\
\%\end{array}$} \\
\hline & & & $\begin{array}{r}\mathrm{MLD}^{\mathrm{a}} \\
\mathrm{m}\end{array}$ & $T_{\min }$ & $\begin{array}{r}S_{\text {threshold }} \\
\mathrm{m}\end{array}$ & $\begin{array}{r}\text { surface } \\
\mu \mathrm{M}\end{array}$ & $\begin{array}{r}T_{\min } \\
\mu \mathrm{M}\end{array}$ & $\begin{array}{r}S_{\text {threshold }} \\
\mu \mathrm{M}\end{array}$ & $\begin{array}{r}T_{\min } \\
\mathrm{mmol} \mathrm{m}^{-2}\end{array}$ & $\begin{array}{r}S_{\text {threshold }} \\
\mathrm{mmol} \mathrm{m}^{-2}\end{array}$ & $T_{\%}^{\mathrm{b}}{ }_{\%}^{\mathrm{b}}$ & $S_{\text {threshold }}^{\mathrm{b}}$ & & & \\
\hline A3-1 & 4 & $10-2005: 32$ & 161 & 175 & 175 & 10.79 & 27.12 & 27.12 & 551 & 551 & 12 & 12 & 163.5 & 388 & 70 \\
\hline TNS10 & 6 & $10-2107: 28$ & 163 & 183 & 179 & 23.27 & 30.58 & 29.71 & 1244 & 1086 & 22 & 20 & 284.5 & 802 & 74 \\
\hline TNS09 & 7 & $10-21 \quad 13: 40$ & 137 & 147 & 150 & 18.74 & 25.27 & 27.07 & 838 & 1105 & 23 & 27 & 499.1 & 606 & 55 \\
\hline TNS08 & 8 & $10-2118: 48$ & 139 & 192 & 201 & 17.03 & 22.92 & 23.70 & 884 & 1154 & 20 & 24 & 364.8 & 789 & 68 \\
\hline TNS06 & 10 & $10-2211: 18$ & 67 & $280^{\mathrm{d}}$ & 149 & 16.42 & 48.25 & 26.18 & 5896 & 1170 & 44 & 30 & 257.3 & 913 & 78 \\
\hline TNS05 & 11 & $10-22 \quad 16: 56$ & 114 & $174^{\mathrm{d}}$ & 155 & 16.98 & 27.82 & 23.48 & 1529 & 811 & 32 & 22 & 239.9 & 571 & 70 \\
\hline TNS03 & 13 & $10-2306: 41$ & 111 & $191^{\mathrm{d}}$ & 164 & 19.32 & 32.79 & 25.54 & 2092 & 806 & 33 & 19 & 209.3 & 597 & 74 \\
\hline TNSO2 & 14 & $10-2312: 06$ & 65 & $364^{\mathrm{d}}$ & 150 & 15.27 & 48.41 & 18.39 & 8116 & 307 & 46 & 11 & 127.9 & 179 & 58 \\
\hline TNS01 & 15 & $10-23 \quad 17: 13$ & 45 & $328^{\mathrm{d}}$ & 144 & 7.48 & 33.92 & 10.15 & 5875 & 243 & 53 & 17 & 33.5 & 210 & 86 \\
\hline $\mathrm{R} 2$ & 17 & $10-2522: 59$ & 111 & $184^{\mathrm{d}}$ & 168 & 12.07 & 19.54 & 17.11 & 1145 & 718 & 32 & 25 & 88.6 & 630 & 88 \\
\hline $\mathrm{R} 2$ & 18 & $10-2601: 48$ & 123 & 193 & 167 & 12.34 & 19.28 & 17.25 & 1001 & 634 & 27 & 22 & 88.6 & 546 & 86 \\
\hline E-1 & 27 & $10-2922: 46$ & 84 & 200 & 173 & 14.94 & 30.42 & 25.24 & 2426 & 1467 & 40 & 34 & 332.6 & 1134 & 77 \\
\hline E-1 & 30 & $10-3009: 15$ & 63 & 183 & 151 & 16.29 & 36.63 & 29.30 & 2794 & 1571 & 42 & 35 & 332.6 & 1238 & 79 \\
\hline TEW3 & 38 & $10-3118: 41$ & 62 & $165^{\mathrm{d}}$ & 138 & 18.63 & 26.52 & 24.23 & 893 & 547 & 20 & 16 & 141.0 & 406 & 74 \\
\hline TEW4 & 42 & $11-0105: 19$ & 95 & 208 & 185 & 14.13 & 27.73 & 23.86 & 2128 & 1359 & 37 & 31 & 460.3 & 898 & 66 \\
\hline TEW5 & 44 & $11-0119: 00$ & 60 & 173 & 174 & 14.47 & 24.81 & 24.99 & 1245 & 1276 & 29 & 29 & 145.0 & 1131 & 89 \\
\hline TEW6 & 45 & $11-02 \quad 03: 59$ & 22 & 164 & 142 & 15.83 & 28.41 & 23.92 & 1615 & 923 & 35 & 27 & 213.8 & 709 & 77 \\
\hline TEW7 & 46 & $11-0209: 34$ & 17 & $423^{\mathrm{d}}$ & 91 & 5.91 & 50.03 & 15.85 & 10392 & 557 & 49 & 39 & 326.2 & 230 & 41 \\
\hline TEW8 & 47 & $11-0218: 47$ & 22 & $293^{\mathrm{d}}$ & 75 & 6.19 & 36.81 & 16.72 & 4532 & 433 & 42 & 35 & 250.4 & 183 & 42 \\
\hline E-2 & 43 & $11-0112: 00$ & 42 & $210^{\mathrm{d}}$ & 157 & 14.52 & 38.83 & 22.79 & 3729 & 799 & 46 & 22 & 306.7 & 492 & 62 \\
\hline E-3 & 50 & $11-0311: 57$ & 41 & 203 & 177 & 15.10 & 28.92 & 24.10 & 2033 & 1117 & 35 & 26 & 285.5 & 832 & 74 \\
\hline E-3 & 51 & $11-0401: 29$ & 32 & 200 & 166 & 15.04 & 25.77 & 22.49 & 1433 & 833 & 28 & 22 & 285.5 & 548 & 66 \\
\hline E-3 & 55 & $11-04 \quad 17: 22$ & 37 & 184 & 161 & 14.81 & 29.39 & 25.69 & 1978 & 1340 & 37 & 32 & 285.5 & 1055 & 79 \\
\hline F-L & 63 & $11-0621: 49$ & 21 & 182 & 79 & 7.23 & 24.32 & 13.74 & 1688 & 373 & 38 & 34 & 313.8 & 59 & 16 \\
\hline F-S & 69 & $11-0806: 13$ & 31 & 267 & 54 & 9.88 & 39.60 & 13.42 & 4470 & 116 & 42 & 16 & 377.6 & -261 & -225 \\
\hline G-1 & 70 & $11-0900: 30$ & 37 & 118 & 127 & 9.61 & 23.99 & 26.12 & 968 & 1228 & 34 & 37 & nd & - & - \\
\hline E-4W & 79 & $11-1108: 25$ & 67 & 158 & 147 & 17.47 & 29.18 & 26.67 & 1255 & 870 & 27 & 22 & 379.5 & 490 & 56 \\
\hline E-4W & 81 & $11-1121: 07$ & 67 & 152 & 158 & 17.95 & 23.89 & 25.53 & 433 & 689 & 12 & 17 & 379.5 & 309 & 45 \\
\hline E-4W & 87 & $11-1209: 30$ & 66 & 164 & 164 & 17.00 & 26.26 & 26.26 & 1002 & 1002 & 23 & 23 & 379.5 & 622 & 62 \\
\hline E-4E & 94 & $11-1322: 02$ & 77 & 158 & 108 & 12.10 & 22.79 & 18.95 & 1034 & 520 & 29 & 25 & 427.0 & 92 & 18 \\
\hline E-4E & 95 & $11-1401: 30$ & 80 & 159 & 112 & 11.60 & 20.87 & 17.45 & 999 & 519 & 30 & 27 & 427.0 & 92 & 18 \\
\hline A3-2 & 99 & $11-15$ 23:20 & 143 & 179 & 179 & 19.82 & 27.32 & 27.32 & 1091 & 1091 & 22 & 22 & 713.3 & 378 & 35 \\
\hline A3-2 & 108 & $11-1701: 08$ & 123 & 182 & 177 & 18.60 & 28.60 & 28.16 & 1231 & 1151 & 24 & 23 & 713.3 & 438 & 38 \\
\hline E_4W-2 & 111 & $11-1807: 20$ & 26 & 168 & 133 & 9.21 & 30.44 & 22.24 & 2532 & 1297 & 49 & 44 & 744.3 & 552 & 43 \\
\hline E-5 & 113 & $11-1819: 21$ & 71 & 215 & 122 & 12.04 & 30.72 & 16.98 & 2801 & 484 & 42 & 23 & 744.3 & -260 & -54 \\
\hline E-5 & 114 & $11-1822: 07$ & 36 & 228 & 126 & 11.53 & 31.35 & 19.45 & 3139 & 707 & 44 & 29 & 744.3 & -37 & -5 \\
\hline E-5 & 115 & $11-1901: 30$ & 41 & $222^{\mathrm{d}}$ & 123 & 11.49 & 26.00 & 19.22 & 1873 & 704 & 32 & 30 & 394.4 & 310 & 44 \\
\hline
\end{tabular}

${ }^{a}$ Mixed layer depth where the potential density $=$ potential density at $10 \mathrm{~m}+0.02 \mathrm{~kg} \mathrm{~m}^{-3}$. Park et al. (2014a)

$\mathrm{b} \%$ depletion of the winter mixed layer inventory.

${ }^{\mathrm{c}}$ Fraction $=$ export/depletion, calculated for the $S_{\text {threshold }}$ depletion estimate.

d No clear $T_{\min }$. Surface data are from both the CTD Niskin bottles and underway systems. $T_{\min }$ nitrate was estimated from nearest Niskin. nd $=$ no data.

ponent) with concentrations below $1 \mu \mathrm{M}$ (Blain et al., 2014; Dehairs et al., 2014).

A few stations exhibited negative $\mathrm{N}$ export estimates because of higher PN stocks than their nitrate depletion estimates (Table 4). This could arise from either underestimation of nitrate depletions owing to entrainment of subsurface waters (an effect that can halve nutrient depletion estimates under conditions of weak water column stratification and strong winds; Wang et al., 2003) or horizontal interleaving of relatively undepleted water parcels with relatively PN-rich waters. Notably the largest excesses of PN stock over nitrate depletions occurred at stations located close to fronts (TEW3 and F-S).

Viewed at the group level, the nitrate depletions and $\mathrm{N}$ export estimates (Fig. 8) provide very useful insights. Firstly, given the uncertainties regarding the estimation of nutrient depletions from the profiles, it could be argued that the most robust conclusion is that all the groups exhibit similar depletions, with roughly half of the $\mathrm{N}$ uptake exported and half remaining as accumulated biomass. This is consistent with the growth estimates of roughly one doubling every 3 days and the satellite biomass observations indicating slower doubling approximately each week. Looking in more detail, and focusing on the salinity threshold approach, suggests that the highest nitrate depletions occurred for the Group 3 plateau stations, with significantly lower values in the Group 1 and Group 2 recirculation stations (Fig. 8 middle panel). However, the larger standing stock of PN biomass over the plateau means that the export up to the time of sampling was only slighter higher than in the Group 1 and 2 recirculation stations. This aspect is even stronger for the Si budgets, with the export of Si higher for Groups 1 and 2 than over the plateau in Group 3, emphasising the retention of $\mathrm{N}$ in comparison to Si during export.

Another interesting insight is that, in comparison to the Group 3 plateau stations, nitrate depletion and export are much lower in the Group 5 polar frontal bloom stations. Considering the $S_{\text {threshold }}$ depths (Tables $4 \mathrm{a}$ and b), and the associated Si depletion and export results (Fig. 8), helps understand why the polar frontal bloom produced less nitrogen depletion and export than the plateau bloom. Firstly, the polar frontal bloom depletion is a shallow feature compared to that 


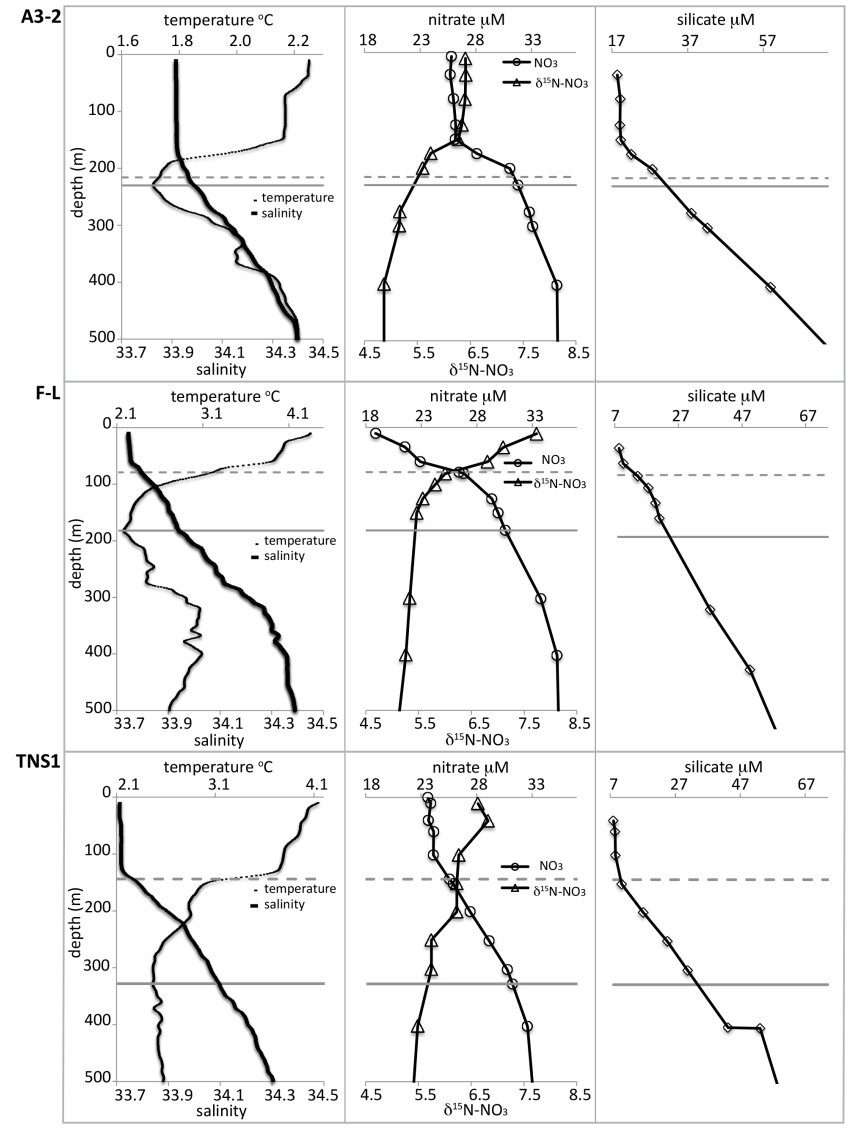

Figure 7. Example profiles of temperature, salinity, nitrate concentrations, and nitrate isotopic compositions. Top row: Group 3 central plateau station A3-2. Middle row: Group 5 downstream polar-front station F-L. Bottom row: Group 5 subantarctic station TNS-1. Depths of the remnant winter water $T_{\min }$ mixed layer depth ( $T_{\min }$ depth; solid line) and salinity stratification mixed layer depth ( $S_{\text {threshold }}$ depth; dotted lines) are shown. These depths define our two approaches for the calculation of depth-integrated nitrate and silicate depletions (Tables 4a and b; Fig. 8).

over the plateau (Fig. 7); secondly, a much greater proportion of the assimilated nitrogen is still present as standing stock (Fig. 8 bottom panel); and thirdly, there is some suggestion that more nitrogen than silicon is retained as standing stock (as a portion of depletion; compare Fig. 8, middle and bottom panels). Of course, the observation of these variations in spring does not mean that they would have persisted into summer, and it is possible that over the full season the extent of nutrient depletion was significantly different than observed during the KEOPS2 shipboard campaign, either tending towards homogeneity across the region or towards larger variations.

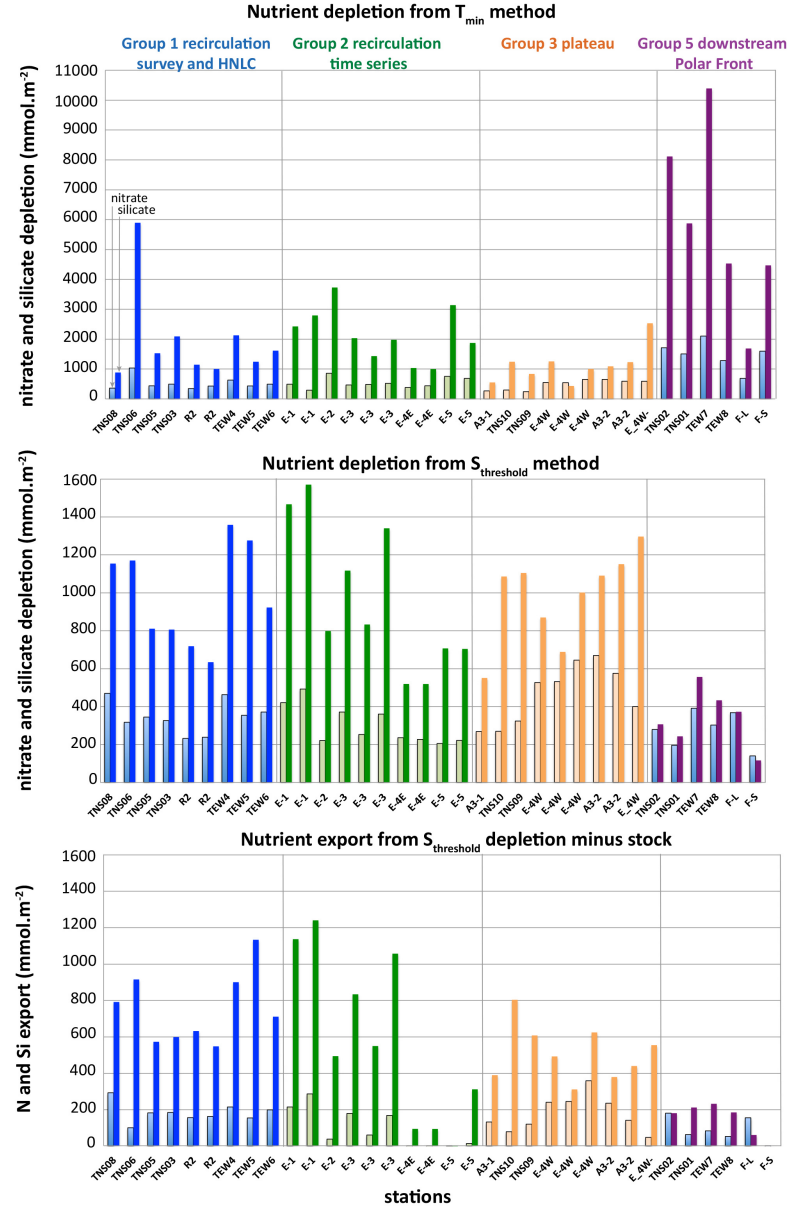

Figure 8. Nitrogen and silicon depletion and export estimates. Top row: nitrate (light bars) and silicate (dark bars) depletions from the $T_{\min }$ winter concentration method. Middle row: nitrate (light bars) and silicate (dark bars) depletions from the $S_{\text {threshold winter con- }}$ centration method. Bottom row: N (light bars) and Si (dark bars) export, as estimated from the $S_{\text {threshold }}$ depletion method, after accounting for the PN and BSi standing stocks integrated to $200 \mathrm{~m}$ (Table 4; Lasbleiz et al., 2014). Group 4 coastal stations are not shown because CTD casts could not define winter values. Negative export values are not plotted (see Tables $4 \mathrm{a}$ and $\mathrm{b}$ and text). Groups 1, 2, 3, and 4 are coloured as in Fig. 1 and are ranked from left to right with temporal order within each group.

\section{Discussion}

Our overall interest is to understand community responses to iron fertilisation, with a particular focus on the ecosystem control of nutrient depletion and carbon export. We expect this response to vary as a function of iron inputs but also possibly with time since fertilisation and its persistence (as a result of cascading trophic effects) and time of year (as a result of strong seasonality of the physical and biological background). Specific probable seasonal modulators of the response to iron include insolation, stratification, and the 
abundance of organisms with life cycles that resonate on the seasonal scale, e.g. larger zooplankton. In the following sections, we summarise the structure and function variations, relate them to temporal settings (as developed in the Methods section), and compare them to our estimates of nitrate (and silicic acid) depletion from surface waters as a proxy for carbon export.

\subsection{Overview of community structure and function variations}

Our size-fractionated chemometric parameters for microbial ecosystem structure and function identified significant differences among the various environments sampled by the KEOPS2 program. The upstream HNLC reference station (R2) displayed low phytoplankton abundance, relatively high $\mathrm{BSi}$ / POC ratios, and slow growth rates (as indicated by both strong discrimination against ${ }^{13} \mathrm{C}$ uptake (this work) and slow growth rates measured in deckboard incubations; Cavagna et al., 2014). Its ${ }^{15} \mathrm{~N}-\mathrm{PN}$ values suggested that growth was predominantly on nitrate, although this result must be viewed with caution since it differs from the surprisingly low $f$ ratio obtained by incubation (Cavagna et al., 2014). These characteristics are consistent with its selection as an HNLC reference, but the total integrated biomass was higher than the lowest values seen in Southern Ocean HNLC waters, and mesopelagic $\mathrm{Ba}$ levels indicated POC remineralisation, possibly indicating a low-level early production event (Jacquet et al., 2014; Lasbleiz et al., 2014) as a result of a small degree of Fe fertilisation, possibly from particulate-Fe inputs from the nearby Leclaire Rise (van der Merwe et al., 2014).

The moderate iron fertilisation of the recirculation feature downstream from the plateau (stations in Groups 1 and 2) increased ${ }^{13} \mathrm{C}$ model growth rates (relative to the HNLC reference station R2) by $\sim 0.02$ to $0.04 \mathrm{~d}^{-1}$ (Fig. 5) and biomass $\sim 2$-fold (increasing from $\sim 50 \%$ to 4 -fold over time; Fig. 3), particularly in the larger phytoplankton size fractions (2050 and $50-210 \mu \mathrm{m})$. There was no systematic change in $\mathrm{BSi}$ / POC ratios, with some stations showing lower values consistent with relief of iron limitation, but others showing higher values. Whether this resulted primarily from changes in species or the presence of empty frustules is unclear, although the analysis of depletions and standing stocks suggests the loss of empty frustules (as did earlier work during KEOPS; Mosseri et al., 2008). This may reflect varying levels of low production (Cavagna et al., 2014) coupled closely to export, as well as the possibility that production was in part limited by variations in mixed layer depth (Lasbleiz et al., 2014). The ${ }^{15} \mathrm{~N}-\mathrm{PN}$ observations indicated growth primarily on nitrate (as at the HNLC reference station).

Both of the more strongly iron-fertilised offshore regions (the Group 3 central plateau and the Group 5 polar-front bloom, Table 1.) exhibited increased ${ }^{13} \mathrm{C}$ model growth rates in comparison to HNLC waters (elevated by $\sim 0.05 \mathrm{~d}^{-1}$ ), but their community structures were quite different (emphasising caution regarding the ${ }^{13} \mathrm{C}$ model growth rates, although the incubation results also indicated increased growth rates; Cavagna et al., 2014). The plateau stations exhibited most of their enhanced biomass in the largest phytoplankton size fraction (50-210 $\mu \mathrm{m})$; whereas polar frontal biomass increases were dominated by the next smaller size $(20-50 \mu \mathrm{m})$. This was also true for the very strongly Fe-fertilised Group 4 coastal stations, where ${ }^{13} \mathrm{C}$ model growth rates were even more elevated (by 0.1 to $0.19 \mathrm{~d}^{-1}$ above the HNLC reference). The use of ammonium vs. nitrate (as estimated from both natural abundance ${ }^{15} \mathrm{~N}$ values in this work and tracer ${ }^{15} \mathrm{~N}$ uptake incubations by Cavagna et al., 2014) was also different between the plateau and downstream polar frontal blooms, with the plateau stations using a greater proportion of nitrate.

\subsection{Links between community structure and export}

Overall, one of the most important outcomes of our results regarding export (presented in Sect. 3.5 and Fig. 8) is that surface biomass is not a good guide to the history of export, i.e. the low-biomass recirculation feature exhibited as much export as from the higher-biomass polar-front or plateau blooms. This same conclusion was reached on the basis of sparse sediment trap deployments at $200 \mathrm{~m}$ depth (Laurenceau et al., 2014) and ${ }^{234}$ Th depletions in surface waters, which identified the recirculation feature as having the highest $\mathrm{C}$ exports of all regions (Planchon et al., 2014).

The cause of the low export, at $200 \mathrm{~m}$ depth, from the polar-front bloom (Group 5 downstream stations) may in part be the shallowness of its high-biomass surface layer, only $\sim$ half that of the recirculation feature and plateau (Lasbleiz et al., 2014; Laurenceau et al., 2014), allowing for more remineralisation before export through the $200 \mathrm{~m}$ depth horizon. The cause of the high export from the low-biomass recirculation feature is less easy to understand - it suggests that production (also found to be moderately high in these waters compared to the other regions; Cavagna et al., 2014) and export have been in close balance in these waters. This is a phenomenon often found in association with small phytoplankton-dominated communities and attributed to tight coupling with small grazers (Boyd and Newton, 1999; Cullen, 1995). Our observations show that this tight coupling also persisted as very large, moderately to heavily silicified diatoms (Fig. 3) became dominant. This suggests that tight coupling may have also been achieved for the larger phytoplankton. Notably there were abundant large herbivorous zooplankton in the recirculation region (Carlotti et al., 2014), and large faecal pellets as well as diatom aggregates were important contributors to export, based on observations in polyacrylamide-gel-filled sediment traps (Laurenceau et al., 2014). In making these comparisons among the station groups, it is of course important to remember that our observations of nutrient depletion and export apply only at the this early spring observation time, and the subsequent evolution 
of the different water parcels may lead to different outcomes when averaged over the full annual cycle.

\subsection{Influence of fertilisation time and persistence on ecosystem responses}

As developed in the Methods section, we consider four possible relative indices for the nature of the Fe fertilisation and the overall ecosystem responses:

1. intensity of $\mathrm{Fe}$ fertilisation (lowest to highest): recirculation feature < plateau $<\approx$ polar-front plume $<<$ coastal stations;

2. elapsed time since Fe fertilisation and its persistence (most recent to oldest): polar-front plume $<$ recirculation feature $\approx$ plateau $<$ coastal stations;

3. magnitude of biomass accumulation (lowest to highest, at end of voyage): recirculation feature < coastal stations $<$ plateau $<\approx$ polar-front plume;

4. elapsed time since initiation of biomass accumulation (most recent to oldest): recirculation feature < polarfront plume $<\approx$ plateau $<<$ coastal stations.

If we put aside the coastal stations, where depletion and export could not be estimated, we can ask which of these might explain why the recirculation feature achieved high export in comparison to its low to moderate biomass and low to moderate intensity of iron fertilisation. Index (ii) emerges as the most likely candidate - the recirculation feature receives low-intensity ongoing iron fertilisation as a result of the recirculation of waters along the polar front and into it from the northeast (d'Ovidio et al., 2014), with possible augmentations from shallow Ekman transport from the nearby Kerguelen Shelf (d'Ovidio et al., 2014; Sanial et al., 2014). This is a fascinating possibility because it suggests ecosystems are modulated differently by persistent as opposed to punctual inputs of Fe.

Indices (i) and (iv) also list the recirculation as an endmember, but it seems unlikely that low Fe levels or low biomass are drivers of high export, given that many studies of export have found positive correlations with biomass, though with significant modulation by community structure (e.g. Boyd and Newton, 1995, 1999; Boyd and Trull, 2007; Buesseler, 1998; Buesseler et al., 2001, 2007).

Do any of these indices also provide insight into why the community differs between the two strongly iron-fertilised regions (the central plateau vs. the downstream polar front)? For size structure, none of the time perspectives (indices iiiv) appears to help - the plateau and recirculation features with their dominance by very large diatoms (vs. the more balanced size structure of the coastal and downstream polarfront bloom) do not fall appropriately along any of the time spectrums of these three "clocks". To the extent that the intensity of iron fertilisation (index i) may have been higher in both coastal and polar-front waters than over the plateau, despite similar current Fe levels (see the Methods section for discussion), this could provide an explanation, but it would imply that more Fe produces communities with smaller cells, and it would thus be counter to the results of artificial iron experiments (Boyd, P. et al., 1999; Boyd et al., 2007). This leaves us with the strong possibility that the community structure differences between the plateau and polar-front regions derive in part from other factors beyond levels, timing, or persistence of iron fertilisation.

\section{Conclusions}

A complex mosaic of phytoplankton blooms forms in response to natural iron fertilisation from the Kerguelen Plateau. Community structure variations in the downstream waters appear to have multiple influences, including the intensity and persistence of iron fertilisation, the progress of biomass accumulation, and possibly whether they were sourced from plateau vs. coastal waters. These differences developed even though phytoplankton growth rates appeared to increase more directly with the level of iron availability, pointing to additional influences from trophodynamics. These community effects strongly decoupled levels of surface biomass from levels of particle export to the ocean interior over the timescales of spring bloom development studied here. 


\section{Appendix A: Chemical and isotopic analyses}

\section{A1 Particle collection}

The ship supply collected water from $\sim 7 \mathrm{~m}$ depth via a $10 \mathrm{~cm}$ diameter plastic hose extended through a vertical stainless-steel stand pipe protruding $\sim 1 \mathrm{~m}$ below the ship's forward hull. A sealed rotary propeller pump drew the supply through a $1000 \mu \mathrm{m}$ nylon cylindrical pre-filter and distributed it via a manifold at more than $50 \mathrm{~L} \mathrm{~min}^{-1}$, with most water returned over the side. This pre-filter was cleaned before each sample, and then a manifold valve was opened to supply a smaller flow of $8-10 \mathrm{~L} \mathrm{~min}^{-1}$ through our small-volume bulk particle and large-volume sequential filtration systems. The large-volume size fractionation system passes the water through a $47 \mathrm{~mm}$ diameter $1000 \mu \mathrm{m}$ screen (to remove any large particles that managed to pass through the pump prefilter at higher flow rates), followed by $142 \mathrm{~mm}$ diameter $\mathrm{Ni}$ tex nylon screens $(300,210,50,20$, and $5 \mu \mathrm{m}$ mesh sizes) and a final $142 \mathrm{~mm}$ diameter QMA quartz fibre filter $(1 \mu \mathrm{m}$ nominal pore size, Sartorius). The small-volume bulk enclosed sample system rapidly fills a precisely known $\sim 1 \mathrm{~L}$ volume and low-pressure filters it through a QMA quartz filter (muffled and pre-loaded under clean conditions into in-line filter holders). Quartz filters were used in preference to glass to minimise ${ }^{234} \mathrm{Th}$ backgrounds and to give better combustion characteristics during elemental and isotopic analysis. The flow path allowed a higher flow rate through the larger meshes (Table 2). The very minor amounts of material on the $1000 \mu \mathrm{m}$ screen were not analysed. Particles on the other nylon screens were immediately resuspended ( $1 \mu \mathrm{m}$ filtered seawater from the sampling location) and refiltered onto $25 \mathrm{~mm}$ diameter, 1.2 micron pore size silver membrane filters (Sterlitech) and, along with the QMA filter (Sartorius T293), were dried at $60^{\circ} \mathrm{C}$. Following drying, the particles were examined under stereomicroscopy onboard the ship at a magnification of up to 50 and then analysed non-destructively onboard for ${ }^{234} \mathrm{Th}$ activities (Planchon et al., 2014). All other analyses were carried out in the Hobart laboratories.

\section{A2 Particle analyses}

Biogenic silica (BSi), particulate organic carbon (POC), and particulate nitrogen (PN), $\delta^{13} \mathrm{C}-\mathrm{POC}$, and $\delta^{15} \mathrm{~N}-\mathrm{PN}$ analyses were carried out in Hobart. For BSi, a single $5 \mathrm{~mm}$ diameter punch of the silver filters was analysed using an approach used previously for Southern Ocean samples (Queguiner, 2001). The biogenic silica was dissolved by adding $4 \mathrm{~mL}$ of $0.2 \mathrm{M} \mathrm{NaOH}$ and incubating it at $95^{\circ} \mathrm{C}$ for $90 \mathrm{~min}$. Samples were then rapidly cooled to $4{ }^{\circ} \mathrm{C}$ and $1 \mathrm{~mL}$ of $1 \mathrm{M} \mathrm{HCl}$ was added. Thereafter, samples were centrifuged at $1880 \times g$ for 10 min and the supernatant was transferred to a new tube and diluted with artificial seawater $\left(36 \mathrm{~g} \mathrm{~L}^{-1} \mathrm{NaCl}\right)$. Biogenic silica concentrations were determined by spectrophotometry using an Alpkem model 3590 segmented flow analyser and following USGS Method I-2700-85 with these modifications: ammonium molybdate solution contained $10 \mathrm{~g} \mathrm{~L}^{-1}$ $\left(\mathrm{NH}_{4}\right)_{6} \mathrm{Mo}_{7} \mathrm{O}_{24}, 800 \mu \mathrm{L}$ of $10 \%$ sodium dodecyl sulfate detergent replaced Levor IV solution, acetone was omitted from the ascorbic acid solution, and artificial seawater was used as the carrier solution. Biogenic silica standard concentrations were $0,28,56,84,112$, and $140 \mu \mathrm{M}$. Standard curves across all runs had an average slope of $48438 \pm 454$ (1 s.d. $n=4)$. The mean concentration of repeated check standards $(140 \mu \mathrm{M})$ was $139.85, \pm 0.31 \mu \mathrm{M}(n=68)$. The average blank value was $0.009 \pm 0.006 \mu$ moles punch ${ }^{-1}(1 \mathrm{SD}$ $n=5$ ), equating to $0.08 \%$ of the mean of $50 \mu \mathrm{m}$ fraction samples (highest concentrations) and $1.22 \%$ of the mean of $300 \mu \mathrm{m}$ fractions (lowest concentrations).

For the POC and PN analyses, $3 \times 5 \mathrm{~mm}$ punched subsamples of the $25 \mathrm{~mm}$ diameter silver membrane filters were placed in acid-resistant silver capsules (Sercon SC0037), treated with two $10 \mu \mathrm{L}$ aliquots of $2 \mathrm{~N} \mathrm{HCl}$ (and $2 \times 20 \mu \mathrm{L}$ for the bulkier QMA filter subsamples, $5 \times 5 \mathrm{~mm}$ punches) to remove carbonates (King et al., 1998), and dried at $60^{\circ} \mathrm{C}$. A first set of subsamples was analysed for POC and PN concentrations by the combustion of the encapsulated samples in a Thermo-Finnigan Flash 1112 elemental analyser with reference to sulfanilamide standards in the Central Sciences Laboratory of the University of Tasmania. Precision of the analyses was $\sim 1 \%$, but the overall precision was limited to $5-10 \%$ by the subsampling of the filters that often had patchy or uneven coverage. Based on the POC and PN results, a third set of subsamples was punched for isotopic analyses with the number of punches adjusted to ensure similar voltages within the dynamic range of the spectrometer.

$\delta^{13} \mathrm{C}$-POC and $\delta^{15} \mathrm{~N}-\mathrm{PN}$ on the silver filters were analysed separately using a Fisons NA1500 Elemental Analyser coupled via a Con-flow IV interface to a Finnigan Delta $\mathrm{V}^{\text {PLUS }}$ isotope ratio mass spectrometer at CSIRO Marine and Atmospheric Research with separate oxidation and reduction columns installed. For the QMA filters, a Flash 2000 EA1112 HT Thermoscientific was fitted with a single combined oxidation and reduction column, with dead spaces minimised for improved precision at $<20 \mu \mathrm{g} \mathrm{N}$. During all ${ }^{15} \mathrm{~N}$ analyses, $\mathrm{CO}_{2}$ was removed using a sodium hydroxide scrubber (self-indicating Ascarite 2, Thomas Scientific) to avoid $\mathrm{CO}^{+}$interference at $\mathrm{m} / z 29$ and 28 (Brooks et al., 2003). The $\delta^{15} \mathrm{~N}$ and $\delta^{13} \mathrm{C}$ isotopic compositions are expressed in delta notation vs. atmospheric $\mathrm{N}_{2}$ and the VPDB standard, respectively. Standardisation was by reference to $\mathrm{CO}_{2}$ and $\mathrm{N}_{2}$ working gases injected before and after each sample, with normalisation to solid reference materials inserted (along with blank cups) after each of the six samples. For $\delta^{13} \mathrm{C}$, the solid standards were NBS-22 oil (RM8539, -29.73\%o), NBS-19 (limestone, RM8544, $+1.95 \%$ ) , and casein (Protein Standard OAS B2155 batch 114859, Elemental Microanalysis, $\delta^{13} \mathrm{C}+5.94$ and $\delta^{15} \mathrm{~N}$ -26.98). For $\delta^{15} \mathrm{~N}$, the solid standards were IAEA-N1 (ammonium sulfate, RM8547, $+0.43 \%$ ), IAEA-N3 (potassium 
nitrate, RM8549, $+4.72 \%$ ), and casein (as above). Based on replicate analyses of these standards, the estimated precisions were typically $0.1 \%$ or 1 standard deviation for both $\delta^{13} \mathrm{C}(n=15)$ and $\delta^{15} \mathrm{~N}(n=20)$.

Sample replicates generally had comparable precisions to the reference materials, but filters with patchy coverage had lower precision $(0.3 \%$ in the worst cases, presumably reflecting isotopic heterogeneity within the size fractions). In addition, a small correction of $<+0.4 \%$ was made to the QMA filter results after indirect estimation of the blank $\delta^{13} \mathrm{C}$ at -29.6 (Avak and Fry, 1999), at $\sim 10 \%$ of the sample signal strength. Procedural blanks were measured by passing $1 \mathrm{~L}$ of seawater through the onboard pumping system and by subsequently processing it in parallel to the samples; this yielded negligible amounts of POC and PN (<1\% of typical samples), with ratios close to those of the samples, and no correction was applied.

\section{A3 Dissolved component analyses}

Underway nitrate concentrations were mapped using an InSitu Ultraviolet nitrate Sensor (ISUS-V3, Satlantic), calibrated three times during the voyage against seawater nitrate standards $(\sim 15,20,25,30 \mu \mathrm{M})$, with additional comparisons to nitrate samples collected from the underway supply at every station sampled for particle analyses, yielding a precision of $\sim 1.5 \mu \mathrm{M}$. Nitrate concentrations for these samples and the CTD-Niskin bottles were measured onboard using a segmented flow spectrometric autoanalyser, with a precision of $\sim 0.1 \mu \mathrm{M}$. The $\mathrm{N}$ and $\mathrm{O}$ isotopic compositions of dissolved nitrate were measured via its bacterial conversion to nitrate to nitrous oxide followed by isotope ratio mass spectrometry at the Vrije Universitait Bruxelles, with a precision of approximately $0.2 \%$ or for ${ }^{15} \mathrm{~N}-\mathrm{NO}_{3}$ and of $0.4 \%$ or ${ }^{18} \mathrm{O}$ $\mathrm{NO}_{3}$ (further analytical details are provided in Dehairs et al., 2014).
Samples for the measurement of the carbon isotopic composition of dissolved inorganic carbon were collected in $10 \mathrm{~mL}$ Exetainer vials, with airtight septa, by filling the tubes from the QMA-filtered $(\sim 0.8 \mu \mathrm{m})$ underway supply and preserving them by addition of $20 \mu \mathrm{L}$ of saturated mercuric chloride. $1 \mathrm{~mL}$ aliquots were withdrawn and injected into acid-washed, helium-flushed Exetainer tubes. $100 \mu \mathrm{L}$ of orthophosphoric acid (99\%, Fluka) was injected and the headspace equilibrated at $25^{\circ} \mathrm{C}$ for $18 \mathrm{~h}$ (modification of Assayag et al., 2006). Solid NBS19 $\mathrm{CaCO}_{3}$ (200 to $230 \mu \mathrm{g}$, $\delta^{13} \mathrm{C}=+1.98, n=10$ standard deviation 0.02 ), and bulk quality assurance sediment trap material $(1200 \mu \mathrm{g}, 12.9 \%$ $\mathrm{CaCO}_{3}, \delta^{13} \mathrm{C}=+2.9$ ), was weighed into smooth wall tin capsules $(5 \times 5.5 \mathrm{~mm} \mathrm{SC1190,} \mathrm{Sercon})$ and lowered into the Exetainer tubes and purged; then $1 \mathrm{~mL}$ of DIC free seawater was added before proceeding as for the samples. Blank, standard, and sample headspaces (one standard after each of the five samples) were sampled using a Finnigan GasBench2 (Thermoscientific) fitted with a $100 \mu \mathrm{L}$ sample loop. The headspace gases from the gas bench were analysed (continuous flow) by the DeltaV ${ }^{\text {Plus }}$ isotope ratio mass spectrometer and Isodat 3 software at CSIRO Marine and Atmospheric Research. 


\section{The Supplement related to this article is available online at doi:10.5194/bg-12-1029-2015-supplement.}

Acknowledgements. The Institute Polaire Paul-Emile Victor, the captain and crew of the Marion Dufresne, the Australian Commonwealth Cooperative Research Centre Program, and CSIRO Marine and Atmospheric Research (CMAR) provided logistic and financial support. Special thanks go to Pierre Sangiardi (IPEV) for implementing the underway seawater supply for our high-volume particle sampling and underway sensor mapping; Louise Oriole (Laboratoire d'Océanographie Microbienne, Banyuls sur mer, France) for shipboard nutrient analyses; Abraham Passmore (ACE CRC) for BSi analyses; Peter Jansen (IMOS) for the logging system for the underway ISUS ultraviolet nitrate sensor; Ben Weeding (IMOS) for advancing ISUS calibration; Thomas Rodemann for CHN analyses in the University of Tasmania Central Sciences Laboratory; the VUB for nitrate isotope analyses; Clair Lo Monoco and Nicolas Metzl (LOCEAN, UPMC-CNRS) for access to $p \mathrm{CO}_{2}$ results; and Andy Bowie (ACE CRC/UTAS), Pier van der Merwe (ACE CRC), and Fabien Queroue (UTAS/UBO) for access to iron results. This work was supported by the French Research program of INSU-CNRS LEFE-CYBER (Les enveloppes fluides et l'environnement-Cycles biogéochimiques, environnement et ressources), the French ANR (Agence Nationale de la Recherche, SIMI-6 program, ANR-10-BLAN-0614), and the French CNES (Centre National d'Etudes Spatiales).

Edited by: I. Obernosterer

\section{References}

Anderson, L. and Sarmiento, J.: Redfield ratios of remineralization determined by nutrient data analysis, Global Biogeochem. Cy., 8, 65-80, 1994.

Armstrong, R. A.: An optimization-based model of iron-lightammonium colimitation of nitrate uptake and phytoplankton growth, Limnol. Oceanogr., 44, 1436-1446, 1999.

Arrigo, K. R., Robinson, D. H., Worthen, D. L., Dunbar, R. B., DiTullio, G. R., VanWoert, M., and Lizotte, M. P.: Phytoplankton community structure and the drawdown of nutrients and $\mathrm{CO}_{2}$ in the Southern Ocean, Science, 283, 365-367, 1999.

Assmy, P., Smetacek, V., Montresor, M., Klaas, C., Henjes, J., Strass, V. H., Arrieta, J. M., Bathmann, U., Berg, G. M., and Breitbarth, E.: Thick-shelled, grazer-protected diatoms decouple ocean carbon and silicon cycles in the iron-limited Antarctic Circumpolar Current, P. Natl. Acad. Sci., 110, 20633-20638, 2013.

Avak, H. and Fry, B.: EA-IRMS: Precise and accurate measurement of d $15 \mathrm{~N}$ on < 10ug N, Finnigan MAT Application flash report G29, 1-4, 1999.

Blain, S., Queguiner, B., and Trull, T.: The natural iron fertilization experiment KEOPS (KErguelen Ocean and Plateau compared Study): An overview, Deep-Sea Res.-Pt. II, 55, 559-565, doi:10.1016/j.dsr2.2008.01.002, 2008.

Blain, S., Capparos, J., Guéneuguès, A., Obernosterer, I., and Oriol, L.: Distributions and stoichiometry of dissolved nitro- gen and phosphorus in the iron fertilized region near Kerguelen (Southern Ocean), Biogeosciences Discuss., 11, 9949-9977, doi:10.5194/bgd-11-9949-2014, 2014.

Bowie, A. R., van der Merwe, P., Quéroué, F., Trull, T., Fourquez, M., Planchon, F., Sarthou, G., Chever, F., Townsend, A. T., Obernosterer, I., Sallée, J.-B., and Blain, S.: Iron budgets for three distinct biogeochemical sites around the Kerguelen archipelago (Southern Ocean) during the natural fertilisation experiment KEOPS-2, Biogeosciences Discuss., 11, 17861-17923, doi:10.5194/bgd-11-17861-2014, 2014.

Boyd, P., Watson, A., Law, C. S., Abraham, E., Trull, T., and Murdoch, R.: SOIREE - A Southern Ocean iron release experiment elevates phytoplankton stocks in Polar waters, EOS Trans, AGU Ocean Sciences Meet. Suppl., 80, OS30, 1999.

Boyd, P. W. and Newton, P.: Evidence of the potential influence of planktonic community structure on the interannual variability of particulate carbon flux, Deep-Sea Res.-Pt. I, 42, 619-639, 1995.

Boyd, P. W. and Newton, P.: Does planktonic community structure determine downward particulate organic carbon flux in different oceanic provinces?, Deep-Sea Res.-Pt. I, 46, 63-91, 1999.

Boyd, P. W. and Trull, T. W.: Understanding the export of marine biogenic particles: is there consensus?, Progr. Oceanogr., 4, 276312, doi:10.1016/j.pocean.2006.1010.1007, 2007.

Boyd, P. W., Jickells, T., C. S. Law, Blain, S., Boyle, E. A., Buesseler, K. O., Coale, K. H., Cullen, J. J., Baar, H. J. W. d., Follows, M., Harvey, M., Lancelot, C., Levasseur, M., Owens, N. P. J., Pollard, R., Rivkin, R. B., Sarmiento, J., Schoemann, V., Smetacek, V., Takeda, S., Tsuda, A., Turner, S., and Watson, A. J.: Mesoscale Iron Enrichment Experiments 19932005: Synthesis and Future Directions, Science, 315, 612-617, doi:10.1126/science.1131669, 2007.

Brooks, P. D., Geilmann, H., Werner, R. A., and Brand, W. A.: Improved precision of coupled $13 \mathrm{C}$ and $15 \mathrm{~N}$ measurements from single samples using an elemental analyser, Rapid Communications in Mass Spectroscopy, 17, 1924-1926, 2003.

Buesseler, K. O.: The decoupling of production and particulate export in the surface ocean, Global Biogeochem. Cy., 12, 297-310, 1998.

Buesseler, K. O., Ball, L., Andrews, J. E., Cochran, J. K., Hirschberg, D. J., Bacon, M. P., Fleer, A., and Brzezinski, M.: Upper ocean export of particulate organic carbon and biogenic silica in the Southern Ocean along $170^{\circ} \mathrm{W}$, Deep-Sea Res.-Pt. II, 48, 4275-4297, 2001.

Buesseler, K. O., Lamborg, C. H., Boyd, P. W., Lam, P. J., Trull, T. W., Bidigare, R. R., Bishop, J. K. B., Casciotti, K. L., Dehairs, F., Elskens, M., Honda, M., Karl, D. M., Siegel, D., Silver, M., Steinberg, D., Valdes, J., Van Mooy, B., and Wilson, S. E.: Revisiting carbon flux through the Ocean's twilight zone, Science, 316, 567-570, doi:10.1126/science.1137959, 2007.

Burkhardt, S., Riebesell, U., and Zondervan, I.: Effects of growth rate, $\mathrm{CO}_{2}$ concentration, and cell size on the stable carbon isotope fractionation in marine phytoplankton, Geochim. Cosmochim. Ac., 63, 3729-3741, 1999a.

Burkhardt, S., Riebesell, U., and Zondervan, I.: Effects of growth rate, $\mathrm{CO}_{2}$ concentration, and cell size on the stable carbon isotope fractionation in marine phytoplankton, Geochim. Cosmochim. Ac., 63, 3729-3741, 1999b.

Burkhardt, S., Riebesell, U., and Zondervan, I.: Stable carbon isotope fractionation by marine phytoplankton in response to 
daylength, growth rate, and $\mathrm{CO}_{2}$ availability, Marine ecologyprogress series, 184, 31-41, 1999c.

Carlotti, F., Jouandet, M.-P., Nowaczyk, A., Harmelin-Vivien, M., Lefèvre, D., Guillou, G., Zhu, Y., and Zhou, M.: Mesozooplankton structure and functioning during the onset of the Kerguelen phytoplankton bloom during the Keops2 survey, Biogeosciences Discuss., 12, 2381-2427, doi:10.5194/bgd-12-2381-2015, 2015.

Cavagna, A. J., Fripiat, F., Elskens, M., Dehairs, F., Mangion, P., Chirurgien, L., Closset, I., Lasbleiz, M., Flores-Leiva, L., Cardinal, D., Leblanc, K., Fernandez, C., Lefèvre, D., Oriol, L., Blain, S., and Quéguiner, B.: Biological productivity regime and associated $\mathrm{N}$ cycling in the vicinity of Kerguelen Island area, Southern Ocean, Biogeosciences Discuss., 11, 18073-18104, doi:10.5194/bgd-11-18073-2014, 2014.

Chisholm, S. W.: Phytoplankton size, in: Primary productivity and biogeochemical cycles in the sea, edited by: Falkowski, P. and Woodhead, A., Envir. Sci. R., Springer, 213-237, 1992.

Christaki, U., Lefèvre, D., Georges, C., Colombet, J., Catala, P., Courties, C., Sime-Ngando, T., Blain, S., and Obernosterer, I.: Microbial food web dynamics during spring phytoplankton blooms in the naturally iron-fertilized Kerguelen area (Southern Ocean), Biogeosciences Discuss., 11, 6985-7028, doi:10.5194/bgd-11-6985-2014, 2014.

Cózar, A. and Echevarría, F.: Size structure of the planktonic community in microcosms with different levels of turbulence, Sci. Mar., 69, 187-197, 2005.

Craig, H.: The geochemistry of the stable carbon isotopes, Geochim. Cosmochim. Ac., 3, 53-92, 1953.

Cullen, J. J.: Status of the iron hypothesis after the Open-Ocean Enrichment Experiment, Limnol. Oceanogr., 40, 1336-1343, 1995.

de Baar, H. J. W., de Jong, J. T. M., Bakker, D. C. E., Loscher, B. M., Veth, C., Bathmann, U., and Smetacek, V.: Importance of iron for phytoplankton blooms and carbon dioxide drawdown in the Southern Ocean, Nature, 373, 412-415, 1995.

Dehairs, F., Fripiat, F., Cavagna, A.-J., Trull, T. W., Fernandez, C., Davies, D., Roukaerts, A., Fonseca Batista, D., Planchon, F., and Elskens, M.: Nitrogen cycling in the Southern Ocean Kerguelen Plateau area: evidence for significant surface nitrification from nitrate isotopic compositions, Biogeosciences Discuss., 11, 13905-13955, doi:10.5194/bgd-11-13905-2014, 2014.

d'Ovidio, F., Della Penna, A., Trull, T. W., Nencioli, F., Pujol, I., Rio, M. H., Park, Y.-H., Cotté, C., Zhou, M., and Blain, S.: The biogeochemical structuring role of horizontal stirring: Lagrangian perspectives on iron delivery downstream of the Kerguelen plateau, Biogeosciences Discuss., 12, 779-814, doi:10.5194/bgd-12-779-2015, 2015.

Farquhar, G. D., O'Leary, M. H., and Berry, J. A.: On the relationship between carbon isotope discrimination and the intracellular carbon dioxide concentration in leaves, Aust. J. Plant Physiol., 9, 121-137, 1982.

Fontugne, M., Descolas-Gros, C., and de Billy, G.: The dynamics of $\mathrm{CO}_{2}$ fixation in the Southern Ocean as indicated by carboxylase activities and organic carbon isotope ratios, Mar. Chem., 35, 371-380, 1991.

Georges, C., Monchy, S., Genitsaris, S., and Christaki, U.: Protist community composition during early phytoplankton blooms in the naturally iron-fertilized Kerguelen area (Southern Ocean), Biogeosciences Discuss., 11, 11179-11215, doi:10.5194/bgd11-11179-2014, 2014.
Gervais, F. and Riebesell, U.: Effect of phosphorus limitation on elemental composition and stable carbon isotope fractionatiaon in a marine diatoms growing under different $\mathrm{CO}_{2}$ concentrations., Limnol. Oceanogr., 46, 497-504, 2001.

Goericke, R., Montoya, J. P., and Fry, B.: Physiology of isotopic fractionation in algae and cyanobacteria, in: Stable Isotopes in Ecology and Environmental Science, edited by: Lajtha, K. and Michener, R. H., Blackwell Scientific Publications, Oxford, 1870-1221, 1994.

Hoffmann, L. J., Peeken, I., and Lochte, K.: Effects of iron on the elemental stoichiometry during EIFEX and in the diatoms Fragilariopsis kerguelensis and Chaetoceros dichaeta, Biogeosciences, 4, 569-579, doi:10.5194/bg-4-569-2007, 2007.

Hutchins, D. A. and Bruland, K. W.: Iron limited diatom growth and $\mathrm{Si}: \mathrm{N}$ uptake ratios in a coastal upwelling regime, Nature, 393, 561-564, 1998.

Jacquet, S. H. M., Dehairs, F., Cavagna, A. J., Planchon, F., Monin, L., André, L., Closset, I., and Cardinal, D.: Early season mesopelagic carbon remineralization and transfer efficiency in the naturally iron-fertilized Kerguelen area, Biogeosciences Discuss., 11, 9035-9069, doi:10.5194/bgd-11-9035-2014, 2014.

Karsh, K. L., Trull, T. W., Lourey, A. J., and Sigman, D. M.: Relationship of nitrogen isotope fractionation to phytoplankton size and iron availability during the Southern Ocean Iron RElease Experiment (SOIREE), Limnol. Oceanogr., 48, 1058-1068, 2003.

Karsh, K. L., Trull, T. W., Sigman, D. M., Thompson, P. A., and Granger, J.: The contributions of nitrate uptake and efflux to isotope fractionation during algal nitrate assimilation, Geochim. Cosmochim. Ac., 132, 391-412, doi:10.1016/j.gca.2013.09.030, 2014.

Keller, K. and Morel, F. M. M.: A model of carbon isotopic fractionation and active carbon uptake in phytoplankton, Mar. Ecol.Prog. Ser., 182, 295-298, 1999.

King, P., Kennedy, H., Newton, P., Jickells, T., Brand, T., Calvert, S., Cauwet, G., Etcheber, H., Head, B., Khripounoff, A., Manighetti, B., and Miquel, J. C.: Analysis of total and organic carbon and total nitrogen in settling oceanic particles and marine sediment: an interlaboratory comparison, Mar. Chem., 60, 203-216, 1998.

Lasbleiz, M., Leblanc, K., Blain, S., Ras, J., Cornet-Barthaux, V., Hélias Nunige, S., and Quéguiner, B.: Pigments, elemental composition $(\mathrm{C}, \mathrm{N}, \mathrm{P}$, and $\mathrm{Si}$ ), and stoichiometry of particulate matter in the naturally iron fertilized region of Kerguelen in the Southern Ocean, Biogeosciences, 11, 5931-5955, doi:10.5194/bg-115931-2014, 2014.

Laurenceau, E. C., Trull, T. W., Davies, D. M., Bray, S. G., Doran, J., Planchon, F., Carlotti, F., Jouandet, M.-P., Cavagna, A.J., Waite, A. M., and Blain, S.: The relative importance of phytoplankton aggregates and zooplankton fecal pellets to carbon export: insights from free-drifting sediment trap deployments in naturally iron-fertilised waters near the Kerguelen plateau, Biogeosciences Discuss., 11, 13623-13673, doi:10.5194/bgd11-13623-2014, 2014.

Laws, E. A., Popp, B. N., Bidigare, R. R., Kennicutt, M. C., and Macko, S. A.: Dependence of phytoplankton carbon isotopic composition on growth rate and $\left[\mathrm{CO}_{2}\right]_{\mathrm{aq}}$ : Theoretical considerations and experimental results, Geochim. Cosmochim. Ac., 59, 1131-1138, 1995.

Laws, E. A., Popp, B. N., Cassar, N., and Tanimoto, J.: 13C discrimination patterns in oceanic phytoplankton: likely influence 
of $\mathrm{CO}_{2}$ concentrating mechanisms, and implications for palaeoreconstructions, Funct. Plant Biol., 29, 323-333, 2002.

Leynaert, A., Bucciarelli, E., Claquin, P., Dugdale, R. C., MartinJézéquel, V., Pondaven, P., and Ragueneau, O.: Effect of iron deficiency on diatom cell size and silicic acid uptake kinetics, Limnol. Oceanogr., 49, 1134-1143, 2004.

Lo Monaco, C., Metzl, N., D’Ovidio, F., Llort, J., and Ridame, C.: Rapid establishment of the $\mathrm{CO}_{2}$ sink associated with Kerguelen's bloom observed during the KEOPS2/OISO20 cruise, Biogeosciences Discuss., 11, 17543-17578, doi:10.5194/bgd11-17543-2014, 2014

Maldonado, M. T., Boyd, P. W., Abraham, E., Bowie, A., Croot, P., Strzepek, R., Waite, A., LaRoche, J., Frew, R., and Price, N.: Iron uptake and physiological response of phytoplankton during a mesoscale Southern Ocean Iron enrichment, Limnol. Oceanogr., 46, 1802-1808, 2001.

Marchetti, A. and Cassar, N.: Diatom elemental and morphological changes in response to iron limitation: a brief review with potential paleocenaographic applications, Geobiology, 7, 419-431, 2009

Michener, R. H. and Schell, D. M.: Stable isotope ratios as tracers in marine aquatic food webs, in: Stable isotopes in ecology and environmental science, edited by: Lajtha, K. and Michener, R. H., Blackwell Scientific Publications, Oxford, 138-157, 1994.

Morel, F. M. M., Reuter, J. G., and Price, N. M.: Iron nutrition of phytoplankton and its possible importance in the ecology of ocean regions with high nutrient and low biomass, Oceanography, 4, 56-61, 1991.

Mosseri, J., Quéguiner, B., Armand, L., and Cornet-Barthaux, V.: Impact of iron on silicon utilization by diatoms in the Southern Ocean: a case study of the $\mathrm{Si} / \mathrm{N}$ cycle decoupling in a naturally iron-enriched area, Deep-Sea Res.-Pt. II, 55, 801-819, 2008.

Park, Y.-H., Roquet, F., Fuda, J.-L., and Durand, I.: Large scale circulation over and around the Kerguelen Plateau, Deep-Sea Res.Pt. II, 55, 566-581, 2008.

Park, Y.-H., Durand, I., Kestenare, E., Rougier, G., Zhou, M., d'Ovidio, F., Cotté, C., and Lee, J.-H.: Polar Front around the Kerguelen Islands: An up-to-date determination and associated circulation of surface/subsurface waters, J. Geophys. Res.Oceans, 2169-9291, doi:10.1002/2014JC010061, 2014a

Park, Y.-H., Lee, J.-H., Durand, I., and Hong, C.-S.: Validation of the Thorpe scale-derived vertical diffusivities against microstructure measurements in the Kerguelen region, Biogeosciences Discuss., 11, 12137-12157, doi:10.5194/bgd-11-12137-2014, 2014b.

Planchon, F., Ballas, D., Cavagna, A.-J., Bowie, A. R., Davies, D., Trull, T., Laurenceau, E., Van Der Merwe, P., and Dehairs, F.: Carbon export in the naturally iron-fertilized Kerguelen area of the Southern Ocean based on the 234Th approach, Biogeosciences Discuss., 11, 15991-16032, doi:10.5194/bgd11-15991-2014, 2014.

Pollard, R., Sanders, R., Lucas, M., and Statham, P.: The Crozet Natural Iron Bloom and Export Experiment (CROZEX), DeepSea Res.-Pt. II, 54, 1905-1914, 2007.

Popp, B. N., Kenig, F., Wakeham, S. G., Laws, E. A., and Bidigare, R. R.: Does growth rate affect ketone unsaturation and intracellular carbon isotopic variability in Emiliania huxleyi?, Paleoceanography, 13, 35-41, 1998a.
Popp, B. N., Laws, E. A., Bidigare, R. R., Dore, J. E., Hanson, K. L., and Wakeham, S. G.: Effect of phytoplankton cell geometry on carbon isotopic fractionation, Geochim. Cosmochim. Ac., 62, 69-77, 1998b.

Popp, B. N., Trull, T., Kenig, F., Wakeham, S. G., Rust, T. M. Tilbrook, B., Griffiths, F. B., Wright, S. W., Marchant, H. J., Bidigare, R. R., and Laws, E. A.: Controls on the carbon isotopic composition of Southern Ocean phytoplankton, Global Biogeochem. Cy., 13, 827-843, 1999.

Queguiner, B.: Biogenic silica production in the Australian sector of the Subantarctic Zone of the Southern Ocean in late summer 1998, J. Geophys. Res., 106, 31627-31636, 2001.

Queguiner, B.: Iron fertilization and the structure of planktonic communities in high nutrient regions of the Southern Ocean, Deep-Sea Res.-Pt. II, 90, 43-54, 2013.

Quéroué, F., Sarthou, G., Planquette, H. F., Bucciarelli, E., Chever, F., van der Merwe, P., Lannuzel, D., Townsend, A. T., Cheize, M., Blain, S., d'Ovidio, F., and Bowie, A. R.: High variability of dissolved iron concentrations in the vicinity of Kerguelen Island (Southern Ocean), Biogeosciences Discuss., 12, 231-270, doi:10.5194/bgd-12-231-2015, 2015.

Ragueneau, O., Schultes, S., Bidle, K., Claquin, P., and Moriceau, B.: Si and $\mathrm{C}$ interactions in the world ocean: Importance of ecological processes and implications for the role of diatoms in the biological pump, Global Biogeochem. Cy., 20, GB4S02, doi:10.1029/2006GB002688, 2006.

Rau, G. H., Teyssie, J.-L., Rassoulzadegan, F., and Fowler, S. W.: $13 \mathrm{C} / 12 \mathrm{C}$ and $15 \mathrm{~N} / 14 \mathrm{~N}$ variations among size fractionated marine particles: implications for their origin and trophic relationships., Mar. Ecol. Prog. Ser., 59, 33-38, 1990.

Rau, G. H., Riebesell, U., and Wolf-Gladrow, D.: A model of photosynthetic ${ }^{13} \mathrm{C}$ fractionation by marine phytoplankton based on diffusive molecular $\mathrm{CO}_{2}$ uptake, Mar. Ecol. Prog. Ser., 133, 275285, 1996.

Rau, G. H., Riebesell, U., and Wolf-Gladrow, D.: $\mathrm{CO}_{2 \mathrm{aq}}$-dependent photosynthetic ${ }^{13} \mathrm{C}$ fractionation in the ocean: A model versus measurements, Global Biogeochem. Cy., 11, 267-278, 1997.

Redfield, A. C., Ketchum, B. H., and Richards, F. H.: The influence of organisms on the composition of seawater, in: The Sea, edited by: Hill, M. N., Inter-Science, New York, 26-77, 1963.

Sanial, V., van Beek, P., Lansard, B., Souhaut, M., Kestenare, E., d'Ovidio, F., Zhou, M., and Blain, S.: Use of Ra isotopes to deduce rapid transfer of sediment-derived inputs off Kerguelen, Biogeosciences Discuss., 11, 14023-14061, doi:10.5194/bgd11-14023-2014, 2014.

Savoye, N., Trull, T. W., Jacquet, S. H. M., Navez, J., and Dehairs, F.: Th-234-based export fluxes during a natural iron fertilization experiment in the Southern Ocean (KEOPS), Deep-Sea Res.-Pt. II, 55, 841-855, doi:10.1016/j.dsr2.2007.12.036, 2008.

Schulz, K. G., Zondervan, I., Gerringa, L. J. A., Timmermans, K. R., Veldhuis, M. J. W., and Riebesell, U.: Effect of trace metal availability on coccolithophorid calcification, Nature, 430, 673676, 2004.

Schulz, K. G., Rost, B., Burkhardt, S., Riebesell, U., Thoms, S., and Wolf-Gladrow, D.: The effect of iron availability on the regulation of inorganic carbon acquisition in the coccolithophore Emiliania huxleyi and the significance of cellular compartmentation for stable carbon isotope fractionation, Geochim. Cosmochim. Ac., 71, 5301-5312, 2007. 
Smetacek, V.: Role of sinking in diatom life-history cycles: ecological, evolutionary and geological significance, Mar. Biol., 84, 239-251, 1985.

Smetack, V.: Diatoms and the silicate factor, Nature, 391, 224-225, 1998.

Sokolov, S. and Rintoul, S. R.: Circumpolar structure and distribution of the Antarctic Circumpolar Current fronts: 1. Mean circumpolar paths, J. Geophys. Res., 114, C11018, doi:10.1029/2008JC005108, 2009.

Sweeney, C., Hansell, D. A., Carlson, C. A., Codispoti, L. A., Gordon, L. I., Marra, J., Millero, F. J., Smith, W. O., and Takahashi, T.: Biogeochemical regimes, net community production and carbon export in the Ross Sea, Antarctica, Deep-Sea Res.-Pt. II, 47, 3369-3394, 2000.

Syvaranta, J. and Rautio, M.: Zooplankton, lipids and stable isotopes: importance of seasonal, latitudinal, and taxonomic differences, Can. J. Fish. Aquat. Sci., 67, 1721-1729, 2010.

Takeda, S.: Influence of iron availability on nutrient consumption ratio of diatoms in oceanic waters, Nature, 393, 774-777, 1998.

Tortell, P. D., Payne, C., Gueguen, C., Li, Y., Strzepek, R., Boyd, P., and Rost, B.: Uptake and assimilation of inorganic carbon by Southern Ocean phytoplankton, Limnol. Oceanogr., 53, 12661278, 2008.

Tremblay, L., Caparros, J., Leblanc, K., and Obernosterer, I.: Origin and fate of particulate and dissolved organic matter in a naturally iron-fertilized region of the Southern Ocean, Biogeosciences, 12, 607-621, doi:10.5194/bg-12-607-2015, 2015.
Trull, T. W. and Armand, L.: Insights into Southern Ocean carbon export from the delta $\mathrm{C}-13$ of particles and dissolved inorganic carbon during the SOIREE iron release experiment, Deep-Sea Res.-Pt. II, 48, 2655-2680, doi:10.1016/s0967-0645(01)000133, 2001.

Trull, T. W., Davies, D., and Casciotti, K.: Insights into nutrient assimilation and export in naturally iron-fertilized waters of the Southern Ocean from nitrogen, carbon and oxygen isotopes, Deep-Sea Res.-Pt. II, 55, 820-840, doi:10.1016/j.dsr2.2007.12.035, 2008.

van der Merwe, P., Bowie, A. R., Quéroué, F., Armand, L., Blain, S., Chever, F., Davies, D., Dehairs, F., Planchon, F., Sarthou, G., Townsend, A. T., and Trull, T.: Sourcing the iron in the naturally-fertilised bloom around the Kerguelen Plateau: particulate trace metal dynamics, Biogeosciences Discuss., 11, 1338913432, doi:10.5194/bgd-11-13389-2014, 2014.

Wada, E. and Hattori, A.: Nitrogen isotope effects in the assimilation of inorganic nitrogenous compounds by marine diatoms, Geomicrobiol. J., 1, 85-101, 1978.

Wang, X., Matear, R. J., and Trull, T. W.: Nutrient utilization ratios in the Polar Frontal Zone in the Australian sector of the Southern Ocean: a model, Global Biogeochem. Cy., 17, 1009, doi:1010.1029/2002GB001938, 2003.

Weiss, R. F.: Carbon dioxide in water and seawater: the solubility of a non-ideal gas, Mar. Chem., 2, 203-215, 1974. 